\title{
LA BIBLIOTECA DE PEDRO SALINAS
}

\author{
Juana María González García
}

\begin{abstract}
Pedro Salinas' personal library prior to the Spanish Civil War has so far remained almost unknown for both researchers and specialists dealing with his literary works. Preserved by the Cervantes Institute of Secondary School in Madrid, this group of books has however arose great interest. A catalogue of his personal books is contained in this work; this is the result of very slow and accurate classification work and further study of the texts as well as the appropriate thoughts on its history and characteristics.
\end{abstract}

KEY WORDS: Pedro Salinas; Library; Spanish Civil War; Catalogue.

En su relato La Biblioteca de Babel Jorge Luis Borges (2006) definía el universo como una gran biblioteca infinita. El autor se refería así al empeño de tantos hombres en la Historia por crear un lugar que contuviese todos los libros existentes, todo el conocimiento humano. En un tiempo en el que las técnicas digitales e informáticas empiezan a plantear la posibilidad efectiva de alcanzar este sueño, el texto del maestro argentino ha cobrado su más plena actualidad. A lo largo de los siglos se han ido creando distintos emplazamientos e instituciones donde acumular el saber. Desde el Antiguo Egipto y las míticas bibliotecas griegas de Alejandría y Pérgamo, los tesoros de la cultura y la ciencia han ido conservándose con auténtico celo. La posesión material de libros se convirtió en una manera de expresar su apropiación intelectual y respondía a un deseo imperioso del hombre de perpetuar la memoria de sus antecesores.

Contra lo que pudiera parecer, sin embargo, la biblioteca no es un espacio muerto o cerrado, sino "le thêatre d'une alchimie complexe où, sous l'effect de la lecture, de l'écriture et de leur interaction, se libèrent les forces, les mouvements de la pensée" (Baratin, 1996, 11). La biblioteca conserva así la memoria de los recorridos y navegaciones que la han atravesado (D'Izoio, 2001, 12-13), de los modos de utilización, de comprensión de aquellos

\section{THE LIBRARY OF PEDRO SALINAS}

RESUMEN: La biblioteca personal del poeta Pedro Salinas previa a la Guerra Civil española, ha permanecido prácticamente desconocida hasta el momento para los investigadores y estudiosos de su obra creativa. Conservada entre el fondo documental del Instituto madrileño de Secundaria Cervantes, este conjunto de libros tiene, sin embargo, un gran interés. En este trabajo se publican tanto el catálogo de libros del poeta, resultado de una lenta tarea de clasificación y estudio de los textos así como las convenientes reflexiones en torno a su historia y caracteristicas.

PALABRAS CLAVE: Pedro Salinas; Biblioteca; Guerra Civil española; Catálogo.

que se apropian de su contenido (Chartier, 2005), por lo que resulta una fuente de información importante para lo que actualmente conocemos con el término de "historia cultural" (Ory, 2004).

El caso de las colecciones personales es especialmente interesante a estos efectos. Si reunir libros puede convertirse simplemente en una manera de demostrar la capacidad adquisitiva de quien ostenta determinada posición social, la biblioteca de un "auténtico lector", de un escritor en este caso, está en estrecha relación con sus prácticas culturales, con sus hábitos como creador, pero sobre todo "con los valores que le mueven y con el uso que a la postre hace con su propia obra" (Chica, 1999, 13). Una sala de una biblioteca está configurada, pues, por una estructura, por unas "categorías artificiales" que responden a una lógica en la que todo se define según el sitio que ocupa. Ahondar en ella no sólo nos facilita una comprensión funcional de la misma, sino que conforma el paisaje respecto al cual el lector en cuestión reconstruye el sentido del texto. Además, y como afirmaba el escultor Juan Bordes:

[...] el principal motor del creador es su intuición, y esa fuerza generadora no se alimenta precisamente del conocimiento que proviene de un estudio sistemático. Por eso [...] una colección que pertenezca a un creador a veces 
puede desligarse de su carácter funcional e intelectual e interpretarse como un acto creativo más (Bordes, 2006, 359).

Con todo, a pesar de que existe una relación, más o menos intensa, entre las ideas artísticas de un creador y su colección personal de libros, la posesión de una serie de títulos no siempre está reñida con este tipo de motivaciones. En toda colección puede haber títulos que jamás se leyeron, textos que el autor nunca supo que tenía o volúmenes que quedaron olvidados en la estantería y que no se utilizaron jamás. De la misma manera puede haber libros determinantes para la obra de un artista que por diversas circunstancias no se encuentren hoy en su colección o que, incluso, jamás formaran parte de ella: "un inventario no tiene por qué representar todos los libros que una persona ha poseído en su vida, ni tampoco todos los libros que podía haber leído, ni tenemos que pensar que leía todos los libros que poseía" (Dadson, 1998, 25). Existen, en este sentido, diferencias fundamentales entre el coleccionista y el lector de libros. El primero no entra en contacto verdaderamente con los textos, pues en general no los lee. El segundo, sin embargo, los hace suyos y los reinterpreta, convirtiendo su biblioteca en un espacio único y original, en una fuente documental indispensable para conocer sus preferencias intelectuales y literarias.

Una aproximación científica a la colección de un autor pasa, pues, por tratar de recopilar todos los datos que ayuden a determinar, en la medida de lo posible, si el libro en cuestión se leyó o no, con el fin de facilitar, no sólo una aproximación a los condicionantes y variables implicados en la configuración del sentido del texto (Bourdieu, 2002), sino de valorar los procesos de incorporación de dichos materiales. Un elemento fundamental, a estos efectos, son las anotaciones 0 indicaciones que el lector en cuestión introduce en los volúmenes, es decir, sus marcas de lectura. Tal como indicaba Magdalena Rigual Bonastre, aparte de los datos de edición, "el libro puede ofrecer también otras fuentes de interés como presentar en los márgenes de sus páginas los sellos de las bibliotecas de donde podian haber sido sustraídos, o tejuelos o ex-libris que revelan la creación del artista y algún rasgo característico del propietario [...]" (Rigual Bonastre, 2000, 71). Los libros ofrecen así una información adicional que complementa la que se deriva única y exclusivamente del texto. Además, y como ocurre con la colección personal de Pedro Salinas, este tipo de información es básica, en muchas ocasiones, para la reconstrucción de su contenido y, en casos más extremos, de su historia.

Las bibliotecas son, entre los bienes culturales, objetos susceptibles de manipulaciones ideológicas, pues pueden ser deformadas y físicamente mutiladas $y$, en los casos más graves, destruidas. El caso de la biblioteca del poeta madrileño no es, en este sentido, sino una muestra más de las consecuencias devastadoras de la Guerra Civil sobre el patrimonio cultural español y uno de los ejemplos más peculiares con respecto a su preservación.

Conservada en la actualidad en ocho armarios del Instituto de Enseñanza Secundaria Cervantes, los libros del poeta han permanecido hasta el momento prácticamente desconocidos para los investigadores y estudiosos de su obra creativa. Como excepción podemos citar algunos trabajos menores como el capítulo dedicado a la colección del autor en la tesis doctoral de Guillem Vallejo Fores, El tema mitológico en la poesía de Pedro Salinas (1996)', o el reciente artículo de Juan María Marín Martínez, catedrático jubilado de lengua y literatura del propio IES Cervantes, publicado en la revista escolar del Centro (Marín Martínez, 2008 , 9). En ellos se reúnen algunos datos sobre la historia de esta biblioteca, así como las posibles circunstancias de su llegada al Cervantes, aunque se parte de la hipótesis de que todos ellos pertenecieron al poeta. El Centro, por su parte, posee un inventario de lo que hasta hoy se ha considerado "legado de Salinas" pero, a pesar del esfuerzo e interés de su profesorado y bibliotecarios, éste tiene deficiencias importantes que lo hacen inservible. En este capítulo me ocuparé, pues, de presentar mi propio estudio y catálogo de lo que hasta hoy se ha considerado como la muestra más importante de la biblioteca del autor hasta 1936, con la idea de resumir todos los datos que se conocen acerca de su configuración e historia y aclarar ciertas cuestiones sobre su contenido que podrían resultar de interés.

Relacionado con mi trabajo sobre los pedidos de Pedro Salinas a su cuñado León Sánchez Cuesta, este apartado quería cubrir una laguna en los estudios sobre el autor que enlaza con la investigaciones del proyecto CEIMES "Ciencia y educación en los institutos madrileños de enseñanza secundaria a través de su patrimonio cultural" 
(S2007/HUM-0512), que lleva a cabo el Instituto de Historia del Consejo Superior de Investigaciones Científicas (CSIC) y el Centro Interuniversitario MANES de la UNED (Universidad Internacional de Educación a distancia) con la financiación de la Comunidad de Madrid, bajo la dirección de Leoncio López Ocón y Gabriela Ossenbach². Los objetivos del proyecto se centran en dos puntos fundamentalmente: 1) Recuperar y reactivar el patrimonio educativo del período histórico 1837-1936 a través de su encarnación material en diversas colecciones científicas, bibliográficas; en laboratorios y gabinetes como espacios experimentales; en edificios y patrimonio inmobiliario como representación física de las ideas; en un conjunto de actores y protagonistas que concibieron y desarrollaron esos conceptos; 2) Trasladar dicho material a nuestros días para los usos didácticos y pedagógicos que la educación contemporánea determine. Mi interés por el proyecto surgió, pues, cuando, tras elaborar un catálogo nuevo de la colección del poeta, me encontré con una gran variedad de sellos y marcas en los volúmenes que acababan por conformar una biblioteca mucho más compleja de lo que se pensaba en un principio.

Tanto los años que duró la Guerra Civil como el período posterior de consolidación del régimen franquista afectaron significativamente a los fondos bibliográficos y de material educativo de los centros escolares, en lo que el Instituto de Secundaria Cervantes no fue una excepción. El caos desatado en el pais provocó la pérdida de gran cantidad de bienes culturales, tanto personales como privados, y en muchos casos su destrucción. La aparición en la colección de títulos que cronológicamente no pudieron pertenecer al autor, así como ejemplares dedicados a otras personalidades y escritores, hicieron que me planteara la necesidad de elaborar una historia de la biblioteca que explicase esta amalgama de procedencias, así como el momento de su incorporación al fondo bibliográfico del Instituto, con la idea de poder seleccionar aquellos volúmenes que, por sus características, pudieron pertenecer verdaderamente al poeta.

En este sentido consideré que lo más sencillo, y dado que a pesar de todo la biblioteca conservaba un gran número de obras del poeta, puesto que estaban dedicadas, era enfocar la investigación como un trabajo de selección de los libros que pudieron pertenecer al autor madrileño y a partir de ahí elaborar las conclusiones pertinentes respecto a los que no lo fueran. Los distintos seminarios y charlas promovidos por el grupo de investigación del proyecto CEIMES fueron entonces una muy buena ocasión, a este respecto, para intercambiar información con otros especialistas en el campo que me ayudaron considerablemente a progresar en mi trabajo. En todo caso, no queda mucha documentación respecto a estas cuestiones, por lo que he de advertir que la mayor parte de los datos contenidos en las investigaciones hechas hasta el momento, y en la mía propia, provienen de la "tradición oral". Sin embargo, un estudio pormenorizado de la historia del centro y de los ex-libris que aparecen en los volúmenes da pistas interesantes acerca de lo que pudo haber sucedido con la colección y, en este sentido, aproximarnos con mayor certeza a lo que sucedió en realidad.

La historia de las peripecias de esta biblioteca comienza en 1936 cuando, tras el estallido de la Guerra Civil, Pedro Salinas se traslada a Estados Unidos, donde había sido previamente invitado por Wellesley College (Massachusetts) para cubrir una vacante durante el curso académico 19361937. El poeta y su familia se encontraban en Santander, donde Salinas participaba en los cursos de la Universidad Internacional de Verano de la que era Secretario. Al estallar la guerra, sus bienes y posesiones quedaron en Madrid al cuidado de algunas personas de confianza, quienes a pesar de los esfuerzos no pudieron evitar que el piso fuera ocupado por familias de evacuados que huian de los frentes de batalla. El riesgo para sus pertenencias era por tanto inminente y aunque los exiliados esperaban que el conflicto se resolviera rápidamente, la prolongación de la Guerra terminó por acabar con las esperanzas de regresar al pais y con ellas de recuperar sus bienes.

La providencial visita en 1938 de la Junta de Incautación del Tesoro Artístico, entonces a cargo de Antonio Rodríguez Moñino, consiguió poner a salvo algunos de los libros del poeta que, como ocurrió con tantas otras colecciones particulares, fueron trasladados a la Biblioteca Nacional como medida preventiva. Sin embargo, ningún miembro de la familia tuvo noticia de este suceso hasta muchos años después, cuando, tras la reciente exposición Biblioteca en Guerra organizada por la Biblioteca Nacional en 2005, se sacó a la luz la nota que redactó uno de los milicianos que realizó la visita y que reproducimos también aquí: 
SALINAS, Pedro. Príncipe de Vergara, 76 (2). Biblioteca. Interesan sobre todo colección de libros ingleses modernos. El piso tiene evacuados y convendría recogerlos pronto.

Visitada en 10-8-38. Tres familias de evacuados. Quedan bastantes libros y tres cuadritos. Se recogerá todo en cuanto haya camioneta.

Recogida la biblioteca y objetos en 11-8-37. Depositado bibl. en la B.N. Sala de Carlos III y los cuadros y objetos en el local de la Junta.

(Según informa el evacuado teniente Reyes, que firma el acta, todos los muebles, ropas, parte de los libros, etc., se los llevó una célula comunista, que dejó recibo al portero) ${ }^{3}$.

Con esto debemos suponer que los libros que quedaban en el piso de los Salinas Ilegaron a la Biblioteca Nacional entre 1937 y 1938 donde permanecieron al menos durante dos años. Se desconocen no obstante las circunstancias en que esta supuesta "célula comunista" se apropió de algunos libros del autor. Jaime Salinas, hijo del poeta, tan sólo menciona en sus Memorias la visita de varias personas, entre las que se cita a Dámaso Alonso, quiénes, al parecer, fueron a recoger al piso algunos documentos comprometedores para su amigo Pedro (Salinas, 2003, 90-92). A su vez, la tradición oral inculpa a Carmen Conde y a su marido Antonio Oliver Belmás, profesor de Lengua y Literatura española en el Instituto Cervantes años más tarde, de la sustracción de algunos de los volúmenes del poeta, aunque no existe documentación a este respecto.

Con todo, y después de diferentes indagaciones, se ha optado por pensar que los libros que se conservan hoy en la biblioteca del Instituto Cervantes son los que Rodríguez Moñino y su piadoso grupo de colaboradores llevaron a la Biblioteca Nacional para su protección. Tras la Guerra, los libros incautados por la Junta del Tesoro Artístico eran devueltos a sus respectivos propietarios, a no ser que, por imposibilidad de entrega, quedaran en la propia Biblioteca Nacional en un registro aparte ${ }^{4}$.

Sin embargo, no todos corrieron la misma suerte. Las represalias tomadas contra el bando vencido generaron toda suerte de atropellos e injusticias, por lo que muchas de esas colecciones fueron, al parecer, incorporadas al fondo de la Biblioteca Nacional sin distinción de propietarios, 0 , en su caso, donadas a otros centros, a los institutos de educación secundaria por ejemplo, para restituir sus bibliotecas y recuperar parte del material docente extraviado. Lo mismo ocurrió supuestamente con otras instituciones y organismos republicanos suprimidos o transformados durante el franquismo, como la Junta de Intercambio y Adquisición de Libros, el Patronato de Misiones Pedagógicas o la Residencia de Estudiantes. Los fondos bibliográficos de estos centros fueron seleccionados y repartidos, cuando no destruidos, con el fin de recuperar rápidamente el normal funcionamiento del país.

Hemos de pensar que la biblioteca de Pedro Salinas debió de correr esta misma suerte. A pesar de que no he podido localizar documentos que certifiquen la salida de los libros del poeta de la Biblioteca Nacional, así como ningún tipo de listado o registro de su entrada en el Cervantes, la complejidad de la historia del Centro, así como la variedad de sellos y ex-libris en los volúmenes que conforman la colección, parecen indicar que éstos llegaron al Centro, junto con libros de otras instituciones y particulares, como una donación del Estado para restituir sus fondos. Sin embargo, la documentación respecto a estas actividades y movimientos se ha perdido o destruido en su mayoría, dejando un margen de incertidumbre en el que sólo caben conjeturas.

El Instituto de Secundaria Cervantes era sucesor de un Instituto Local Femenino llamado Infanta Beatriz que había sido creado en 1929 (Instituto..., 1982). Con la llegada de la República el Centro cambió su nombre por el de Cervantes y se estableció en 1934 en un palacete en la calle Prim, número 3, muy próximo a la Biblioteca Nacional, residencia hasta entonces de la condesa del Villar, donde permanecerá hasta 1950.

Al estallar la Guerra Civil el Instituto fue cerrado. Otros centros, sin embargo, como los institutos Lagasca, Lope de Vega y Pérez Galdós, continuaron funcionando y se convirtieron en depositarios de gran parte del material escolar y docente del resto de centros para evitar su pérdida o destrucción.

Entre 1936 y 1939 la sede del Cervantes fue ocupada por distintas organizaciones y grupos. Tras estallar la Guerra, en septiembre, se instaló en el edificio la Federación Universitaria Escolar (FUE), que permanecerá alli durante 
unos meses. En este período desaparecieron gran parte de los libros de nombramientos de profesores, calificación de asignaturas, documentación académica, etc., además de enseres, máquinas de escribir y útiles de laboratorio que se trasladaron a los Institutos de secundaria que estaban funcionando.

Durante los primeros meses de 1937 la FUE compartió los locales con una organización denominada "Alerta", de la que no existen prácticamente datos, aunque ya en el mes de abril el edificio fue ocupado en su práctica totalidad por las Compañías 105 y 106 de la Guardia de Asalto. Asimismo, en el mes de mayo de ese mismo año se produjo un grave bombardeo que provoca el abandono del edificio, que volverá a ocuparse en octubre por el Batallón de Redes Artilleras, llamado posteriormente de Transmisiones del Ejército del Centro. Además, en diciembre se establecerá allí mismo la Sección de Acuartelamiento del Ministerio de Defensa que se llevó casi todo el material didáctico al Instituto Lope de Vega recuperado, supuestamente, en su totalidad en 1939.

En enero de 1938 se aloja en el edificio el 42 Batallón de Fortificaciones. En abril se hace cargo de él la Liga Nacional de Mutilados de Guerra, que se ocupa de restaurarlo y amueblarlo y que permite el acceso al personal que aún estaba vinculado al instituto. Esto facilitó después la recuperación de la actividad académica del centro pues, gracias al trabajo de su interventor Antonio Mingarro Satue, se recuperará rápidamente todo el material docente y vuelven a retomarse las clases.

Es de suponer que la biblioteca de Pedro Salinas Ilegaria al Centro en esas mismas circunstancias. Desalojados de la Biblioteca Nacional, los libros debieron llegar al Cervantes dentro de un fondo común de obras donadas para empleo de los estudiantes. La conciencia literaria de Antonio Mingarro le llevó a mantener separados este conjunto de libros que, a pesar de disgregaciones y pérdidas, permanece reunido en la actualidad.

Tras varios años de funcionamiento en la calle Prim, el Instituto se traslada en 1950 a la sede del Colegio Alemán en Madrid, donde permanece hasta 1960, fecha en que se estableció en su sede actual. De aquí deben de proceder muchos de los libros marcados con el sello del Colegio que pudieron incorporarse a la colección en aquellos años.
Además en 1991 el Instituto sufre una serie de reformas y hubo que vaciarlo en su totalidad, con el consiguiente movimiento de sus fondos bibliográficos ${ }^{5}$.

Con esto quiero llamar la atención sobre el hecho de que a pesar del cuidado del personal docente y administrativo, no es del todo improbable que estos traslados y movimientos fueran la causa principal de que los libros del poeta se mezclaran con los de otras procedencias, constituyendo el actual legado que queda en el centro. El resultado es una biblioteca heterogénea en procedencias y cronología que sin duda, y a pesar de las dificultades que conlleva para el investigador, es una fuente de información importante en lo que se refiere a la historia del centro. Mi tarea consistió, pues, esencialmente en elaborar una serie de criterios de selección, además de un catálogo nuevo, que ayudaran a determinar qué libros fueron propiedad del autor y cómo y cuándo se mezclaron con los demás.

El primer aspecto a tener en cuenta en este sentido fue la cronología. Como se dijo al principio, Pedro Salinas dejó en España todos aquellos libros que no pudo llevarse consigo en 1936, por lo que las obras publicadas con una fecha posterior a ésta no podían pertenecer a su biblioteca. Éstos aparecen sellados normalmente por instituciones franquistas, o por el Colegio Alemán, donde el Instituto estableció su sede en los años 50 . El investigador podrá encontrar a este respecto el sello de la nueva Junta de Intercambio y Adquisición de Libros y Revistas que volvió a funcionar en España una vez terminada la Guerra, y cuatro sellos diferentes del Instituto Cervantes. No se conserva, a este respecto, el sello republicano del centro en ninguno de los volúmenes, aunque sí algunos marcados por el primitivo sello del IES Infanta Beatriz.

En los volúmenes aparecían, sin embargo, sellos de instituciones culturales y educativas republicanas que parecían indicar que, en esta colección, se contenían un gran número de libros de dichas entidades una vez fueron suprimidas por el nuevo régimen. Entre los sellos que aparecen habría que destacar pues los de la Residencia de Niños, la Junta para Ampliación de Estudios, los Institutos republicanos de Educación Secundaria Quevedo y Pérez Galdós, la Residencia de Estudiantes o la Junta de Intercambio y Adquisición de Libros. Además, un gran número de ellos contienen sellos de la Oficina de Adquisición de Libros de Valencia y Cultura Popular, instituciones creadas 
durante los años de la Guerra Civil para la protección y fomento de la lectura en el bando republicano. Dichas entidades asumieron las funciones de la Junta de Intercambio y Adquisición de Libros y del Patronato de Misiones Pedagógicas en cuestiones bibliotecarias, ocupándose del suministro de las bibliotecas públicas y escolares y se encargaron de coordinar todas las manifestaciones culturales de los partidos políticos, sindicatos y agrupaciones culturales deportivas organizando una red de bibliotecas circulantes que fueron repartidas a batallones, frentes de batalla y hospitales. Entre ellos se encontraba la Liga española de Mutilados de Guerra, con sede temporal en nuestro Instituto (Martínez Rus, 2003). Los libros parecen haber pasado asi de unas instituciones a otras como parte de un fondo bibliográfico circulante en los que iban quedando marcas y sellos. El número de ejemplares con estas caracteristicas dentro de la colección es muy llamativo, en lo que sin duda tienen mucho que ver las propias peripecias de la historia del centro.

La aparición de marcas y sellos de otros centros educativos, por otra parte, no es de extrañar. Como mencionamos más arriba, el material pedagógico y bibliográfico de los institutos de secundaria se trasladó de unas sedes a otras para evitar su pérdida y deterioro, con lo que existen muchas posibilidades de dispersión y confusión en su reparto. Es el caso de los sellos del Instituto Quevedo o Pérez Galdós, antes mencionados. Asimismo, hice caso omiso de los papeles, fichas, cartas, etc., que aparecen entre las páginas de los libros pues pudieron introducirse en cualquier momento y dificultaban el proceso de selección de los textos. Descarté en este caso todos aquellos libros dedicados a otras personas o entidades como los firmados por José Jiménez Oliver, Manuel Astor, Nazario Olivera del Río o Antonio Jaén, de quiénes se conservan varios volúmenes en esta colección. Además existen algunos ejemplares con dedicatorias a Óscar Esplá, Juan Chabás, Luis Araquistain o Antonio Machado, aunque no es una representación muy significativa. En muchos de los volúmenes aparecen asimismo marcas de clasificación bibliotecaria como números, estanterías, signaturas, pero que, dada su variedad, es casi imposible determinar de dónde proceden.

En resumen, dada la complejidad de la biblioteca, opté por seleccionar como libros seguros de Salinas sólo aquellos volúmenes dedicados al poeta nominalmente. Además in- cluí en este grupo aquellos ejemplares con dedicatorias a instituciones cercanas al poeta, como el Centro de Estudios Históricos o la Universidad de Sevilla. No consideré, sin embargo, ninguno de los libros sellados por las instituciones republicanas mencionadas, entendiendo que, dado el volumen de los ejemplares con dichas marcas, nunca formaron parte de la biblioteca del poeta.

Sin embargo, por miedo a elaborar unos criterios demasiado tajantes, he considerado como "posibles de Salinas" bastantes libros, entre ellos algunos editados a finales del siglo XIX, que, por cuestiones de autoria o intereses personales, no era difícil imaginar como suyos. Comprendo, en todo caso, que muchos de los incluidos en este grupo de probables pudieron no pertenecerle, pero no tenía datos que demostrasen lo contrario. A este respecto, procuré utilizar en algunas ocasiones la información que poseía de los pedidos del poeta a su amigo y librero León Sánchez Cuesta, lo que fue decisivo para determinar la procedencia de algunos de ellos.

Creo, pues, que la distribución de los libros en los ocho armarios de la colección puede quedar descrita del siguiente modo:

En el primer armario se conserva sobre todo un número considerable de ejemplares de la colección Clásicos Castellanos publicados por la editorial La Lectura. En ella tienen especial relevancia las obras completas de autores como Calderón de la Barca, Santa Teresa de Jesús, Jorge Manrique, José Zorrilla, Mateo Alemán, Fray Luis de León, San Juan de la Cruz o Miguel de Cervantes. Además, aparecen numerosos trabajos críticos y editoriales de autores reconocidos como Ramón Menéndez Pidal, Marcelino Menéndez Pelayo, Agustín Millares Carlo, Federico de Onís, José Fernández Montesinos o José Moreno Villa, con los que Salinas mantuvo una gran amistad. Por otra parte, se conserva también un número considerable de la colección Biblioteca de Autores Españoles, de la editorial M. Rivadeneyra, que, a pesar de estar editados a finales del siglo XIX, he decidido dar como del poeta. Entre los críticos más interesantes de esta colección pueden citarse a Juan Eugenio Hartzenbusch, Agustín Durán o Cayetano Rosell.

En general, y dadas las características de los textos, la mayor parte de los libros de este armario serían, pues, 
libros del poeta, a excepción de los marcados con el sello de IES Quevedo, que ocupan una buena parte del conjunto.

El segundo armario reúne algunos de los títulos dedicados al poeta nominalmente. Entre ellos pueden citarse obras de Jaime Torres Bodet, Saulo Torón, Ángel Vegué y Goldoní o Edmond Vandercammen. La mayor parte de los textos son obras completas e historias literarias que aparecen selladas frecuentemente por la Junta de Intercambio franquista. Cabe destacar, sin embargo, las primeras ediciones de algunos de los libros del poeta como Seguro azar o Amor en vilo, además de algunos donativos de estudiantes y particulares a otras instituciones. En este armario se encuentra la Historia General de las literaturas hispánicas, de Guillermo Díaz Plaja (1949) o algunos ejemplares de la Revista de Filología Española, además de una serie numerosa de obras editadas entre los años 50 y 60.

El armario tres contiene igualmente obras editadas en los años 40, 50 y 60, entre las que cabe destacar las de José María de Cossío o Antonio Vilanova. Además la colección conserva casi todos los tomos de las Obras completas de Marcelino Menéndez Pelayo, editadas en 1940 por el Consejo Superior de Investigaciones Científicas. Conviene señalar, sin embargo, algunas de las obras editadas con fecha anterior al año 36 que aparecen selladas como Donativos de la Junta de Intercambio y Adquisición de Libros y que no consideré del poeta. El conjunto viene a completarse con un gran número de libros marcados con el sello del IES republicano Pérez Galdós, así como por el Patronato de Misiones Pedagógicas, Milicias de la cultura, Oficina de Adquisición de Libros de Valencia y la Liga de Mutilados de Guerra. Con todo, aparecen algunos volúmenes dedicados al poeta, que son los únicos que pertenecen a su colección, entre los que destacan obras de Claudio de la Torre, Marcel Bataillon, José Bergamín, Mariano Brull, Alfonso Reyes o Rogelio Buendía.

Por el contrario, el armario cuatro, conserva un gran número de obras dedicadas al poeta. Cabe destacar, en este sentido, algunos títulos de Marcel Proust, John Dos Passos, Henry de Montherlant o Jean Cassou. Este armario contiene, pues, la mayor parte de la representación extranjera de la colección del poeta, sobre todo la francesa. Sobresalen además, los volúmenes de ensayos dedicados a la psicología como L'année psycologique de Henri Piéron - L'evolution de l'Occultisme et la Sience d'adjourd'hui de Pierre Piob. El poeta conservó, asimismo, gran número de libros sobre Historia del arte y la literatura, entre los que pueden mencionarse los trabajos de Maurice Raynal, Anthologie de la Peinture en France, Michel Dragomirescou, La Science de la Littérature o de Jean Thomas, Quelques aspects du Romantisme Contemporaine.

El armario once, por su parte, está repleto de poemarios de autores contemporáneos y conocidos del poeta como pueden ser Antonio Espina, Rafael Laffón o Gerardo Diego y la mayoría están dedicados. Existen, con todo, algunos volúmenes editados en los años cincuenta que, en este caso, no serian de Salinas. La mayor parte de los libros que se contienen en este armario pertenecieron, pues, al poeta.

En el armario doce se conserva un material para nada parecido al visto hasta ahora, pues hay muchas menos dedicatorias al poeta y aparecen constantemente los sellos del IES Pérez Galdós, la Junta de Intercambio y Adquisición de Libros Republicana y la Oficina de Adquisición de Libros de Valencia. El contenido del armario trece prosigue en esta línea, pues reúne un gran número de libros marcados como Donativos de la Junta de Intercambio, así como de Cultura Popular. Sin embargo hay un margen considerable de libros posibles del poeta que no carecen de interés, entre los que pueden contarse los volúmenes de José María Salaverría, José Ortega y Gasset, Eugenio Zamiatin o ejemplares de la revista Carmen. Se conservan además algunos de los ejemplares sellados por el Centro de Intercambio Intelectual Germano-Español, o Colegio Alemán. Por último, sobresale la gran representación de libros pertenecientes a la colección Universal, además de algún que otro ejemplar dedicado a otras personalidades y figuras del mundo intelectual.

El armario catorce, finalmente, conserva en su mayor parte una amplia selección de los volúmenes editados en la Colección Biblioteca Clásica de la Librería Sucesores de Hernando. Entre ellos destacan las obras de clásicos importantes como Homero, Virgilio o Cicerón, además de autores españoles como Quevedo o Cervantes, y ciertas antologías de líricos ingleses y americanos. A pesar de que parece poco probable que todos los libros de la colección hubieran pertenecido a Salinas, muchos están cerca de 
los intereses y posibles lecturas del poeta, y los he dado como suyos.

En conclusión, y vistos todos los datos, se podría decir que, el conjunto de libros considerado hasta ahora como legado de Pedro Salinas queda reducido en mi catálogo en casi un $50 \%$. Sólo 330 ejemplares pueden considerarse del poeta a ciencia cierta, esto es prácticamente un $20 \%$ del total, a los que habría que añadir otros 604 ejemplares probables. A pesar de todo, la colección tiene un interés formidable, no sólo porque contiene los pocos libros que han logrado salvarse de uno de los mejores poetas españoles del siglo XX, sino porque es un muestrario interesante de las políticas y medidas establecidas por el Gobierno franquista en materia bibliográfica una vez terminada la Guerra Civil. La colección contiene sin embargo pocos ejemplos de manuales o libros de texto usados en el instituto que pudieran dar información sobre el panorama educativo español anterior a 1936. La biblioteca que se conserva en el Cervantes está formada, esencialmente, por obras literarias y antologías con los que los alumnos debian poder completar los estudios y conocimientos adquiridos en clase.

El caso de la colección de este Instituto no es el único en este sentido. Hay Bibliotecas como ésta en el IES Cardenal Cisneros e Isabel la Católica, por sólo citar algunos, constituyendo un material importante para valorar el patrimonio educativo español de la primera mitad del siglo XX, así como de la propia historia del libro. El estudio y catalogación de los fondos de los diversos centros escolares madrileños facilitará en este sentido un conocimiento detallado de las medidas adoptadas por los distintos Gobiernos españoles en materia educativa y de las estrategias adoptadas para su implantación. Este trabajo da a conocer la parte de la biblioteca de Salinas guardada en este Instituto, en virtud de la selección explicada más arriba. El catálogo completo podrá consultarse próximamente, tanto en la edición de mi tesis doctoral, como en el propio Centro ${ }^{6}$.

\section{NOTAS}

1 El autor hace una selección de los libros que según él pudieron influir en el tratamiento del tema en la obra del autor.

2 http://www.ceimes.es/

3 La ficha aparece publicada en Biblioteca en Guerra, Catálogo de la exposición [Madrid, 15 de noviembre de 2005, 19 de febrero de 2006], ed. Blanca Calvo y Ramón Salaberria, Madrid, Biblioteca Nacional de España, 2005, p. 201.

4 Agradezco aqui las precisiones que Enrique Pérez Boyero, Jefe del Archivo de la Biblioteca Nacional de España, me hizo sobre el tema.

5 Agradezco aquí las precisiones de $\mathrm{Mi}-$ lagro Fernández y Fernández-Cuesta, profesora de Historia en el Instituto Cervantes.

Recibido: 10 de octubre de 2009

Aceptado: 20 de enero de 2010
6 Quisiera agradecer la ayuda y facilidades prestadas por parte del Ins- tituto Cervantes para la realización de este trabajo, concretamente a su director Luis Ferrero Carracedo y a la actual directora, Julia Pérez Gómez. También al Departamento de Lengua y Literatura del Centro que actualmente realiza distintas investigaciones sobre este legado bajo la dirección de José Carlos Menéndez Pérez y Pilar Gil Soler. No querría dejar de citar a Ramón Asquerino Fernández y Milagro Fernández y Fernández-Cuesta, cuyas aportaciones fueron determinantes para la orientación de este trabajo, así como a Pilar Merchán y Piedad Sánchez, encargadas de la biblioteca, Esteban Greciet García, primer corrector de este texto, y Fernando Agudo Vila, diseñador de la base de datos de libros que se presenta, con los que he pasado muchas horas de trabajo. A todos ellos, de verdad, muchas gracias. 
Baratin, M. y Christian, J. (1996): Le pouvoir des bibliothèques. La mémoire des livres en Occident, Paris, Albin Michel.

- (2001): Bibliothèques d'écrivains. Séminaire international, dir. Paolo D'Izoio et Daniel Ferrer, París, CNRS.

Bordes, J. (2006): "Coleccionar-crear", en Seminario de Archivos Personales, 26 a 28 de mayo de 2004, Madrid, Biblioteca Nacional.

Borges, J. L. (2006): "La Biblioteca de Babel", en Ficciones, Madrid, Alianza.

Bourdieu, P. (2002): Las reglas del arte: génesis y estructura del campo literario, Barcelona, Anagrama.
Chartier, R. (2005): El mundo como representación: estudios sobre historia cultural, trad. Claudia Ferrari, Barcelona, Gedisa.

Chica, F. (1999): El poeta lector. La biblioteca de Emilio Prados, La Sirena.

Dadson, Trevor J. (1998): Libros, lectores y lecturas. Estudios sobre biblioteca particulares del Siglo de Oro, Madrid, Arco Libros.

- (1982): Instituto de Bachillerato Cervantes. Miscelánea en su cincuentenario 1931-1981, coord. Juan Haro Sabater et alii, Madrid, Ministerio de Educación y Ciencia.

Marin Martínez, J. M. (abril de 2008): "El legado de Pedro Salinas", El ingenioso hidalgo, no. 12, Madrid, p. 9.
Martínez Rus, A. (2003): La política del libro durante la Segunda República. Socialización de la lectura, Gijón, Trea.

Ory, P. (2004): L'histoire culturelle, Paris, PUF.

Rigual bonastre, M. (2000): J. Martínez Ruiz, lector y bibliófilo, Alicante, Universidad de Alicante.

Salinas, J. (2003): Travesías: memorias (1925-1955), Barcelona, Tusquets.

Vallejo Fores, G. (1996): El tema mitológico en la poesía de Pedro Salinas, Tesis Doctoral, Universidad de Barcelona, Departamento de Filología Griega.

\section{CATÁLOGO DE LA BIBLIOTECA}

Álvarez Gato, Juan, Obras Completas, edición, introducción y notas de Jenaro Artiles Rodríguez, Madrid, CIAP, 1928, 215 págs. (Colección Los clásicos olvidados. Nueva Biblioteca de Autores Españoles, núm. 4)

Abril, Manuel, Canciones del corazón y de la vida, Madrid, Imprenta de la Revista de Archivos, 1906, 106 págs.

Abril, Manuel, Felipe Trigo. Exposición y Glosa de su vida, su filosofía, su moral, su arte, su estilo, Madrid, Renacimiento, 1917, 272 págs.

Abril, Manuel, Hacia la luz lejana, Madrid, Imprenta de Nuevo Mundo, 1914, 134 págs.

Acevedo Escobedo, Antonio, Sirena en el aula, México, s.n., 1935, 166 págs.

Ageleti Garriga, Jaume, Hostal de núvols, Barcelona, Altés, 1931, 66 págs.

Aguilar, Gaspar de, Fábula de Endimion y la luna, Madrid, Cruz y Raya, 1935, 43 págs. (Colección La rosa blanca, núm. 3)

Agustí, Ignasi, El veler, Barcelona, Altés, 1932, 62 págs.

Alas "Clarín", Leopoldo, El Señor y lo demás son cuentos, Madrid/Barcelona, Calpe, 1919, 222 págs. (Colección Universal)

Albalat, Antoine, Comment on devient écrivain, París, Librairie Plon, 1925, 280 págs.

Alcalá Galiano, Antonio, Recuerdos de un anciano, Madrid, Librería de la viuda de Hernando y Compañia, 1890, 545 págs. (Colección Biblioteca Clásica, núm. 8)
Alemán, Mateo, Guzmán de Alfarache, edición y anotación de Samuel Gili y Gaya, Madrid, Ediciones La Lectura, Vol. 4, 1929, 264 págs. (Colección Clásicos Castellanos, núm. 93)

Alemán, Mateo, Guzmán de Alfarache, edición y anotación de Samuel Gili y Gaya, Madrid, Ediciones La Lectura, Vol. 2, 1927, 293 págs. (Colección Clásicos Castellanos, núm. 83)

Alemán, Mateo, Guzmán de Alfarache, edición y anotación de Samuel Gili y Gaya, Madrid, Ediciones La Lectura, Vol. 1, 1926, 246 págs. (Colección Clásicos Castellanos, núm. 73)

Alonso, Dámaso, Poemas puros. Poemillas de la ciudad, Madrid, Galatea, 1921, 108 págs.

Altolaguirre, Manuel, Poesía, núm. 1, s.l., Imprenta de Manuel Altolaguirre, s.a.

Altolaguirre, Manuel, Soledades juntas, Madrid, Editorial Plutarco, 1931, 154 págs.

Álvarez del Vayo, Julio, Rusia a los doce años, Madrid, Espasa Calpe, 1929, 162 págs.

Álvarez Quintero, Serafín y Álvarez Quintero, Joaquín, Teatro Completo. 29. Comedias y Dramas. Cristalina. Concha limpia. Mi hermano y yo, Madrid, Imprenta Clásica Española, Tomo 29, 1928, 313 págs.

Amicis, Edmundo de, España. Impresiones de un viaje hecho durante el reinado de D. Amadeo I, trad. Cátulo Arroita, BarceIona, Casa Editorial Maucci, ¿1899?, 361 págs.

Andrés Álvarez, Valentín, Tararí. Farsa cómica en dos actos y un epílogo. Estrenada en el Teatro Lara de Madrid el 25 de spetiembre de 1929, Madrid, Revista de Occidente, 1929, 96 págs. (Colección Nova Novorum)

ARBOR CLXXXVI 744 julio-agosto [2010] 739-776 ISSN: 0210-1963 
Ángeles, Juan de los, Obras Misticas. Parte primera 1. Triunfos del amor de Dios (parte) 2. Diálogos de la Conquista del Reino de Dios 3. Manual de la vida perfecta 4. Lucha espiritual y amorosa entre Dios y el alma 5. Tratado de los soberanos misterios de Dios 6. De cómo el alma ha de tener siempre a Dios presente delante de sí 7. Libro primero del Vergel del ánima religiosa, anotadas y precedidas de una introducción bio/bibliográfica de Fr. Jaime Sala, Madrid, Bailly Bailliére, 1912, 574 págs. (Colección Los clásicos olvidados. Nueva Biblioteca de Autores Españoles, núm. 20)

Antología de la poesía argentina moderna 1900-1925, con notas biográficas y bibliográficas, ordenada por Julio Noé, Buenos Aires, Edición de nosotros, 1926, 603 págs.

Antología de líricos ingleses y angloamericanos, colección y colaboración de Miguel Sánchez Pesquera, Madrid, Librería de los sucesores de Hernando, Tomo 5, 1922, 366 págs. (Colección Biblioteca Clásica, núm. 248)

Antología de líricos ingleses y angloamericanos, colección y colaboración de Miguel Sánchez Pesquera, Madrid, Libreria de los sucesores de Hernando, Tomo 3, 1917, 359 págs. (Colección Biblioteca Clásica, núm. 241)

Antología de líricos ingleses y angloamericanos, colección y colaboración de Miguel Sánchez Pesquera, Madrid, Librería de los sucesores de Hernando, Tomo 2, 1916, 415 págs. (Colección Biblioteca Clásica, núm. 238)

Antología de líricos ingleses y angloamericanos, colección y colaboración de Miguel Sánchez Pesquera, Madrid, Librería de los sucesores de Hernando, Tomo 1, 1915, 421 págs. (Colección Biblioteca Clásica, núm. 234)

Antología de líricos ingleses y angloamericanos, colección y colaboración de Miguel Sánchez Pesquera, Madrid, Librería de los sucesores de Hernando, Tomo 7, 1924, 351 págs. (Colección Biblioteca Clásica, núm. 250)

Antología de poesías líricas españolas, escogidas y explicadas por Hellmuth Petriconi en colaboración con Wilhelm Michels, s.l., Max Niemeyer Verlag, Tomo 16, 1932, 109 págs. (Colección Sammlung Romanischer Übungstexte, núm. 18)

Antología de poetas líricos castellanos. Desde la formación del idioma hasta nuestros días, ordenada por Marcelino Menéndez Pelayo, Madrid, Librería de Perlado, Páez y Compañia. Sucesores de Hernando, Tomo 4, 1918, 384 págs. (Colección Biblioteca Clásica, núm. 171)

Antología de poetas líricos castellanos. Desde la formación del idioma hasta nuestros días, ordenada por Marcelino Menéndez Pelayo, Madrid, Librería de la viuda de Hernando y Compañía, Tomo 5, 1911, 436 págs. (Colección Biblioteca Clásica, núm. 188)
Antología de poetas líricos castellanos. Desde la formación del idioma hasta nuestros días, ordenada por Marcelino Menéndez y Pelayo, Madrid, Librería de los sucesores de Hernando, Tomo 1, 1924, 300 págs. (Colección Biblioteca Clásica, núm. 136)

Antología de poetas líricos castellanos. Desde la formación del idioma hasta nuestros días, ordenada por Marcelino Menéndez y Pelayo, Madrid, Librería de Perlado, Páez y Compañía. Sucesores de Hernando, Tomo 2, 1923, 304 págs. (Colección Biblioteca Clásica, núm. 149)

Antología de poetas líricos castellanos. Desde la formación del idioma hasta nuestros días, Madrid, Librería de Perlado, Páez y Compañía. Sucesores de Hernando, Tomo 3, 1923, 267 págs. (Colección Biblioteca Clásica, núm. 160)

Antología de poetas líricos castellanos. Desde la formación del idioma hasta nuestros días, ordenada por Marcelino Menéndez y Pelayo, Madrid, Libreria de Perlado, Páez y Compañia. Sucesores de Hernando, Tomo 6, 1920, 401 págs. (Colección Biblioteca Clásica, núm. 196)

Antología de poetas líricos castellanos. Romances viejos castellanos (Primavera y Flor de Romances), introducción y anotación de Conrado Hoffman y Fernando José Wolf, segunda edición corregida y adicionada por Marcelino Menéndez Pelayo, Madrid, Librería de Hernando y Compañia, Tomo 9, 1912, 360 págs. [Tomo 2] (Colección Biblioteca Clásica, núm. 209)

Antología de poetas líricos castellanos. Desde la formación del idioma hasta nuestros dias, ordenada por Marcelino Menéndez y Pelayo, Madrid, Libreria de Hernando y Compañia, Tomo 7, s.a., 440 págs. (Colección Biblioteca Clásica, núm. 205)

Antología de poetas líricos castellanos. 14. Boscán y Garcilaso de la Vega, con un estudio crítico de José Rogerio Sánchez, Madrid, Librería de los sucesores de Hernando, Tomo 14, 1916, 267 págs. (Colección Biblioteca Clásica, núm. 237)

Antología de poetas líricos castellanos. 11. Tratado de los romances viejos, por Marcelino Menéndez y Pelayo, Madrid, Librería de los sucesores de Hernando, Tomo 11, 1924, 383 págs. [Tomo 1] (Colección Biblioteca Clásica, núm. 213)

Antología de poetas líricos castellanos. 12. Tratado de los romances viejos, por Marcelino Menéndez Pelayo, Madrid, Librería y Casa editorial Hernando, Tomo 12, 1926, 549 págs. [Tomo 2] (Colección Biblioteca Clásica, núm. 214)

Antología de poetas líricos castellanos. 13. Juan Boscán, estudio crítico por Marcelino Menéndez y Pelayo, Madrid, Librería de los sucesores de Hernando, Tomo 13, 1919, 485 págs. (Colección Biblioteca Clásica, núm. 220)

Antología de poetas líricos castellanos. 10. Romances populares recogidos de la tradición oral, con notas y observaciones de 
Marcelino Menéndez y Pelayo, Madrid, Librería de Hernando y Compañía, Tomo 10, 1913, 1913 págs. [Tomo 3. Suplemento a "Primavera y Flor de romances" de Fernando José Wolf] (Colección Biblioteca Clásica, núm. 211)

Antología de poetisas líricas, Madrid, Real Academia Española, Tomo 2, 1915, 369 págs. (Colección Biblioteca selecta de Clásicos Españoles)

Anton del Olmet, Luis y Torres Bernal, José de, Los grandes españoles. Palacio Valdés. Análisis de ese alma blanca y angélica y de ese astro sano y optimista que se llama D. Armando Palacio Valdés, Madrid, Imprenta Juan Pueyo, 1919, 294 págs.

Apollinaire, Guillaume, Les Trois Don Juan. Don Juan Tenorio d'Espagne, don Juan de Maraña des Flandres, don Juan d'Angleterre, París, Bibliothèque des Curieux, 1914, 320 págs. [Ouvrage orné de douze illustrations hors texte. D'après Goya, Boucher, A. Colin, L. Sauvé, J. Harrewyn, de Novelli, E. Devéria, Eugène Delacroix] (Colección L'Histoire Romanesque)

Apuleyo, Lucio, La metamorfosis o el asno de oro, trad. Diego López de Cortegana, Madrid, Librería de Perlado, Páez y Compañía. Sucesores de Hernando, 1914, 335 págs. (Colección Biblioteca Clásica, núm. 143)

Arce Blanco, Margot, Garcilaso de la Vega. Contribución al estudio de la lírica española del siglo XVI, Madrid, Imprenta de la Librería y Casa Editorial Hernando, 1930, 140 págs. [Junta para la Ampliación de Estudios. Centro de Estudios Históricos] (Colección Revista de Filología Española. Anejo, núm. 13)

Arciniegas, Germán, El estudiante de la mesa redonda, Madrid, Pueyo, 1932, 248 págs.

Arnauld, Celine, Anthologie Celine Arnauld. Morecaux Choisis de 1919 a 1935, ¿Bruxelles?, Les cahiers du Journal des Poètes, 1936, 178 págs. [No 3. Février] (Colección Série Anthologique, núm. 3)

Arnauld, Celine, Heures intactes. Poèmes, Bruxelles, Les cahiers du Journal des Poètes, 1936, 52 págs. [№ 1. Janvier] (Colección Série Poétique, núm. 1)

Arnoux, Alexandre, Poésie du Hasard, París, Bernard Grasset, 1934, 246 págs.

Arona, Juan de, Poesías del P. Arolas, edición y prólogo de José Ramón Lomba y Pedraja, Madrid, Ediciones La Lectura, 1928, 290 págs. (Colección Clásicos Castellanos, núm. 95)

Asturias, Miguel Ángel, Rayito de estrella, Paris, Imprimerie Française de l'edition, 1929.

Auclair, Marcel, Toya, París, Librairie Gallimard. Éditions de la Nouvelle Revue Française, 1927, 215 págs.

Audisio, Gabriel, Antée suivi de plusieurs autres poèmes, MarseiIle, Les cahiers du sud, 1932, 90 págs. [Édition ornée d'un portrait de l'auteur par Étienne Bouchaud]
Audisio, Gabriel, Hommes au Soleil, s.l., Le Mouton Blanc, 1923, 104 págs.

Audisio, Gabriel, Ici-Bas. Poème, Alger, Imprimerie Basset, 1927, 44 págs.

Audisio, Gabriel, Poème de la Joie, París, Edition du Solitaire, 1924, 42 págs.

Audisio, Gabriel, Trois hommes et un minaret, París, F. Rieder et Cie, 1926, 186 págs.

Autobiografías y memorias, colección e ilustraciones de Serrano y Sanz, Madrid, Bailly Bailliére, 1905, 545 págs. (Colección Los clásicos olvidados. Nueva Biblioteca de Autores Españoles, núm. 2)

Ayala, Francisco, Indagación del cinema, Madrid, CIAP. Mundo Latino, 1929, 178 págs.

Ayala, Francisco, Tragicomedia de un hombre sin espíritu. Novela, Madrid, Industrial Gráfica, 1925, 278 págs.

Azorín, Blanco en Azul. Cuentos, Madrid, Biblioteca Nueva, 1929, 277 págs. [Precede al título "Nuevas obras"]

Azorin, Clásicos y modernos, Madrid, Renacimiento, 1913, 346 págs.

Azorín, Los Quinteros y otras páginas, Madrid, Rafael Caro Raggio, 1925, 261 págs.

Azorin, Obras completas. 8. El político. Con un epílogo futurista, Madrid, Rafael Caro Raggio, Tomo 8, 1919, 215 págs.

Azorín, Obras completas. 20. Entre España y Francia. Páginas de un francófilo, Madrid, Rafael Caro Raggio, Tomo 20, 1921, 231 págs.

Azorin, Obras completas. 2. La voluntad, Madrid, Rafael Caro Raggio, Tomo 2, 1919, 307 págs.

Azorín, Obras completas. 7. Fantasías y devaneos, Madrid, Rafael Caro Raggio, Tomo 7, 1920, 247 págs.

Azorín, Obras completas. 27. De Granada a Castelar, Madrid, Rafael Caro Raggio, Tomo 27, 1922, 244 págs.

Azorín, Superrealismo. Prenovela, Madrid, Biblioteca Nueva, 1929, 322 págs. (Colección Nuevas obras)

Azorín, Un discurso de la Cierva comentado por Azorín, Madrid, Renacimiento, 1914, 176 págs.

Bacarisse, Mauricio, El esfuerzo, Madrid, Tipografía de José Yagües, 1917, 134 págs.

Bacarisse, Mauricio, Mitos, Madrid, CIAP. Mundo Latino, ¿1930?, 184 págs.

Ballester, José, Otoño en la ciudad. Novela, s.l., Sudeste, 1930, 175 págs.

Balseiro, José A., "Valle-Inclán, la novela y la política", en Hispania, núm. 5-6, s.l., s.n., Vol. 15, noviembre-diciembre de 1932, 437-464 págs.

ARBOR CLXXXVI 744 julio-agosto [2010] 739-776 ISSN: 0210-1963 
Barga, Corpus, París-Madrid. Un viaje en el año 19, Madrid, Tipografía Fortanet, 1920, 59 págs.

Barnés, Domingo, La salud del espíritu del niño, Madrid, Renacimiento, s.a., 230 págs. (Colección La salud de nuestros hijos, núm. 8)

Baroja, Pío, El mayorazgo de labraz, Barcelona, Imprenta de Heinrich y Cia, 1903, 297 págs. (Colección Biblioteca de novelistas del siglo XX)

Baruzi, Jean, Saint Jean de la Croix et le problème de l'expérience mystique, París, Librairie Félix Alcan, 1924, 790 págs.

Bataillon, Marcel, "Mona. Étude Étymologique", Alger, Imprimerie Jules Carbonel, s.a., 14 págs.

Baüer, Ignacio, Goethe. Ensayo bio-bibliográfico. Antología, Ilustraciones de Antequera Azpiri, Gil Roesset, Bráñez de Hoyos y Benet, Madrid, Librería de Fernando Fe, 1932, 193 págs.

Bautista Andrade, Juan, Diana de Gaita. Poemas, prolog. Enrique Díez Canedo, Madrid, Espasa Calpe, 1930, 156 págs.

Benavente, Jacinto, Teatro. 13. Las cigarras hormigas. Más fuerte que el amor, Madrid, Librería de los sucesores de Hernando, Tomo 13, 1931, 377 págs.

Benavente, Jacinto, Teatro, Madrid, Librería de los sucesores de Hernando, Tomo 1, 1917, 308 págs.

Bergamín, José, El acabóse del año y nuevo de 1934, Madrid, Cruz y Raya, 1933, 309 págs.

Bergamín, José, El arte de birlibirloque. Entendimiento del toreo, Madrid, Plutarco, 1930, 96 págs.

Bergamín, José, Enemigo que huye. Polifumo y coloquio espiritual (1925-1926), Madrid, Biblioteca Nueva, 1927, 142 págs.

Bergamín, José, La decadencia del analfabetismo, Madrid, Cruz y Raya, 1933, 94 págs.

Bergamín, José, La estatua de Don Tancredo, Madrid, Cruz y Raya, 1934, 47 págs.

Bergamín, José, "Las raíces poéticas del "Teatro independiente español y revolucionario" del XVII", en Boletín de la Biblioteca Menéndez y Pelayo, Santander, s.n., 1931, 1-38 págs.

Bergamín, José, Tres escenas en ángulo recto (1924), Madrid, Imprenta Zoila Ascasíbar, 1925, 42 págs. [Librería de León Sánchez Cuesta]

Bever, Adolphe van y Léautaud, Paul, Poètes d'Aujourd'hui. 18801900, París, Société du Mercure de France, 1906, 428 págs. [Accompagnes de Notices biographiques et d'un Essai de Bibliographie]

Bilbao, Luis G., Las confesiones de Federico Muga. La era de las iniciaciones, Madrid, Imprenta Clásica Española, 1917, 160 págs.
Blanco García, Francisco, La literatura española en el siglo XIX, Madrid, Sáenz de Jubera Hermanos, ¿1894?, 400 págs. [Parte tercera]

Bonn, M. J., Prosperity. Ascensión y caída de la riqueza americana, ed. J. L. Goicolea, Madrid, Revista de Occidente, 1931, 196 págs.

Borel, Adrien y Robin, Gilbert, Les rêveurs éveillés, Paris, Librairie Gallimard. Éditions de la Nouvelle Revue Française, 1925, 218 págs. (Colección Les documents bleus, núm. 20)

Boussagol, Gabriel, Anthologie de la Littérature Espagnole. Des débuts a nos jours, París, Librairie Delagrave, 1931, 369 págs.

Bretón de los Herreros, Manuel, Obras de don Manuel Bretón de los Herreros. 1. Teatro, Madrid, Imprenta Miguel Ginesta, Tomo 1, 1883, 466 págs.

Bretón de los Herreros, Manuel, Obras de don Manuel Bretón de los Herreros. 2. Teatro, Madrid, Imprenta Miguel Ginesta, Tomo 2, 1883, 524 págs.

Bretón de los Herreros, Manuel, Obras de don Manuel Bretón de los Herreros. 3. Teatro, Madrid, Imprenta Miguel Ginesta, Tomo 3, 1883, 525 págs.

Bretón de los Herreros, Manuel, Obras de don Manuel Bretón de los Herreros. 4. Teatro, Madrid, Imprenta Miguel Ginesta, Tomo 4, 1884, 566 págs.

Bretón de los Herreros, Manuel, Obras de don Manuel Bretón de los Herreros. 5. Poesías, Madrid, Imprenta Miguel Ginesta, Tomo 5, 1884, 539 págs.

Brull, Mariano, Poemas en menguante, París, Imprenta Le Moil \& Pascaly, 1928, 38 págs.

Bruno, Philip L. P., Observaciones sobre el léxico de Juan de Valdés, s.l., s.n., 1934, 205 págs.

Buendía, Rogelio, Guía de Jardines, Huelva, s.n., 1928, 86 págs. (Colección Papel de Aleluyas)

Buendía, Rogelio, La rueda de color, Huelva, Tipografía Viuda de J. Muñoz, 1923

Buendia, Rogelio, Naufragio en 3 cuerdas de guitarra, Sevilla, Imprenta Manuel Carmona, 1928, 28 págs.

Burgos Lecea, Francisco, Xaicxi, delantero. Cuentos, Madrid, Mundo Literario, 1928, 142 págs.

Burke, Thomas, Noches en Londres, trad. Winifred L. Saunt, Madrid, CIAP. Ediciones Ulises, 1930, 264 págs.

Cadalso, José, Cartas marruecas, prólogo, edición y notas de Juan Tamayo y Rubio, Madrid, Espasa Calpe, 1935, 302 págs. (Colección Clásicos Castellanos, núm. 112)

Cadalso, José, Noches lúgubres. Una de las más bellas obras del poeta y costumbrista, escrita al borde del sepulcro, con todas las fantasías que inspira el terror, notas y prólogo del autor, 
Madrid, Imprenta Juan Pueyo, ¿1918?, 63 págs. (Colección Biblioteca de autores célebres)

Calderón de la Barca, selección de Samuel Gili y Gaya, dibujos de F. Marco, Madrid, Instituto Escuela. Junta para Ampliación de Estudios, 1923, 325 págs. (Colección Biblioteca literaria del estudiante, núm. 11)

Calderón de la Barca, Pedro, Autos Sacramentales, edición, prólogo y notas de Ángel Valbuena Prat, Madrid, Ediciones La Lectura, Vol. 1, 1926, 261 págs. (Colección Clásicos Castellanos, núm. 69)

Calderón de la Barca, Pedro, Autos Sacramentales, edición, prólogo y notas de Ángel Valbuena Prat, Madrid, Ediciones La Lectura, Vol. 2, 1927, 248 págs. (Colección Clásicos Castellanos, núm. 74)

Calderón de la Barca, Pedro, Comedias, colección e ilustraciones de Juan Eugenio Hartzenbusch, Madrid, M. Rivadeneyra, Tomo 1, 1851, 610 págs. (Colección Biblioteca de Autores Españoles, núm. 7)

Calderón de la Barca, Pedro, Comedias, colección e ilustraciones de Juan Eugenio Hartzenbusch, Madrid, M. Rivadeneyra, Tomo 2, 1862, 686 págs. (Colección Biblioteca de Autores Españoles, núm. 9)

Calderón de la Barca, Pedro, Comedias, colección e ilustraciones de Juan Eugenio Hartzenbusch, Madrid, M. Rivadeneyra, Tomo 3, 1863, 736 págs. (Colección Biblioteca de Autores Españoles, núm. 12)

Calderón de la Barca, Pedro, Comedias, colección e ilustraciones de Juan Eugenio Hartzenbusch, Madrid, M. Rivadeneyra, Tomo 4, 1858, 734 págs. (Colección Biblioteca de Autores Españoles, núm. 14)

Calderón de la Barca, Pedro, Teatro selecto de Calderón de la Barca. 1. Dramas religiosos y filosóficos. La vida es sueño. La devoción de la Cruz. El mágico prodigioso. El príncipe constante, precedido de un estudio crítico de Marcelino Menéndez y Pelayo, Madrid, Librería de Perlado, Páez y Compañía. Sucesores de Hernando, Tomo 1, 1918, 430 págs. (Colección Biblioteca Clásica, núm. 36)

Calderón de la Barca, Pedro, Teatro selecto de Calderón de la Barca. 2. Dramas trágicos. El médico de su honra. A secreto agravio secreta venganza. El Alcalde de Zalamea. El mayor monstruo los celos. Amar después de la muerte, Precedido de un estudio de Marcelino Menéndez y Pelayo, Madrid, Librería de Perlado, Páez y Compañía. Sucesores de Hernando, Tomo 2, s.a., 569 págs. (Colección Biblioteca Clásica, núm. 37)

Calderón de la Barca, Pedro, Teatro selecto de Calderón de la Barca. 3. Comedias de capa y espada. Casa con dos puertas mala es de guardar. La dama duende. No hay burlas con el amor. Mañanas de abril y mayo, precedido de un estudio de Marcelino Menéndez y Pelayo, Madrid, Librería de Perlado, Páez y Compañía. Sucesores de Hernando, Tomo 3, 1917, 445 págs. (Colección Biblioteca Clásica, núm. 38)

Camoëns, Luis de, Los Lusíadas, trad. Lamberto Gil, Madrid, Librería de Perlado, Páez y Compañía. Sucesores de Hernando, 1921, 459 págs. (Colección Biblioteca Clásica, núm. 100)

Camoëns, Luis de, Poesías selectas, trad. Lamberto Gil, Madrid, Librería de los sucesores de Hernando, 1914, 350 págs. (Colección Biblioteca Clásica, núm. 101)

Campoamor, Ramón de, El drama universal, poema en ocho jornadas, Madrid, Imprenta de M. Rivadeneyra, 1869, 400 págs.

Campoamor, Ramón de, Poesías, ed. Cipriano Rivas Cherif, Madrid, Ediciones La Lectura. Espasa Calpe, 1932, 308 págs. (Colección Clásicos Castellanos, núm. 40)

Canalejas, Francisco de Paula, La poesía moderna. Discursos críticos, Madrid, Imprenta de la revista de la legislación, 1877, 214 págs.

Cancionero castellano del siglo XV, ordenado por R. Foulché Delbosc, Madrid, Bailly Bailliére, Tomo 1, 1912, 771 págs. (Colección Los clásicos olvidados. Nueva Biblioteca de Autores Españoles, núm. 19)

Cancionero Castellano del siglo XV, ordenado por R. Foulché Delbosc, Madrid, Bailly Bailliére, Tomo 2, 1915, 789 págs. (Colección Los clásicos olvidados. Nueva Biblioteca de Autores Españoles, núm. 22)

Cansinos-Assens, Rafael, La nueva literatura. 2. Las escuelas (1898, 1900-1918), Madrid, Editorial Páez, Vol. 2, 1925, 378 págs.

Cantos populares españoles, recogidos, ordenados e ilustrados por Francisco Rodríguez Marín, Sevilla, Francisco Álvarez y Compañía, Tomo 5, 1883, 238 págs.

Carande, Ramón, Sevilla, Fortaleza y mercado. Algunas instituciones de la ciudad, en el siglo XIV especialmente, estudiadas en sus privilegios, ordenamientos y cuentas, Madrid, Tipografía de la Revista de Archivos, 1925, 169 págs. [Del Anuario de Historia del Derecho español, Tomo 2]

Carmen. Al maestro Fray Luis de León, núms. 3-4, s.l., s.n., marzo de 1928 [Sin paginar. Dentro los números 3-4 de Lola]

Carmen. Revista chica de poesía española, núm. 1, s.l., s.n., diciembre de 1927 [Sin paginar. Dentro el suplemento Lola número 1.]

Carmen. Revista chica de poesía española, núm. 2, s.l., s.n., enero de 1928 [Sin paginar. Dentro suplemento Lola núm. 2]

Carmen. Revista chica de poesía española, núm. 5, s.l., s.n., abril de 1928 [Sin paginar. Dentro suplementos 5 y 6-7 de Lola]

ARBOR CLXXXVI 744 julio-agosto [2010] 739-776 ISSN: 0210-1963

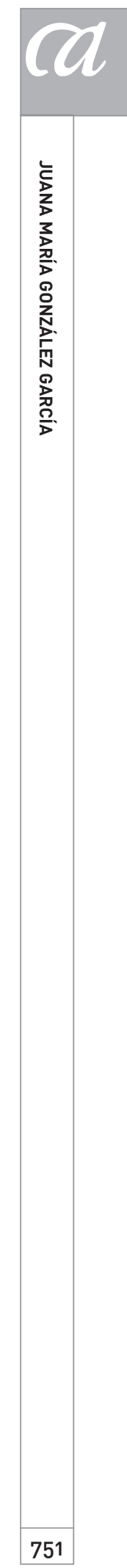

doi: 10.3989/arbor.2010.744n1230 
Carmen. Revista chica de poesía española, núm. 6-7, s.l., s.n., junio de 1928 [Sin paginar].

Casais Monteiro, Adolfo, Confusao, Coimbra, Presença, 1929, 70 págs.

Casares, Julio, Crítica profana. Valle-Inclán, Azorín, Ricardo León, Madrid, Imprenta Colonial, 1916, 365 págs.

Cascales Muñoz, José, D. José de Espronceda. Su época, su vida y sus obras, Madrid, Biblioteca Hispania, 1914, 350 págs.

Cascales, Francisco, Cartas Filológicas, edición, introducción y notas de Justo García Soriano, Madrid, Ediciones La Lectura, Vol. 1, 1930, 268 págs. (Colección Clásicos Castellanos, núm. 103)

Cassou, Jean, Éloge de la Folie. Roman, París, Éditions Émile-Paul Fréres, 1925, 307 págs. (Colección Edmond Jaloux)

Cassou, Jean, La Clef des Songes. Roman, París, Éditions ÉmilePaul Fréres, 1929, 253 págs.

Cassou, Jean, Le Gréco, París, Les Éditions Rieder, 1931, 60 págs. (Colección Maitres de l'art ancien)

Cassou, Jean, Le Pays qui n'est a personne. Roman, Paris, Éditions Émile-Paul Fréres, 1928, 211 págs. (Colección Edmond Jaloux)

Cassou, Jean, Les Harmonies Viennoises, Paris, Éditions Émile-Paul Fréres, 1926, 211 págs. (Colección Edmond Jaloux)

Castañeda, Daniel, Las Islas del Sueño. Poemas, seguidos de la primera versión en castellano de "Poemas condenados" de Charles Baudelaire, México, Cultura, 1927, 192 págs.

Castillejo, Cristóbal de, Obras. 1. Sermón de amores. Diálogo de mujeres, edición, prólogo y notas de J. Domínguez Bordona, Madrid, Ediciones La Lectura, Vol. 1, 1926, 310 págs. (Colección Clásicos Castellanos, núm. 72)

Castillejo, Cristóbal de, Obras. 3. Obras de conversación y pasatiempo (Conclusión). Obras morales y de devoción, ed. J. Domínguez Bordona, Madrid, Ediciones La Lectura, Vol. 3, 1928, 258 págs. (Colección Clásicos Castellanos, núm. 88)

Castillejo, Cristóbal de, Obras. 4. Obras morales y de devoción (Conclusión). Fragmentos de La Constanza. Carta Dedicatoria, edición y notas de J. Domínguez Bordona, Madrid, Ediciones La Lectura, Vol. 4, 1928, 243 págs. (Colección Clásicos Castellanos, núm. 91)

Castillo Elejabeytia, Dictinio, Nebulosas, llustraciones de M. López Gil, Madrid, Libreria de San Martín, 1935, 200 págs.

Castro y Bravo, Federico de, Las Naos Españolas en la carrera de las Indias. 2. Serie A. Armadas y flotas en la segunda mitad del siglo XVI, Madrid, Voluntad, Vol. 2, 1927, 284 págs. (Colección Hispania)
Castro, Américo, "Erasmo en tiempo de Cervantes", en Revista de Filología Española, Madrid, Imprenta de la Librería y Casa Editorial Hernando, Tomo 18, 1931, 329-389 págs.

Castro, Américo, Santa Teresa y otros ensayos. Algo de Edad Media, El poema de Flamenca, El príncipe D. Juan, Recordando a Erasmo, El problema histórico de La Celestina, Cervantes y Pirandello, etc., Santander, Historia Nueva, 1929, 278 págs.

Castro, Eugenio de, Camafeus Romanos, Coimbra, Lumen, 1921, 92 págs.

Castro, Eugenio de, Interlunio, Coimbra, F. França Amado, 1911, 83 págs.

Castro, Eugenio de, Silva, Porto, Magalhaes \& Moniz, 1911, 114 págs.

Castro, Guillén de, Las mocedades del Cid, anotación de Víctor Said Armesto, Madrid, Ediciones de La Lectura, 1923, 286 págs. (Colección Clásicos Castellanos, núm. 15)

Catalá Lloret, Rafael, Inquietud, prólogo de Wencesalo Fernández Flórez, s.l., Sociedad Castellonense de Cultura, 1931, 196 págs.

Cejador y Frauca, Julio, Historia de la lengua castellana. Época de Carlos V, Madrid, Tipografía de la Revista de Archivos, Bibliotecas y Museos, 1915, 292 págs.

Cejador y Frauca, Julio, Historia de la lengua y literatura casteIlana comprendidos los autores hispano-americanos. Época del siglo Siglo XVIII. 1701-1820, Madrid, Tipografía de la Revista de Archivos, Bibliotecas y Museos, Tomo 6, 1917, 466 págs.

Cendrars, Blaise, Anthologie nègre, Paris, Au Sans Pareil, 1927, 320 págs.

Cendrars, Blaise, Du monde entier, París, Nouvelle Revue Française, 1919, 129 págs.

Cernuda, Luis, Donde habite el olvido, Madrid, Signo, 1934, 38 págs.

Cernuda, Luis, La realidad y el deseo, Madrid, Cruz y Raya, 1936, 212 págs.

Cernuda, Luis, Perfil del aire, Málaga, Imprenta Sur, 1927, 52 págs. [4 ${ }^{\circ}$ suplemento de Litoral]

Cervantes y de los Ríos, Pedro de, El libro de los cien sonetos, prólogo de Federico Gamboa, ilustraciones de F. Marco, Madrid, Talleres Espasa Calpe, 1926, 213 págs.

Cervantes, Miguel de, El ingenioso hidalgo don Quijote de la Mancha, comentado por Diego Clemencín, Madrid, Librería de la viuda de Hernando y Compañía, Tomo 1, 1894, 336 págs. (Colección Biblioteca Clásica, núm. 180)

Cervantes, Miguel de, El ingenioso hidalgo don Quijote de la Mancha, comentado por Diego Clemencín, Madrid, Librería de la 
viuda de Hernando y Compañía, Tomo 2, 1894, 378 págs. (Colección Biblioteca Clásica, núm. 181)

Cervantes, Miguel de, El ingenioso hidalgo don Quijote de la Mancha, comentado por Diego Clemencín, Madrid, Librería de Perlado, Páez y Compañía. Sucesores de Hernando, Tomo 3, 1917, 394 págs. (Colección Biblioteca Clásica, núm. 182)

Cervantes, Miguel de, El ingenioso hidalgo don Quijote de la Mancha, comentado por Diego Clemencín, Madrid, Librería de los sucesores de Hernando, Tomo 4, 1917, 366 págs. (Colección Biblioteca Clásica, núm. 183)

Cervantes, Miguel de, El ingenioso hidalgo don Quijote de la Mancha, comentado por Diego Clemencín, Madrid, Librería de Perlado, Páez y Compañía. Sucesores de Hernando, Tomo 5, 1917, 376 págs. (Colección Biblioteca Clásica, núm. 184)

Cervantes, Miguel de, El ingenioso hidalgo don Quijote de la Mancha, comentado por Diego Clemencín, Madrid, Librería de Perlado, Páez y Compañía. Sucesores de Hernando, Tomo 6, 1917, 393 págs. (Colección Biblioteca Clásica, núm. 185)

Cervantes, Miguel de, El ingenioso hidalgo don Quijote de la Mancha, comentado por Diego Clemencín, Madrid, Librería de Perlado, Páez y Compañía. Sucesores de Hernando, Tomo 7, 1917, 394 págs. (Colección Biblioteca Clásica, núm. 186)

Cervantes, Miguel de, El ingenioso hidalgo don Quijote de la Mancha, comentado por Diego Clemencín, Madrid, Librería de Perlado, Páez y Compañía. Sucesores de Hernando, Tomo 8, 1917, 390 págs. (Colección Biblioteca Clásica, núm. 187)

Cervantes, Miguel de, El ingenioso Hidalgo don Quijote de la Mancha. Novela, Madrid, Calpe, Tomo 2, 1920, 382 págs. (Colección Universal, núm. 352-355)

Cervantes, Miguel de, El ingenioso Hidalgo don Quijote de la Mancha. Novela, Madrid, Calpe, Tomo 4, 1921, 395 págs. (Colección Universal, núm. 387-390)

Cervantes, Miguel de, Novelas ejemplares, edición y anotación de Francisco Rodríguez Marín, Madrid, Ediciones La Lectura, Vol. 1, 1914, 343 págs. (Colección Clásicos Castellanos)

Cervantes, Miguel de, Vida de D. Quijote y Sancho según Miguel de Cervantes Saavedra, explicada y comentada por Miguel de Unamuno, Madrid, Librería de Fernando Fe, 1905, 427 págs.

César, Cayo Julio, Los comentarios de Cayo Julio César, trad. José Goya y Muniain, Madrid, Librería de Perlado, Páez y Compañia. Sucesores de Hernando, Tomo 1, 1920, 273 págs. [Nueva edición que comprende los libros escritos por Hircio y traducidos por Manuel Balbuena] (Colección Biblioteca Clásica, núm. 44)

César, Cayo Julio, Los comentarios de Cayo Julio César, trad. José Goya y Muniain, Madrid, Librería de Perlado, Páez y Com- pañía. Sucesores de Hernando, Tomo 2, 1923, 331 págs. [Nueva edición que comprende los libros escritos por Hircio y traducidos por Manuel Balbuena] (Colección Biblioteca Clásica, núm. 45)

Céspedes y Meneses, Gonzalo de, Historias peregrinas y ejemplares, con noticias del autor y de la obra por Emilio Cotarelo y Mori, Madrid, Librería de la viuda de Rico, Tomo 2, 1906, 425 págs. (Colección Selecta de Antiguas Novelas Españolas)

Chabás, Juan, Agor sin fin. Novela, Madrid/Buenos Aires, Ediciones Ulises, 1930, 340 págs. (Colección Valores actuales)

Chabás, Juan, Puerto de Coimbra. Novela, Madrid, Rafael Caro Raggio, s.a., 138 págs.

Chabás, Juan, Vuelo y Estilo. Estudios de Literatura contemporánea. 1. G. Miró, J. Ramón Jiménez, Antonio Machado, Manuel Machado, Madrid, Sociedad General Española de Libreria, Tomo 1, 1934, 160 págs.

Chacón y Calvo, José María, El documento y la reconstrucción histórica, La Habana, Revista de Avance, 1929, 87 págs.

Chacón y Calvo, José María, Ensayos de literatura española, Madrid, Libreria y Casa editorial Hernando, 1928, 203 págs.

Chacón y Calvo, José María, Literatura Cubana. Ensayos Críticos, Madrid, Biblioteca Calleja, 1922, 277 págs.

Champourcín, Ernestina de, La voz en el viento (1928-1931), Madrid, CIAP, ¿1932?, 138 págs.

Char, René, Le Marteau sans Maitre, Paris, Éditions Surréalistes, 1934, 142 págs.

Chaytor, H. J., La vida de Lazarillo de Tormes, London, Manchester University Press. Longmans, Green \& Co., 1922, 65 págs. [Editor general de la colección, E. Allison Peers] (Colección Modern Language Texts. Spanish Series)

Choisy, Maryse, Un mois chez les filles. Reportage, París, Éditions Montaigne, 1928, 254 págs. (Colección Du Gai Savoir, núm. 9)

Church, Henry, Barnum. Comédie en deux actes, París, Hors Commerce, 1929, 105 págs.

Cicerón, Marco Tulio, Obras completas de Marco Tulio Cicerón, trad. Marcelino Menéndez y Pelayo, Madrid, Librería de los sucesores de Hernando, Tomo 1, 1924, 273 págs. (Colección Biblioteca Clásica, núm. 14)

Cicerón, Marco Tulio, Obras completas de Marco Tulio Cicerón, trad. Marcelino Menéndez y Pelayo, Madrid, Librería de Perlado, Páez y Compañía. Sucesores de Hernando, Tomo 2, 1914, 388 págs. (Colección Biblioteca Clásica, núm. 26)

Cicerón, Marco Tulio, Obras completas de Marco Tulio Cicerón, trad. Marcelino Menéndez y Pelayo, Madrid, Librería de Perlado, Páez y Compañía. Sucesores de Hernando, Tomo 3, 1914, 359 págs. (Colección Biblioteca Clásica, núm. 59)

ARBOR CLXXXVI 744 julio-agosto [2010] 739-776 ISSN: 0210-1963

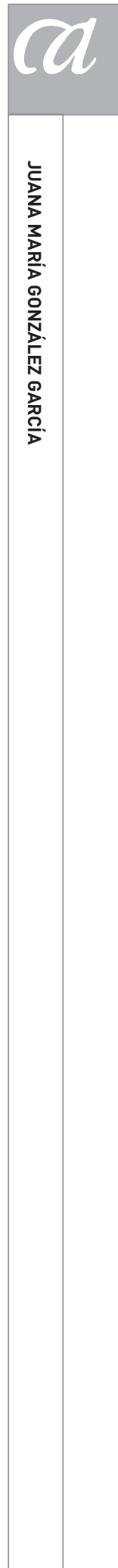


Cicerón, Marco Tulio, Obras completas de Marco Tulio Cicerón, trad. Manuel de Valbuena, Madrid, Librería de los sucesores de Rivadeneyra, Tomo 4, 1914, 341 págs. (Colección Biblioteca Clásica, núm. 60)

Cicerón, Marco Tulio, Obras completas de Marco Tulio Cicerón, trad. Marcelino Menéndez y Pelayo, Madrid, Librería de Perlado, Páez y Compañia. Sucesores de Hernando, Tomo 5, 1912, 247 págs. (Colección Biblioteca Clásica, núm. 73)

Cicerón, Marco Tulio, Obras completas de Marco Tulio Cicerón, trad. Francisco Navarro y Calvo, Madrid, Librería de los sucesores de Hernando, Tomo 6, 1924, 351 págs. (Colección Biblioteca Clásica, núm. 75)

Cicerón, Marco Tulio, Obras completas de Marco Tulio Cicerón. 7. Epistolas familiares I, trad. Pedro Simón Abril, Madrid, Librería de los sucesores de Hernando, Tomo 7, 1924, 360 págs. (Colección Biblioteca Clásica, núm. 77)

Cicerón, Marco Tulio, Obras Completas de Marco Tulio Cicerón. 8. Epistolas familiares II, trad. Pedro Simón Abril, Madrid, Librería de los sucesores de Hernando, Tomo 8, 1924, 403 págs. (Colección Biblioteca Clásica, núm. 79)

Cicerón, Marco Tulio, Obras completas de Marco Tulio Cicerón. 1. Cartas políticas, trad. Francisco Navarro y Calvo, Madrid, Librería y Casa editorial Hernando, Tomo 9, 1927, 408 págs. (Colección Biblioteca Clásica, núm. 83)

Cicerón, Marco Tulio, Obras completas de Marco Tulio Cicerón. 10. Cartas políticas II, trad. Francisco Navarro y Calvo, Madrid, Librería y Casa editorial Hernando, Tomo 10, 1927, 459 págs. (Colección Biblioteca Clásica, núm. 86)

Cicerón, Marco Tulio, Obras completas de Marco Tulio Cicerón. 11. I. Vida y discursos, trad. Díaz Tendero y Fernández Llera y Calvo, Madrid, Librería de Perlado, Páez y Compañía. Sucesores de Hernando, Tomo 11, 1917, 344 págs. (Colección Biblioteca Clásica, núm. 202)

Cicerón, Marco Tulio, Obras completas de Marco Tulio Cicerón. 12. II. Vida y discursos, trad. Díaz Tendero y Fernández Llera y Calvo, Madrid, Librería de Perlado, Páez y Compañía. Sucesores de Hernando, Tomo 12, 1917, 358 págs. (Colección Biblioteca Clásica, núm. 203)

Cicerón, Marco Tulio, Obras completas de Marco Tulio Cicerón. 13. III. Vida y discursos, trad. Díaz Tendero y Fernández Llera Calvo, Madrid, Librería de Perlado, Páez y Compañía. Sucesores de Hernando, Tomo 13, 1917, 382 págs. (Colección Biblioteca Clásica, núm. 204)

Cicerón, Marco Tulio, Obras completas de Marco Tulio Cicerón. 14. IV. Vida y discursos, trad. Díaz Tendero y Fernández Llera Calvo, Madrid, Librería de los sucesores de Hernando, Tomo 14, 1917, 410 págs. (Colección Biblioteca Clásica, núm. 206)
Cicerón, Marco Tulio, Obras completas de Marco Tulio Cicerón. 15. V. Vida y discursos, trad. Díaz Tendero y Fernández Llera Calvo, Madrid, Librería de Perlado, Páez y Compañía. Sucesores de Hernando, Tomo 15, 1919, 376 págs. (Colección Biblioteca Clásica, núm. 207)

Cicerón, Marco Tulio, Obras completas de Marco Tulio Cicerón. 16. VI Vida y discursos, trad. Díaz Tendero y Fernández Llera Calvo, Madrid, Librería de Perlado, Páez y Compañía. Sucesores de Hernando, Tomo 16, 1919, 393 págs. (Colección Biblioteca Clásica, núm. 210)

Cicerón, Marco Tulio, Obras completas de Marco Tulio Cicerón. 17. VII. Vida y discursos, trad. Díaz Tendero y Fernández Llera Calvo, Madrid, Libreria de Hernando y Compañía, Tomo 17, 1922, 548 págs. (Colección Biblioteca Clásica, núm. 212)

Claudel, Paul, Cinq Grandes Odes. Suivies d'un processionnal pour saluer le siècle nouveau, París, Nouvelle Revue Française, 1913, 204 págs. [Nouvelle édition augmentée d'arguments]

Claudel, Paul, Deux farces lyriques. Protée. L'ours et la lune, París, Librairie Gallimard. Éditions de la Nouvelle Revue Française, 1927, 222 págs.

Cocteau, Jean, Le Grand Écart. Roman, París, Librairie Stock, 1923, 203 págs.

Cocteau, Jean, Poésie. 1916-1923, París, Librairie Gallimard. Éditions de la Nouvelle Revue Française, 1925, 468 págs.

Coeuroy, A. y Clarence, G., Le phonographe, Paris, Éditions Kra, 1929, 194 págs.

Colección de cantos populares, anotación de Ignacio del Alcázar, Madrid, Antonio Aleu. Imprenta de Ambrosio Pérez, Tomo 1, 1910, 381 págs.

Colette Willy, La Paix chez les bêtes. Frontispice de Steinlen, París, Éditions Georges Crès et Cie, 1916, 242 págs.

Coloma, Luis, Pequeñeces..., Bilbao, Administración de "El mensajero del corazón de Jesús", 1891, 452 págs. [Libro tercero]

Comandante X. Y., La espada rota. Impresiones de campaña, Burgos, Imprenta de Rafael Y. de Aldecoa, 1922, 279 págs. [Palabras finales por Francisco de Cossío. Marrue$\cos 1922]$

Comedias escogidas de Fray Gabriel Tellez (el maestro de Tirso de Molina), colección e ilustraciones de Juan Eugenio Hartzenbusch, Madrid, M. Rivadeneyra, 1885, 724 págs. (Colección Biblioteca de Autores Españoles, núm. 5)

Conde, Carmen, Júbilos. Poemas de niños, rosas, animales, máquinas y vientos, prólogo de Gabriela Mistral, Murcia, Sudeste, 1934, 137 págs. [Dibujos de Norah Borges de Torre] (Colección Varietas, núm. 3)

Constant, Benjamin, Adolfo, trad. Antonio Espina, Madrid, Calpe, 1924, 122 págs. (Colección Universal, núm. 945) 
Corominas, Pedro, El sentimiento de la riqueza en Castilla. Conferencias dadas en la Residencia de Estudiantes los días 24, 26 y 28 de marzo de 1917, Madrid, Publicaciones de la Residencia de Estudiantes, 1917, 251 págs. [Serie II. Vol. 12]

Cortina, Augusto, Desfile de imágenes, Madrid, Sucesores de Rivadeneyra, 1929, 137 págs.

Cortina, Augusto, "Rodrigo Cota". Tirada a parte de de la Revista de la Biblioteca, Archivo y Museo del Ayuntamiento de Madrid, Madrid, Imprenta Municipal, 1929, 17 págs.

Cossío, Manuel B., La enseñanza primaria en España, ed. Luzuriaga, Lorenzo, Madrid, R. Rojas, 1915, 214 págs. (Colección Museo Pedagógico Nacional)

Cota, Rodrigo, Diálogo entre el amor y un viejo, Buenos Aires, Imprenta y Casa editora "Coni", 1929, 78 págs. [Trabajos de los alumnos en los cursos de seminario y de lectura y comentario de textos II Letras. Edición crítica dirigida por Augusto Cortina anotada por los alumnos de la Facultad de Humanidades de la Universidad de la Plata]

Courthion, Pierre, Panorama de la Peinture Française Contemporaine, Paris, Éditions Kra, 1927, 191 págs.

Crónicas del Gran Capitán, por Antonio Rodríguez Villa, Madrid, Bailly Bailliére, 1908, 612 págs. (Colección Los clásicos olvidados. Nueva Biblioteca de Autores Españoles, núm. 10)

Cruz, Ramón de la, Sainetes de Ramón de la Cruz, colección de Emilio Cotarelo y Mori, Madrid, Bailly Bailliére, Tomo 1, 1915, 550 págs. (Colección Los clásicos olvidados. Nueva Biblioteca de Autores Españoles, núm. 23)

Cruz, Ramón de la, Sainetes, colección de Emilio Cotarelo y Mori, Madrid, Bailly Bailliére, Tomo 2, 1928, 467 págs. (Colección Los clásicos olvidados. Nueva Biblioteca de Autores Españoles, núm. 26)

Cubillo de Aragón, Álvaro, Las muñecas de Marcela. El Señor de Noches Buenas, edición y estudio por Ángel Valbuena Prat, Madrid, CIAP, 1928 MCMXXVIII, 235 págs. [Colección dirigida por Pedro Sáinz Rodríguez] (Colección Nueva Biblioteca de Autores Españoles. Los Clásicos olvidados, núm. 3)

Cuentos de los siglos XVI y XVII, ed. M. Herrero Garcia, Madrid, Instituto Escuela. Junta para Ampliación de Estudios, 1926, 285 págs. (Colección Biblioteca literaria del estudiante, núm. 23)

Cueva, Juan de la, El infamador, Los siete infantes de Lara y El Ejemplar poético, edición, introducción y notas de Francisco A. de Icaza, Madrid, Ediciones La Lectura, 1924, 246 págs. (Colección Clásicos Castellanos, núm. 60)

Cuevas, Raúl, Noches y días. Poemas, Santiago de Chile, Imprenta Nascimiento, 1929, 60 págs.

Curiosidades bibliográficas. Colección escogida de obras raras de amenidad y erudición con apuntes biográficos de los diferentes autores, apuntes biográficos de los diferentes autores por Adolfo de Castro, Madrid, M. Rivadeneyra, Tomo 36, 1855, 556 págs. (Colección Biblioteca de Autores Españoles, núm. 36)

D'Annunzio, Gabriel, Sueño de un atardecer de otoño. Poema trágico, trad. Ricardo Baeza, Madrid, Imprenta Helénica, 1911, 76 págs.

D'Ors, Eugenio, Aprendizaje y heroísmo. Lectura dada en la Residencia de Estudiantes la noche del 20 de enero de 1915 Madrid, Publicaciones de la Residencia de Estudiantes, 1915, 68 págs. [Serie IV. Vol. 5]

D'Ors, Eugenio, Cezanne, Madrid, Rafael Caro Raggio, ¿1925?, 141 págs.

D'Ors, Eugenio, Cinco minutos de silencio, Valencia, Sempere, 1925, 231 págs.

D'Ors, Eugenio, Europa, Madrid, Rafael Caro Raggio, 1922, 219 págs. [1920. Octubre, noviembre, diciembre] (Colección El nuevo glosario, núm. 4)

D'Ors, Eugenio, Grandeza y servidumbre de la inteligencia, Madrid, Publicaciones de la Residencia de Estudiantes, ¿1919?, 71 págs. [Serie IV. Vol. 8.]

D'Ors, Eugenio, Guillermo Tell. Tragedia política en tres jornadas, Valencia, Editorial Sempere, 1926, 259 págs. [1923. Abril, mayo, junio]

D'Ors, Eugenio, Hambre y sed de verdad, Madrid, Rafael Caro Raggio, 1922, 227 págs. [Julio, Agosto, Septiembre] (Colección El nuevo glosario, núm. 3)

D'Ors, Eugenio, La vie de Goya, trad. Marcel Carayon, París, Librairie Gallimard. Éditions de la Nouvelle Revue Française, 1928, 338 págs. (Colección Vies des hommes illustres, núm. 22)

D'Ors, Eugenio, Mi salón de otoño, Madrid, Revista de Occidente, 1924, 97 págs. [Suplemento núm. 1 de la Revista de Occidente. Abril. Primera serie.]

D'Ors, Eugenio, Poussin y el Greco, Madrid, Rafael Caro Raggio, 1922, 213 págs. [Año II, 1921. Vol. 1. Enero, febrero, marzo.] (Colección El nuevo glosario, núm. 5)

Darío, Rubén, Canto a la Argentina y otros Poemas, Madrid, Biblioteca Corona, Tomo 30, 1914, 157 págs.

Darío, Rubén, Cantos de vida y esperanza. Los cisnes y otros poemas, Barcelona/Madrid, F. Granada y Cía, 1907, 175 págs.

Darío, Rubén, Muy siglo XVIII, Madrid, Biblioteca Corona, 1914, 159 págs.

Dauzat, Albert, L'Espagne. Telle qu'elle est, París, Société d'Édition et de Publications. Librairie Félix Juven, 1911, 334 págs.

De la Torre, Claudio, En la vida del señor alegre. Novela, Madrid, Rafael Caro Raggio, 1924, 316 págs.

ARBOR CLXXXVI 744 julio-agosto [2010] 739-776 ISSN: 0210-1963

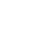


De Lapi, Fernando, Suma Poética 1908-1924, Madrid, Mundo Latino, 1925, 233 págs.

Deffoux, Leon, Le naturalisme, París, Les oeuvres représentatives, 1929, 284 págs. [Colección dirigida por René Lalou] (Colección Le XIXe Siècle)

Délano, Luis Enrique, Viaje de sueño, Santiago de Chile, Ediciones Ercilla, 1935, 113 págs.

Delgado, Félix, Paisajes y otras visiones. Poemas, prólogo de Claudio de la Torre, Gran Canaria, Biblioteca de "La Isla", 1923, 116 págs.

Delpy, Gaspard y Viñas, Aurelio, L'Espagnol par les textes, s.l., Hachette, 1927, 301 págs.

Delteil, Joseph, Don Juan, París, Bernard Grasset, 1930, 265 págs.

Delteil, Joseph, Mes Amours... spirituelles, Paris, Albert Messein, 1926, 197 págs. [Colección dirigida por Jean Royere] (Colección La Phalange)

Deschamps, Émile, La préface des études françaises et étrangères. Un manifieste du romantisme, Paris, Les Presses Françaises, 1923, 87 págs. (Colección Bibliothèque Romantique)

Dickens, Charles, David Copperfield. Novela, trad. Carmen Abréu de Peña, Madrid, Calpe, Tomo 3, 1924, 357 págs. (Colección Universal, núm. 931-934)

Dickens, Charles, La vida y aventuras de Nicolás Nickleby, trad. José Méndez Herrera, Madrid, Espasa Calpe, Tomo 1, 1930, 353 págs. (Colección Universal, núm. 1156-1159)

Dickens, Charles, Martín Chuzzlewit, trad. José Méndez Herrera, Madrid, Espasa Calpe, Tomo 2, 1933, 269 págs. (Colección Universal, núm. 1277-1279)

Dickens, Charles, Martín Chuzzlewit, trad. José Méndez Herrera, Madrid, Espasa Calpe, Tomo 3, 1933, 248 págs. (Colección Universal, núm. 1280-1282)

Diego, Gerardo, El Romancero de la Novia, Madrid, Imprenta de J. Pérez, 1920, 57 págs.

Diego, Gerardo, "Fábula de Equis y Zeda", s.l., Encuadernación de Luis Álvarez Piñer, 1930, 97-112 págs.

Diego, Gerardo, Imagen. Poemas. 1918-1921, Madrid, Gráficas Ambos Mundos, 1922, 119 págs.

Diego, Gerardo, Soria. Galería de estampas y efusiones, Valladolid, Imprenta y Librería de la viuda de Montero, 1923, 72 págs.

Dieste, Rafael, Quebranto de Doña Luparia y otras farsas, Madrid, Juan Pueyo, 1934, 194 págs.

Díez Canedo, Enrique, Algunos versos, Madrid, Cuadernos Literarios, 1924, 143 págs. [Con un retrato del autor por José Moreno Villa]

Díez Canedo, Enrique, Epigramas Americanos, Madrid, Talleres Espasa Calpe, 1928, 42 págs.
Díez Canedo, Enrique, La Visita del Sol, Madrid, Imprenta Gutenberg-Castro, 1907, 148 págs.

Díez Canedo, Enrique, Versos de las Horas, Madrid, Imprenta Ibérica, 1906, 116 págs.

Díez de Medina, Fernando, El Velero Matinal. Ensayos, Bolivia, América, 1935, 284 págs.

Domenchina, Juan José, La corporeidad de lo abstracto, Madrid, Renacimiento, 1929, 219 págs.

Domínguez Bordona, Jesús, Retratos en manuscritos españoles. Conferencias dadas en el Centro de Intercambio Intelectual Germano-Español, Madrid, s.n., 1928, 16 págs. [14 de marzo de 1928, núm. 16]

Don Luis de Góngora y Argote, traducción, introducción y notas de Lucien-Paul Thomas, París, La Renaissance du livre, s.a., 167 págs. (Colección Les Cents chefs-d'ouvre étrangers)

Dos Passos, John, Manhattan-Transfer, trad. Maurice E. Coindreau, París, Librairie Gallimard. Éditions de la Nouvelle Revue Française, 1928, 270 págs.

Dragomirescou, Michel, La Science de la Littérature, París, Librairie Universitaires J. Gamber, Vol. 1, 1928, 218 págs. [Collection publiée sous la direction de L'Institut de Littérature de Bucarest. Éditon refondue, corrigée et augmentée d'après la première édition roumaine] (Colección Bibliothèque de Littérature Universelle)

Dramáticos contemporáneos a Lope de Vega, colección escogida y ordenada con un discurso, apuntes biográficos y críticos de los autores, noticias bibliográficas y catálogos por Ramón Mesonero Romanos, Madrid, M. Rivadeneyra, Tomo 1, 1857, 581 págs. (Colección Biblioteca de Autores Españoles, núm. 43)

Dramáticos contemporáneos de Lope de Vega, colección escogida y ordenada, con un discurso, apuntes biográficos y críticos de los autores, noticias biográficas y catálogos de Ramón de Mesonero Romanos, Madrid, M. Rivadeneyra, Tomo 2, 1858, 603 págs. (Colección Biblioteca de Autores Españoles, núm. 45)

Dramáticos posteriores a Lope de Vega, colección escogida y ordenada con un discurso, apuntes biográficos y críticos de los autores, noticias biográficas y catálogos por Ramón de Mesonero Romanos, Madrid, M. Rivadeneyra, Tomo 1, 1858, 620 págs. (Colección Biblioteca de Autores Españoles, núm. 47)

Dramáticos posteriores a Lope de Vega, colección escogida y ordenada con un discurso, apuntes biográficos y críticos de los autores, noticias bibliográficas y catálogos por Ramón de Mesonero Romanos, Madrid, M. Rivadeneyra, Tomo 2, 1859, 654 págs. (Colección Biblioteca de Autores Españoles, núm. 49) 
Drieu la Rochelle, Pierre, Interrogation. Poèmes, Paris, Nouvelle Revue Française, 1917, 101 págs.

Duhamel, Georges, Compagnons. Poèmes, Paris, Nouvelle Revue Française, 1918, 125 págs.

Duhamel, Georges, Fables de mon Jardin, Paris, Mercure de France, 1936, 229 págs.

Duhamel, Georges, L'Humaniste et l'automate, Paris, Paul Hartmann, 1933, 201 págs. [32 photographies de Jean Roubier]

Duhamel, Georges, Les Poètes et la Poésie. 1912-1913. La connaissance poétique. Le choix d'un sujet. Sur la sincérité des poètes. De l'orgueil. De l'éclectisme. Petit tableau des écoles poétiques. D'un programme critique. Les poètes, Paris, Mercure de France, 1914, 338 págs.

Duhamel, Georges, Lettres au Patagon, París, Mercure de France, 1926, 222 págs.

Duhamel, Georges y Vildrac, Charles, Notes sur la technique poétique, París, Eugène Figuière, 1910, 71 págs. (Colección Oeuvres et Jours)

Durán, Agustín, Cancionero y romancero de coplas y canciones de Arte Menor. Letras, letrillas, romances cortos y glosas anteriores al siglo XVIII pertenecientes a los géneros Doctrinal, Amatorio, Jocoso, Satírico, etc., Madrid, Imprenta de Eusebio Aguado, 1829, 224 págs.

Durán, Agustín, Romancero de romances caballerescos e históricos anteriores al siglo XVIII que contiene los de Amor, los de la Tabla Redonda, los de Carlo Magno y los Doce Pares, los de Bernardo del Carpio, del Cid Campeador, de los Infantes de Lara, etc., ordenado y recopilado por Agustín Durán, Madrid, Imprenta don Eusebio Aguado, 1832, 247 págs. [Parte II]

Durán, Agustín, Romancero de romances doctrinales, amatorios, festivos, jocosos, satíricos, y burlescos sacados de varias colecciones generales y de las obras de diversos poetas de los siglos XV, XVI y XVII, Madrid, Imprenta de D. L. Amarita, 1829, 329 págs.

Durtain, Luc, Douze cent mille, París, Nouvelle Revue Française, 1922, 267 págs.

Durtain, Luc, Vers la ville kilomètre 3, s.l., Ernest Flammarion, 1933, 282 págs.

Eckermann, Juan Pedro, Conversaciones con Goethe en los últimos años de su vida (1822-1832), trad. J. Pérez Bances, Madrid, Calpe, Tomo 3, 1920, 346 págs. [Tomo Ill y último] (Colección Universal, núm. 283-286)

Eckermann, Juan Pedro, Conversaciones con Goethe en los últimos años de su vida (1828-1832), trad. J. Pérez Bances, Madrid, Calpe, Tomo 2, 1920, 329 págs. (Colección Universal, núm. 265-268)
Eguía Ruiz, Constancio, Literaturas y Literatos. Estudios Contemporáneos, Madrid, Sáenz de Jubera Hermanos, 1914, 460 págs. [Primera serie]

"El retablo de Maese Pedro", en Nueva edición crítica de "El Ingenioso Hidalgo". Capítulo XXVI de la segunda parte del "Quijote", anotación de Francisco Rodríguez Marin, Madrid, Tipografía de la Revista de Archivos, Bibliotecas y Museos, 1928, 32 págs.

"El romance del cura", en Nueva edición crítica de "El Ingenioso Hidalgo". Apéndice XXII del tomo último del "Quijote", Madrid, s.n., 1928, 32 págs.

Entrambasaguas, Joaquín de, El doctor don Cristóbal Lozano, de Revista de Archivos, Bibliotecas y Museos, Madrid, Tipografía de la Revista de Archivos, Bibliotecas y Museos, 1927, 143 págs.

Epistolario español. Colección de cartas de españoles ilustres antiguos y modernos, recogida y ordenada con notas y aclaraciones históricas, críticas y biográficas por don Eugenio de Ochoa, Madrid, M. Rivadeneyra, Tomo 1, 1872, 644 págs. (Colección Biblioteca de Autores Españoles, núm. 13)

Epistolario español. Colección de cartas de españoles ilustres antiguos y modernos, recogida y ordenada con notas y aclaraciones históricas, críticas y biográficas por don Eugenio de Ochoa, Madrid, M. Rivadeneyra, Tomo 2, 1870, 638 págs. (Colección Biblioteca de Autores Españoles, núm. 62)

Escritores del siglo XVI. 1. San Juan de la Cruz; Fray Pedro Malón de Chaide; Fray Hernando de Zarate, Madrid, M. Rivadeneyra, Tomo 1, 1853, 684 págs. (Colección Biblioteca de Autores Españoles, núm. 27)

Escritores Misticos Españoles. 1. Fernando de Herrera. Alejo Venegas, Francisco de Osuna, Alfonso de Madrid, con un discurso preliminar de Miguel Mir, Madrid, Bailly Bailliére, Tomo 1, 1911, 657 págs. (Colección Los clásicos olvidados. Nueva Biblioteca de Autores Españoles, núm. 16)

Espina Garcia, Antonio, Luna de copas. Novela, Madrid, Revista de Occidente, 1929, 158 págs.

Espina Garcia, Antonio, Signario. Versos, Madrid, s.n., 1923, 92 págs. (Colección Biblioteca de Índice, núm. 4)

Espinel, Vicente, Vida de Marcos de Obregón, edición y anotación de Samuel Gili y Gaya, Madrid, Ediciones La Lectura, Vol. 1, 1922, 330 págs. (Colección Clásicos Castellanos, núm. 43)

Espinel, Vicente, Vida de Marcos de Obregón, edición de Samuel Gili y Gaya, Madrid, La Lectura, Vol. 2, 1923, 346 págs. (Colección Clásicos Castellanos, núm. 51)

ARBOR CLXXXVI 744 julio-agosto [2010] 739-776 ISSN: 0210-1963 
Espronceda, José de, El Diablo Mundo, edición y anotación de José Moreno Villa, Madrid, Ediciones La Lectura, Vol. 2, 1923, 282 págs. (Colección Clásicos Castellanos, núm. 50)

Espronceda, José de, Obras poéticas. 1. Poesías y El estudiante de Salmanca, edición y prólogo de José Moreno Villa, José, Madrid, Ediciones La Lectura, Vol. 1, 1923, 343 págs. (Colección Clásicos Castellanos, núm. 47)

Espronceda, José de, Poesie Scelte, introducción y anotación de Pilade Mazzei, Milano, Carlo Signorelli, 1927, 102 págs.

Estelrich, Joan, Entre la vida i els Llibres, Barcelona, Librería Catalònia, 1926, 344 págs. [Assaigs. Vol. 4] (Colección El Ram d'Olivera, núm. 2)

Estelrich, Joan, La qüestió de les minories nacionals. 1. Les vies del dret, Barcelona, Llibreria Catalònia, Tomo 1, 1929, 372 págs. (Colección Biblioteca d'estudis econòmics, socials i politics, núm. 2)

Estrada, Genaro, Crucero. Poemas, México, Editorial Cultura, 1928, 88 págs.

Estrada, Genaro, Paso a nivel, Madrid, Ediciones Héroe, 1933, 74 págs.

Estrella Gutiérrez, Fermin, Los caminos del mundo, Buenos Aires, Agencia General de Libreria y Publicaciones, 1929, 141 págs.

Faguet, Émile, Flaubert, París, Hachette, 1922, 191 págs. (Colección Les grands écrivains français)

Faure-Biguet, Jacques Napoleón, Montherlant. Homme de la Reinaissance, París, Librairie Plon, 1925, 73 págs.

Feijóo, Benito Jerónimo, Cartas eruditas, edición, prólogo y notas de Agustín Millares Carlo, Madrid, Ediciones La Lectura, Vol. 4, 1928, 269 págs. (Colección Clásicos Castellanos, núm. 85)

Feijóo, Benito Jerónimo, Teatro crítico universal, edición, prólogo y notas de Agustín Millares Carlo, Madrid, Ediciones La Lectura, Vol. 1, 1923, 335 págs. (Colección Clásicos Castellanos, núm. 48)

Feijóo, Benito Jerónimo, Teatro crítico universal, edición, selección y notas de Agustín Millares Carlo, Madrid, Ediciones La Lectura, Vol. 2, 1924, 300 págs. (Colección Clásicos Castellanos, núm. 53)

Feijóo, Benito Jerónimo, Teatro crítico universal, edición y prólogo de Agustín Millares Carlo, Madrid, Ediciones La Lectura, Vol. 3, 1925, 330 págs. (Colección Clásicos Castellanos, núm. 67)

Fernández Ardavín, Luis, El Doncel Romántico, Madrid, Biblioteca Hispania, 1922, 248 págs. [Folletín escénico en cinco capítulos y en verso, estrenado en el teatro de la princesa el día 18 de noviembre de 1922]

Fernández Ardavín, Luis, Meditaciones y otros poemas, prólogo de Enrique Díez Canedo, Madrid, Imprenta Progreso Gráfico, 1913, 190 págs. [Óleos de César Fernández Ardavín]
Fernández de Moratín, Nicolás y Fernández de Moratín, Leandro, Obras, Madrid, M. Rivadeneyra, 1857, 636 págs. (Colección Biblioteca de Autores Españoles, núm. 2)

Fernández Gordillo, Manuel, Cantares de los fuegos, Madrid, Sucesores de Rivadeneyra, 1926, 124 págs.

Fernández Montesinos, José, Cadalso o la noche cerrada, Madrid, Cruz y Raya, 1934, 67 págs.

Fernández Vallejo, Paulino, Las armonías inefables, Madrid, Biblioteca Partenón, 1917, 172 págs.

Fernández, Francisco Luis, Alcándara. Imágenes, Buenos Aires, Proa, 1925, 106 págs.

Ferreras, Margarita, Pez en la tierra. Con un prólogo de B. Jarnés, Madrid, Imprenta Concha Méndez y Manuel Altolaguirre, 1932, 87 págs.

Figueira, Gastón, En el templo de la noche, Buenos Aires. París, Cabaut y Cía, 1926, 173 págs.

Figueiredo, Fidelino de, Historia da Litteratura Romantica Portuguesa (1825-1870), Lisboa, Livraria Classica Editora, Tomo 4 1913, 208 págs. (Colección Bibliotheca de estudios histórico nacionaes)

Figueras Pacheco, Francisco, Volutas de fuego. Poesías, Alicante, Imprenta Lucentum, 1928, 158 págs.

Fitzmaurice-Kelly, James, Bibliographie de l'Histoire de la Littérature espagnole, Paris, Librairie Armand Colin, 1913, 78 págs.

Floresta de leyendas heroicas españolas. Rodrigo, el último Godo. 3. La Edad Moderna, comp. Ramón Menéndez Pidal, Madrid, Ediciones La Lectura, Tomo 3, 1927, 306 págs. (Colección Clásicos Castellanos, núm. 84)

Floresta de leyendas heroicas españolas. Rodrigo, el último Godo, comp. Ramón Menéndez Pidal, Madrid, Ediciones La Lectura, Tomo 2, 1926, 258 págs. (Colección Clásicos Castellanos, núm. 71)

Floresta de leyendas heroicas españolas. Rodrigo, el último Godo. 1. La Edad Media, comp. Ramón Menéndez Pidal, Madrid, Ediciones La Lectura, Tomo 1, 1925, 301 págs. (Colección Clásicos Castellanos, núm. 62)

Flouquet, Pierre-Louis, Corps et ame, La Louvière (Belgique), Les cahiers du Journal des Poètes, 1933, 94 págs.

Fogazzaro, Antonio, Daniel Cortis. Novela, trad. Cipriano Rivas Cherif, Madrid, Calpe, Tomo 1, 1920, 315 págs. (Colección Universal, núm. 278-280)

Fogazzaro, Antonio, Daniel Cortis. Novela, trad. Cipriano Rivas Cherif, Madrid, Calpe, Tomo 2, 1920, 158 págs. (Colección Universal, núm. 299-300)

Fondane, Benjamin, Ulysse, Bruxelles, Les cahiers du Journal des Poètes, 1933, 75 págs. 
Forner, Juan Pablo, Exequias de la lengua castellana, edición y anotación de Pedro Sainz Rodríguez, Madrid, Ediciones La Lectura, 1925, 294 págs. (Colección Clásicos Castellanos, núm. 66)

Fort, Paul, Anthologie de l'effort, Poitiers, Éditions de l'Effort, 1912, 183 págs.

Fouillée, Alfredo, Temperamento y carácter según los individuos, los sexos y las razas, trad. Ricardo Rubio, Madrid, Hermanos Sáenz de Jubera. Fernando Fe, 1901, 321 págs.

Frédérix, Pierre, Goya, París, L'artisan du livre, 1928, 167 págs. [Avec vingt-quatre illustrations hors texte]

Frédérix, Pierre, L'Ange et la Couronne. Roman, París, CalmannLévy, 1927, 225 págs.

Gallardo, Bartolomé José, Obras escogidas de don Bartolomé José Gallardo, edición, prólogo y notas de Pedro Sainz Rodríguez, Madrid, CIAP, Tomo 1, 1928, 266 págs. (Colección Los clásicos olvidados. Nueva Biblioteca de Autores Españoles)

Gallardo, Salvador, El Pentagrama-Eléctrico. Poemas de Salvador Gallardo, México, Germán List Arzubide, 1925

Gallego y Burín, Antonio, "Pedro de Mena y el misticismo español", en Boletín de la Universidad de Granada, núm. 7, Granada, Tipografía Paulino Ventura Traveset, 1930, 28 págs.

Gaos, Alejandro, Tertulia de Campanas, Madrid, Ediciones Ulises, 1932, 60 págs.

Garcés, Tomás, Notes sobre poesía, Barcelona, Altés, 1933, 142 págs.

Garcés, Tomás, Paradís, Barcelona, Altés, 1931, 66 págs.

Garcia Cabrera, Pedro, Transparencias Fugadas. Poemas, Tenerife, Gaceta del Arte, 1934, 30 págs.

García Calderón, Ventura, Del romanticismo al modernismo. Prosistas y poetas peruanos, París, Librería P. Ollendorff, ¿1910?, 545 págs.

Garcia Calderón, Ventura, Une enquête littéraire: Don Quichotte a Paris et dans les tranchées, Paris, s.n., 1916, 100 págs. (Colección Centre d'Études Franco-hispaniques de I'Université de Paris)

García Marti, Victoriano, De la zona atlántica, Galicia y Portugal. Ensayos, Madrid, Sociedad General Española de Librería, 1934, 204 págs.

Garcilaso de la Vega, Inca, Obras, edición y anotación de Tomás Navarro Tomás, Madrid, Ediciones La Lectura, 1924, 269 págs. (Colección Clásicos Castellanos, núm. 3)

Gautier, Teófilo, Viaje por España, trad. Enrique de Mesa, Madrid, Calpe, Tomo 2, 1920, 270 págs. (Colección Universal, núm. 346-348)

Ghiraldo, Alberto, Antología americana. 5. Anecdotario, Madrid, Renacimiento, Vol. 5, ¿1923?, 292 págs.
Gil-Albert, Juan, Gabriel Miró. El escritor y el hombre, Valencia, S.n., 1931, 56 págs. [Figuras españolas número 2] (Colección Cuadernos de Cultura, núm. 27)

Giménez Caballero, Ernesto, El Belén de Salzillo en Murcia. Origen de los Nacimientos en España, Madrid, Ediciones de La Gaceta Literaria, 1934, 134 págs. [Con ocho ilustraciones]

Giner de los Ríos, Francisco, Obras completas de don Francisco Giner de los Ríos. 2. La Universidad Española, Madrid, Imprenta Clásica Española, Tomo 2, 1916, 301 págs.

Goethe, Johann Wolfgang von, Memorias de mi vida. Poesias y verdad, trad. José Pérez Bances, Madrid, Calpe, Tomo 1, 1922, 270 págs. (Colección Universal, núm. 692-694)

Goethe, Johann Wolfgang von, Teatro selecto de Juan Wolfgang Goethe, trad. Fanny G. Garrido de Rodríguez Mourelo, Madrid, Librería de Perlado, Páez y Compañía. Sucesores de Hernando, Tomo 1, 1922, 293 págs. (Colección Biblioteca Clásica, núm. 178)

Goldoni, Carlo, La Locandiera. Comedia, prólogo de Fernando González, Madrid, CIAP, s.a., 254 págs. (Colección Las cien mejores obras de la literatura universal, núm. 49)

Gómez de Baquero, Eduardo, Obras completas. 2. Pen club. I. Ios poetas, Madrid, CIAP-Renacimiento, Vol. 2, 1929, 368 págs.

Gómez de la Serna, Ramón, El Circo, Portada de Bartolozzi, Madrid, Imprenta Latina, s.a., 128 págs.

Gómez de la Serna, Ramón, El teatro en soledad. Drama en tres actos, s.l., ¿Prometeo?, s.a.

Gómez de la Serna, Ramón, La veuve blanche et noire, trad. Jean Cassou, París, Éditions du Sagittaire, 1924, 261 págs. (Colección de la Revue Européenne, núm. 8)

Gómez, Miguel Ángel, La rosa sobre los vientos, Buenos Aires, M. Gleizer, 1934

González Martínez, Enrique, Poesía. 1909-1929, Madrid, Espasa Calpe, ¿1929?, 299 págs.

González Rojo, Enrique, Espacio. Poemas, Madrid, Mundo Latino, 1926, 192 págs.

González, Fernando, Hogueras en la montaña. Poesías (19171923), Madrid, Librería de Alejandro Pueyo. Imprenta Clásica Española, 1924, 158 págs.

González, Fernando, Manantiales en la Ruta. Poesías (1918-1921), versos iniciales por Tomás Morales, retrato del poeta por Victorio Macho, Madrid, Tipografía Artística, 1923, 155 págs.

González, Fernando, Piedras Blancas. Poesías, Madrid, Imprenta Sáez Hermanos, 1934, 148 págs.

Gorki, Maximo y Block, Alexander, La canción del Halcón y la canción del Albatros, trad. Salomón Kahan, México, Cultura,

ARBOR CLXXXVI 744 julio-agosto [2010] 739-776 ISSN: 0210-1963

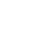

(n)


Tomo 1, 1922, 60 págs. [Número 1. Alexander Block es autor de "Los Doce", también incluido aqui] (Colección Biblioteca Universo, núm. 1)

Gorki, Maximo, Varenka Olesova. Novela, trad. N. Tasin, Madrid, Barcelona, Calpe, 1920, 160 págs. (Colección Universal, núm. 121-122)

Gourmont, Remy de, La fin de l'art, París, s.n., 1925, 125 págs. [Première série] (Colección Les Cahiers de Paris, núm. 8)

Gramática de la lengua española, Madrid, Real Academia Española-Espasa Calpe, 1931, 534 págs.

Grasset, Bernard, El Món dels Llibres, trad. Just Cabot, Barcelona, A. López Llausàs, 1929, 180 págs.

Grau, Jacinto, El señor de Pigmalión. Farsa tragicómica de hombres y muñecos, en tres actos y un prólogo, ilustraciones de Salvador Bartolozzi, Madrid, s.n., 1928, 83 págs. [Año II. Junio de 1928] (Colección La Farsa, núm. 40)

Guérin, Charles, Le Semeur de Cendres 1898-1900, Paris, Mercure de France, 1909, 224 págs.

Gutiérrez Gili, Juan, Surco y Estela, Barcelona, Hijo de Miguel Casals, 1925, 46 págs.

Halcón, Manuel, Fin de raza, Sevilla, Tipografía Manuel Carmona de los Ríos, 1927, 138 págs.

Hazard, Paul, La vie de Stendhal, París, Librairie Gallimard, Éditions de la Nouvelle Revue Française, 1928, 254 págs. (Colección Vies des hommes illustres, núm. 11)

Heine, Heinrich, Cuadros de viajes, primera versión castellana hecha directamente del alemán con arreglo al texto revisado y completado por Adolfo Strodtmann, anotada y comparada con la versión francesa del autor por Lorenzo González Aguejas. Con un ensayo biográfico y crítico acerca del autor y sus obras, Madrid, Librería de Perlado, Páez y Compañia. Sucesores de Hernando, Tomo 1, 1916, 310 págs. (Colección Biblioteca Clásica, núm. 124)

Heine, Heinrich, Cuadros de viaje, primera versión castellana hecha directamente del alemán con arreglo al texto revisado y completado por Adolfo Strodtmann, anotada y comparada con la versión francesa del autor por Lorenzo González Agejas. Con un ensayo biográfico y crítico acerca del autor y sus obras, Madrid, Librería de los sucesores de Hernando, Tomo 2, 1916, 408 págs. (Colección Biblioteca Clásica, núm. 126)

Heine, Heinrich, Cuadros de viaje, primera versión castellana hecha directamente del alemán con arreglo al texto revisado y completado por Adolfo Strodtmann, anotada y comparada con la versión francesa del autor por Lorenzo González Agejas. Con un estudio de Renato Doumic sobre la poesía de Heine. Apéndice seguido de la traducción en verso del Intermedio Lírico, Madrid, Librería de los sucesores de Hernando, Tomo 3, 1906, 401 págs. (Colección Biblioteca Clásica, núm. 215)

Heine, Heinrich, Memorias, trad. Manuel Pedroso, Madrid, Calpe, 1920, 103 págs. (Colección Universal, núm. 214)

Hendrix, William S., Las Rimas de Bécquer y la influencia de Byron, Madrid, Tipografía de Archivos, 1931, 47 págs.

Henríquez Ureña, Max, El retorno de los galeones. Bocetos hispánicos, Madrid, CIAP-Renacimiento, 1930, 259 págs.

Henríquez Ureña, Pedro, "Apuntaciones de la novela en América", en Humanidades, Buenos Aires, Imprenta y Casa editora "Coni", Tomo 15, 1927, 16 págs. [Páginas 133 a 146]

Heredia, Nicolás, La sensibilidad en la poesía castellana, Madrid, Sociedad Española de Librería, ¿1900?, 298 págs. (Colección Biblioteca Andrés Bello)

Hernández, Alejo, Farsa de Estudiantina. Poema de la clásica vida escolar española, Madrid, Imprenta Sáez Hermanos, 1930, 83 págs. [Ilustraciones de Rivadulla]

Hernández, José A., Tren, s.l., s.n., ¿1931?, 23 págs.

Herrera y Reisig, Julio, Las Pascuas del tiempo, Madrid, Editorial América, 1920, 156 págs. (Colección Biblioteca Andrés Bello)

Herrero, Bernabé, Letrillas Castellanas, Madrid, Gráficas Morales, 1934, 129 págs.

Hinojosa, José María, La flor de California, prólogo de José Moreno Villa, Madrid/Málaga, Imprenta Sur, 1928, 132 págs. [Dibujos de J. Peinado] (Colección Nuevos novelistas españoles)

Hinojosa, José Maria, La rosa de los vientos. 1926, Málaga, Imprenta Sur, 1927, 44 págs. [7 Suplemento de Litoral]

Hinojosa, José María, Poema del campo. 1924, portada y retrato del autor por Salvador Dalí, Madrid, Imprenta Maroto, 1925, 64 págs.

Hinojosa, José Maria, Poesía de perfil. 1925, con cuatro dibujos por Manuel Ángeles Ortiz, París, Imprenta Le Moil \& Pascaly, 1926, 92 págs.

Hispano, Cornelio, Elegías Caucanas, París, Librería P. Ollendorff, 1912, 249 págs.

Historiadores de Indias. 1. Apologética historia de las Indias de Fray Bartolomé de las Casas, por Serrano y Sanz, Madrid, Bailly Bailliére, Tomo 1, 1909, 704 págs. (Colección Los clásicos olvidados. Nueva Biblioteca de Autores Españoles, núm. 13)

Historiadores de Indias. 2. Guerra de Quito, de Pedro de Lieza de León, Jornada del Río Marañón, de Toribio de Ortiguera, Jornada de Amagua y Dorado, Descripción del Perú, Lucumán, Río de la Plata y Chile, de Fr. Reginaldo de Lizárraga, por 
Serrano y Sanz, Madrid, Bailly Bailliére, Tomo 2, 1909, 678 págs. (Colección Los clásicos olvidados. Nueva Biblioteca de Autores Españoles, núm. 15)

Homenaje ofrecido a Menéndez Pidal. Miscelánea de estudios lingüisticos, literarios e históricos, Madrid, Librería y Casa editorial Hernando, Tomo 3, 1925, 696 págs.

Homero, La llíada, trad. Gómez Hermosilla, José, Madrid, Librería de los sucesores de Hernando, Tomo 1, 1923, 376 págs. (Colección Biblioteca Clásica, núm. 1)

Homero, La llíada, trad. José Gómez Hermosilla, Madrid, Librería de Perlado, Páez y Compañia. Sucesores de Hernando, Tomo 2, 1924, 430 págs. (Colección Biblioteca Castellana, núm. 2)

Homero, La llíada, trad. José Gómez Hermosilla, Madrid, Librería de los sucesores de Hernando, Tomo 3, 1924, 302 págs. (Colección Biblioteca Clásica, núm. 3)

Homero, La Odisea, trad. Federico Baráibar y Zumárraga, Madrid, Librería de Perlado, Páez y Compañía. Sucesores de Hernando, Tomo 1, 1922, 363 págs. (Colección Biblioteca Clásica, núm. 95)

Homero, La Odisea. 2. La batracomiomaquia, trad. Federico Baráibar y Zumárraga y Jenaro Alenda, Madrid, Librería de Perlado, Páez y Compañia. Sucesores de Hernando, Tomo 2, 1922, 324 págs. (Colección Biblioteca Clásica, núm. 96)

Hommage des écrivains étrangers à Paul Valéry, Maestricht, Stols, 1927, 242 págs.

Huidobro, Vicente, Adán. Poema, Santiago, Imprenta Universitaria, 1916, 126 págs.

Huizinga, Johan, El otoño de la Edad Media, trad. José Gaos, Madrid, Revista de Occidente, Tomo 2, 1930, 276 págs.

Hurtado y J. de la Serna, Juan y González Palencia, Ángel, Historia de la literatura española, Madrid, Tipografía de la Revista de Archivos, Bibliotecas y Museos, 1921, 480 págs.

Hurtado y J. de la Serna, Juan y González Palencia, Ángel, Antología de la literatura española, Madrid, Imprenta del Seminario Conciliar, 1926, 586 págs.

Ibarbourou, Juan de, La rosa de los vientos, Montevideo/ Buenos Aires, Palacio del Libro, 1930, 125 págs.

Icaza, Francisco A. de, Antología crítica de poetas extranjeros. Christian Friedich Hebbel, Madrid, Juan Pueyo, 1919 [Ilustraciones de F. Marco, R. Marín]

Icaza, Francisco A. de, La canción del camino, Madrid, Tipografía Sucesores de Rivadeneyra, 1905, 108 págs.

Icaza, Francisco A. de, Sucesos reales que parecen imaginados de Gutierre de Cetina, Juan de la Cueva y Mateo Alemán, referidos y comentados Francisco A. de Icaza, s.l., Sucesores de Hernando, 1919, 267 págs.
Icaza, Xavier, Magnavoz 1926. Discurso Mexicano, Xalapa, Talleres Gráficos del Gobierno de Veracruz, 1926, 47 págs.

Ipuche, Pedro Leandro, Isidoro Luciano Ducasse (Conde de Latréamont). Poeta Uruguayo, Montevideo, Imprenta Hnos. Peña, 1926, 16 págs.

Ipuche, Pedro Leandro, Júbilo y miedo, Montevideo, Agencia General de Librería y Publicaciones, 1926, 125 págs. [Maderas de Melchor Méndez Magariños]

Iriarte, María Luisa de, Romances de amor antiguo y otras composiciones, Madrid, Reus, 1933, 95 págs.

Isla, José Francisco de, Obras escogidas del Padre José Francisco de Isla, con una noticia de su vida y escritos por don Pedro Felipe Monlau, Madrid, M. Rivadeneyra, 1850, 632 págs. (Colección Biblioteca de Autores Españoles, núm. 15)

Iturburu, Cordova, La danza de la luna, México-Buenos Aires, Sociedad de Publicaciones El Inca. Ediciones especiales, 1926, 120 págs.

Izquierdo, José María, Relieves... sin relieve. Reportes de un reportero... inactual. Artículos de Jacinto Ilusión, Iván el imbécil, Santor Resartus, Heautontimorumenos, Lévy, Escayo, Escevo, Leftlint, Ezquerre, Postman, Halcyon, Xemar, Amaro..., Sevilla, Tipografía Zarzuela, 1919, 149 págs.

Jacob, Max, L'homme de chair et l'homme reflet, Paris, Éditions du Sagittaire, Tomo 7, 1924, 256 págs. (Colección De la Revue Européenne, núm. 7)

Jammes, Francis, De l'Angelus de l'aube à l'Angelus du soir. 18881897, París, Société du Mercure de France, 1906, 345 págs.

Jammes, Francis, Del toque de alba al toque de oración, trad. Enrique Díez Canedo, Madrid, Calpe, 1920, 245 págs. (Colección Los poetas)

Jarnés, Benjamín, Ejercicios, Madrid, Cuadernos Literarios, 1927, 92 págs.

Jarnés, Benjamin, El profesor inútil, Madrid, Revista de Occidente, 1926, 155 págs. (Colección Nova Novorum)

Jarnés, Benjamín, El profesor inútil, Madrid, Espasa Calpe, 1934, 259 págs.

Jarnés, Benjamín, Feria del libro, Madrid, Espasa Calpe, 1935, 295 págs.

Jarnés, Benjamin, Libro de Esther, Madrid, Espasa Calpe, 1935, 204 págs.

Jarnés, Benjamín, Rúbricas. Nuevos ejercicios, Madrid, Biblioteca Atlántico, 1931, 174 págs.

Jarnés, Benjamín, Viviana y Merlín. Leyenda, Madrid-Buenos Aires, CIAP-Ediciones Ulises, 1930, 203 págs. (Colección Valores actuales)

ARBOR CLXXXVI 744 julio-agosto [2010] 739-776 ISSN: 0210-1963

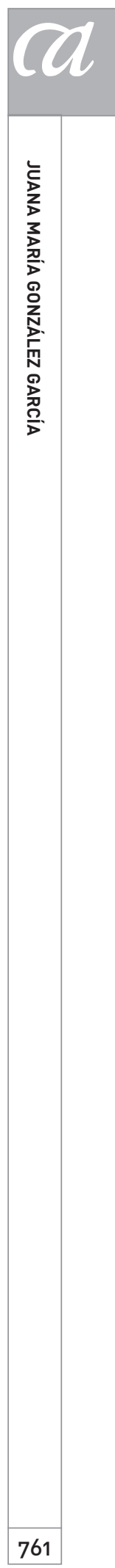

doi: $10.3989 /$ arbor. 2010.744 n1230 
Jean-Paul, Choix de Rêves, trad. Albert Béguin, Paris, Éditions Fourcade, 1931, 210 págs. (Colección Confessions Spirituelles, núm. 1)

Jiménez, Guillermo, Constanza, Madrid, Rafael Caro Raggio, 1921, 48 págs.

Jiménez, Juan Ramón, Elegías. 2. Elegías Intermedias 1908, Madrid, Tipografía de la Revista de Archivos, Vol. 2, 1909, 76 págs.

Jiménez, Juan Ramón, Segunda Antolojía poética, 1898-1918, Madrid, Calpe, 1922, 356 págs. (Colección Universal, núm. 688-691)

Jiménez, Max, Gleba, París, Le Livre Libre, 1929, 116 págs.

Jovellanos, Gaspar Melchor de, Obras escogidas, edición, introducción y notas de Ángel del Río, Madrid, Espasa Calpe, Vol. 1, 1935, 288 págs. (Colección Clásicos Castellanos, núm. 110)

Jovellanos, Gaspar Melchor de, Obras escogidas, Madrid, Espasa Calpe, Vol. 2, 1935, 241 págs. (Colección Clásicos Castellanos, núm. 111)

Jovellanos, Gaspar Melchor de, Obras publicadas e inéditas, colecc. Nocedal, Cándido, ilustr. Nocedal, Cándido, Madrid, M. Rivadeneyra, Tomo 1, 1858, 624 págs. (Colección Biblioteca de Autores Españoles, núm. 46)

Jovellanos, Gaspar Melchor de, Obras publicadas e inéditas, colección e ilustraciones de Cándido Nocedal, Madrid, M. Rivadeneyra, Tomo 2, 1859, 548 págs. (Colección Biblioteca de Autores Españoles, núm. 50)

Joyce, James, El artista adolescente, trad. Alfonso Donado, prólogo de Antonio Marichalar, Madrid, Biblioteca Nueva, 1926, 338 págs.

Juan de la Cruz, Santo, El cántico espiritual según el ms. de las madres carmelitas de Jaén, edición y anotación de M. Martínez Burgos, Madrid, Ediciones La Lectura, 1924, 360 págs. (Colección Clásicos Castellanos, núm. 55)

Keyserling, Hermann, El mundo que nace, trad. Ramón Maria Tenreiro, Madrid, Revista de Occidente, 1930, 181 págs. (Colección Nuevos hechos. Nuevas ideas, núm. 11)

"La pobreza de los hidalgos", en Nueva edición crítica de "El Ingenioso Hidalgo". Apéndice XXXVI del tomo último del "Quijote", anotación de Francisco Rodríguez Marín, Madrid, Tipografía de la Revista de Archivos, Bibliotecas y Museos, 1928, 18 págs.

La verdadera poesía castellana. Floresta de la antigua lírica popular, recogida y estudiada por Julio Cejador y Frauca, Madrid, Tipografía de la Revista de Archivos, Bibliotecas y Museos, Tomo 1, 1921, 302 págs.

Lacalle, Ángel, Mio Cid. Glosas, Madrid, Tipografía de J. Pérez Torres, s.a., 80 págs.
Lacomba, Juan, Carácter. Poemas, Valencia, s.n., 1928, 44 págs. (Colección Puerto, núm. 1)

Laffón, Rafael, Signo + Poemas, Sevilla, s.n., 1927, 69 págs. (Colección Mediodia)

Lafora, Gonzalo R., "Ensayo psicológico sobre la inspiración poética", en Humanidades, Buenos Aires, Imprenta y Casa editora "Coni", Tomo 7, 1923, 22 págs. [Páginas 9 a 28]

Laguna, Maria F. de la, Arco Iris, Londres, La tentativa poética, 1935, 29 págs.

Lahy-Hollebecque, M., Les Charmeurs d'enfants, París, Baudinière, 1928, 286 págs. [Préface de M. Edouard Herriot]

Lalou, René y Weidlé, Wladimir, Paul Valéry. Textes suivis de débats, París, Chaiers de la Quinzaine, 1930, 76 págs.

Lamandé, André, L'Espagne écartelée, París, Éditions des portiques, s.a., 250 págs.

Larbaud, Valery, Fermina Márquez, Paris, Plon-Nourrit et Cie, ¿1911?, 169 págs. (Colección Bibliothèque Plon)

Larra, Mariano José de, Artículos de crítica literaria y artística, prólogo y notas de José Ramón Lomba y Pedraja, Madrid, Ediciones La Lectura, Vol. 2, 1923, 317 págs. (Colección Clásicos Castellanos, núm. 52)

Lemonnier, León, Manifeste du roman populiste, París, La Centaine, 1929, 81 págs.

Lenz, Rodolfo, De la ortografía castellana, Valparaíso, Franzisko Enrríkez, 1914, 60 págs.

León Felipe, Drop a Star. Poema, México, Imprenta Artística de José Celorio Ortega, 1933, 28 págs.

Les Haïkaï de Kikakou, trad. Kuni Matsuo, textes et commentaires japonais traduits pour la première fois par Kuni Matsuo et Steinilber-Oberlin, París, Les Éditions G. Crès et Cie, 1927, 341 págs.

Leseur, Élisabeth, Journal et pensées de chaque jour, précédés d'une lettre du R. P. Javier, O. P., París, J. de Gigord, 1927, 338 págs.

Lira, Miguel M., Corrido de Domingo Arenas, Méjico, Alcancia, 1932, 46 págs.

Lira, Miguel M., Segunda Soledad, México, Fábula, 1933, 63 págs.

List Arzubide, Germán, El movimiento estridentista, República Mexicana, Ediciones de Horizonte, 1927, 106 págs.

Lista, Alberto, Poesías inéditas, edición y estudio preliminar de José María de Cossío, Madrid, Voluntad, 1927, 423 págs. (Colección Sociedad de Menéndez y Pelayo)

Livio, Tito, Décadas de la Historia romana, trad. Francisco Navarro y Calvo, Madrid, Librería y Casa editorial Hernando, Tomo 1, 1928, 346 págs. (Colección Biblioteca Clásica, núm. 111) 
Livio, Tito, Décadas de la Historia romana, trad. Francisco Navarro y Calvo, Madrid, Librería y Casa editorial Hernando, Tomo 2, 1929, 328 págs. (Colección Biblioteca Clásica, núm. 112)

Livio, Tito, Décadas de la Historia romana, trad. Francisco $\mathrm{Na}$ varro y Calvo, Madrid, Librería y Casa editorial Hernando, Tomo 3, 1929, 414 págs. (Colección Biblioteca Clásica, núm. 115)

Livio, Tito, Décadas de la Historia romana, trad. Francisco Navarro y Calvo, Madrid, Librería de los sucesores de Hernando, Tomo 5, 1915, 432 págs. (Colección Biblioteca Clásica, núm. 118)

Livio, Tito, Décadas de la Historia romana, trad. Francisco Navarro y Calvo, Madrid, Librería de los sucesores de Hernando, Tomo 6, 1914, 439 págs. (Colección Biblioteca Clásica, núm. 121)

Livio, Tito, Décadas de la Historia romana, trad. Francisco Navaro y Calvo, Madrid, Librería de Perlado, Páez y Compañia. Sucesores de Hernando, Tomo 7, 1917, 450 págs. (Colección Biblioteca Clásica, núm. 122)

Llorca, Ángel, El primer año de lenguaje. Conversación, dibujo, escritura, lectura de lo escrito, trozos en prosa y verso de buenos autores para recitarlos, para frasearlos y para servir de modelo en las lecturas del maestro, canto,gramática, dictado-composición, etc., Madrid, Librería y Casa editorial Hernando, 1933, 291 págs. [Colección dirigida por Ángel Llorca] (Colección Libros de orientación escolar)

Llorca, Ángel, Los cuatro primeros años de Escuela Primaria. El maestro hace para que el niño haga. 4. Primera parte. Los cuatro primeros años de escuela primaria, Madrid, Librería y Casa editorial Hernando, Tomo 4, 1929, 259 págs. (Colección Libros de orientación escolar)

Lomba y Pedraja, José Ramón, El P. Arolas, su vida y sus versos. Estudio crítico, Madrid, Tipografía Sucesores de Rivadeneyra, 1898, 243 págs.

Lomba y Pedraja, José Ramón, Mariano José de Larra (Fígaro). Como escritor político y como crítico literario, Madrid, Imprenta de la Revista de Archivos, Bibliotecas y Museos, 1920, 99 págs.

López-Picó, Josep Maria, Antología lírica, prólogo de Carles Riba, epílogo de A. Esclasans, Barcelona, Imprenta Altés, 1931, 323 págs.

López-Picó, Josep María, Entre els ocells i els angels, Barcelona, Imprenta Altés, 1932, 62 págs. [0p. XXVI]

"Los rebuznadores", en Nueva edición crítica de "El Ingenioso Hidalgo". Apéndice XXIX del tomo último del "Quijote", anotación de Francisco Rodríguez Marín, Madrid, Tipografía de la Revista de Archivos, Bibliotecas y Museos, 1928, 18 págs.
Loüys, Pierre, Les Chansons de Bilitis, ilustrations d'après les dessins de A. Calbet, París, Modern-Bibliothéque. Arthème Fayard et Cie, ¿1922?, 93 págs. [Traduites du Grec.]

Ludovici, Anthony M., Lysistrata o el porvenir de la mujer y la mujer del porvenir, trad. José Ortega y Gasset, prólogo de Norman Haire, Madrid, Revista de Occidente, 1926, 126 págs. (Colección Hoy y mañana)

Luelmo, José María, Inicial. 1928-1929, Valladolid, Imprenta Carlos Martín, s.a., 72 págs. (Colección Meseta, núm. 1)

Luelmo, José María, Ventura preferida. Poemas, Madrid, Ediciones Héroe, 1936, 119 págs.

Luis de Granada, Fray, Guía de pecadores, ed. Matías Martínez Burgos, Madrid, Ediciones La Lectura, 1929, 299 págs. (Colección Clásicos Castellanos, núm. 97)

Luis de Granada, Fray, Obras, biografía y prólogo de José Joaquín de Mora, Madrid, M. Rivadeneyra, Tomo 3, 1849, 648 págs. (Colección Biblioteca de Autores Españoles, núm. 11)

Luis de León, Fray, De los nombres de Cristo, edición y anotación de Federico de Onís, Madrid, Ediciones de La Lectura, Vol. 1, 1914, 281 págs. (Colección Clásicos Castellanos, núm. 28)

Luis de León, Fray, De los nombres de Cristo, edición y anotación de Federico de Onís, Madrid, Ediciones La Lectura. Espasa Calpe, Vol. 2, 1931, 282 págs. (Colección Clásicos Castellanos, núm. 33)

Luis de León, Fray, De los nombres de Cristo, edición y anotación de Federico de Onís, Madrid, Ediciones La Lectura, Vol. 3, 1921, 259 págs. (Colección Clásicos Castellanos, núm. 41)

Luis de León, Fray, Escritores del siglo XVI. Obras del maestro Fray Luis de León, precédelas su vida, escrita por don Gregorio Mayans y Siscar y un extracto del proceso instruido contra el autor desde el año 1571 al 1576, Madrid, M. Rivadeneyra, Tomo 2, 1872, 491 págs. (Colección Biblioteca de Autores Españoles, núm. 37)

Luis de León, Fray, Poesías escogidas, Madrid, Mundo Latino, ¿1928?, 187 págs.

Lyonnet, Antoine, Le Français par les choses et par les images. Leçons de choses. Vocabulaire. Lecture et récitation. Course élémentaire $2^{\circ}$ année, Paris, Librairie Istra, 1935, 177 págs.

Machado, Antonio y Machado, Manuel, Las adelfas. Comedia en tres actos, en verso. Estrenada en el Teatro del Centro de Madrid el día 22 de octubre de 1928, dibujos de José Machado, Madrid, s.n., 1928, 98 págs. [Año II, 10 de noviembre de 1928] (Colección La Farsa, núm. 62)

Machado, Antonio, Obras completas. 1. Artículos varios, Madrid, Libreria Victoriano Suárez, Tomo 1, 1904, 112 págs.

Machado, Manuel, Apolo. Teatro pictórico, Madrid, V. Prieto y Compañía, 1911, 124 págs.

ARBOR CLXXXVI 744 julio-agosto [2010] 739-776 ISSN: 0210-1963 
Machado, Manuel, El mal poema, Madrid, Imprenta Gutenberg, 1909, 150 págs.

Machado, Manuel, Obras completas. 2. Museo Apolo, Madrid, Mundo Latino, Vol. 2, 1922, 142 págs.

Machado, Manuel, Obras completas. 3. Cante Hondo. Sevilla, Madrid, Mundo Latino, Vol. 3, 1923, 182 págs.

Machado, Manuel, Obras completas. 4. El mal poema, Madrid, Mundo Latino, Vol. 4, 1923, 182 págs.

Madariaga, Salvador de, Semblanzas literarias contemporáneas. Galdós, Ayala, Unamuno, Baroja, Valle-Inclán, Azorín, Miró, Barcelona, Cervantes, 1924, 235 págs.

Maeztu, Ramiro de, La crisis del humanismo. Los principios de autoridad, libertad y función a la luz de la guerra. Una crítica de la autoridad y de la libertad como fundamentos del Estado Moderno y un intento de basar las sociedades en el principio de función, Barcelona, Minerva, ¿1919?, 366 págs. (Colección Biblioteca de Cultura Moderna y Contemporánea)

Maïakowski, Wladimir, Le nuage dans le pantalon, traduit du russe par B. Goriély et R. Baert et suivi d'autres poèmes traduits par N. Guterman, París, Les Revues, 1930, 68 págs. (Colección Nos poètes, núm. 3)

Mallarmé, Stéphane, Igitur ou la Folie d'Elbehnon, avec un portrait gravé sur bois par Georges Aubert d'après le tableau d'Edouard Manet, París, Librairie Gallimard. Éditions de la Nouvelle Revue Française, 1925, 81 págs.

Manrique, Jorge, Cancionero, edición, prólogo y vocabulario de Agusto Cortina, Madrid, Ediciones La Lectura, 1929, 269 págs. (Colección Clásicos Castellanos, núm. 94)

Manzoni, Alessandro, Tragedias. Poesías y obras varias, trad. Federico Baráibar y Zumárraga, Madrid, Librería de la viuda de Hernando y Compañía, Tomo 1, 1891, 338 págs. (Colección Biblioteca Clásica, núm. 150)

Manzoni, Alessandro, Tragedias. Poesías y obras varias, trad. Federico Baráibar y Zumárraga, Madrid, Librería de la viuda de Hernando y Compañía, Tomo 2, 1891, 401 págs. (Colección Biblioteca Clásica, núm. 151)

Maples Arce, Manuel, Poemas Interdictos, Jalapa/República Mexicana, Ediciones de Horizonte, 1927, 85 págs.

Maples Arce, Manuel, Poèmes Interdits, trad. Edmond Vandercammen, Bruxeles, Les Cahiers du Journal, 1936, 68 págs.

Maragall, Juan, Obras completas. Elogios. Serie Castellana. Preliminar, Del amor, De la palabra, De la poesía, Del pueblo, Del teatro, De la danza, Del Vivir, De la gracia, De una tarde de agosto, Barcelona, Gustavo Gili, 1913, 186 págs.

Marañón, Gregorio, Veinticinco Años de Labor. Historia y Bibliografía de la obra del Prof. G. Marañón y del Instituto de
Patología Médica del Hospital de Madrid recogida por sus discípulos, Madrid, Espasa Calpe, 1935, 326 págs.

Mariana, Juan de, Obras del Padre Juan de Mariana, colección dispuesta y revisada, con un discurso preliminar de D. F. P. y M., Madrid, M. Rivadeneyra, Tomo 1, 1864, 534 págs. (Colección Biblioteca de Autores Españoles, núm. 30)

Mariana, Juan de, Obras del Padre Juan de Mariana. 2. Historia de España. Tratado contra los juegos públicos. Del Rey y de la institución Real, traducido nuevamente. De la alteración de la moneda y de las enfermedades de la compañía, Madrid, M. Rivadeneyra, Tomo 2, 1872, 632 págs. (Colección Biblioteca de Autores Españoles, núm. 31)

Marichalar, Antonio, Mentira desnuda. Hitos, Madrid, Espasa Calpe, 1933, 237 págs.

Marichalar, Antonio, Palma. Lectura crítica, Madrid, Gráficas Reunidas, 1923, 25 págs.

Marinello, Juan, Juventud y vejez, La Habana, Revista de Avance, 1928, 23 págs.

Marinello, Juan, Sobre la inquietud cubana, La Habana, Revista de Avance, 1930, 28 págs.

Marinetti, Filippo Tommaso, El Futurismo, trad. N. Hernández Luquero y Elías Nandino, Valencia, F. Sempere y Cía, ¿1911?, 194 págs.

Marivaux, Pierre de, Mariana. Novela, traducción y prólogo de Enrique González Fiol, Madrid, Librería y Casa editorial Hernando, Tomo 1, 1931, 398 págs. (Colección Biblioteca Clásica, núm. 259)

Marivaux, Pierre de, Mariana. Novela, traducción y prólogo de Enrique González Fiol, Madrid, Librería y Casa editorial Hernando, Tomo 2, 1931, 411 págs. (Colección Biblioteca Clásica, núm. 260)

Marquina, Eduardo, Doña María la brava. Número Homenaje a María Guerrero. Cuatro actos, en verso de Eduardo Marquina; En la muerte de María Guerrero: Epilogal, poema de Eduardo Marquina; Cómo ganó María Guerrero para España el corazón de América por Valentín de Pedro; Ocho fotografías de María Guerrero en "Doña María la Brava", ilustraciones de Masberger, Madrid, s.n., 1928, 94 págs. [Año II. 2 de febrero de 1928.] (Colección La Farsa, núm. 23)

Marsan, Eugène, Éloge de la Paresse, París, Hachette, 1927, 61 págs.

Marsan, Eugène, Passantes. Nouvelle Édition augmentée, París, Le Divan, 1923, 226 págs.

Martínez de la Rosa, Francisco, Obras Dramáticas. La viuda de Padilla, Aben Humeya y la Conjuración de Venecia, edición y adaptación de Jean Sarrailh, Madrid, Ediciones La Lectura. Espasa Calpe, 1933, 414 págs. (Colección Clásicos Castellanos, núm. 107) 
Martínez Sierra, Gregorio, La Casa de la primavera. Los romances del hogar, Las ciudades románticas, Paisajes espirituales, El mensaje de las rosas, Las horas, Madrid, Libreria de Perlado, Páez y Compañia. Sucesores de Hernando, 1907, 221 págs.

Martínez Sotomayor, José, La rueca de aire, México, Imprenta Mundial, 1930, 126 págs.

Martínez Sotomayor, José, Lentitud, México, Imprenta Mundial, 1933, 75 págs.

Maurois, André, En Amérique, s.l., Flammarion, 1933, 125 págs. [Avec quatre planches hors-texte tirées en héliogravure]

Maurois, André, Mes songes que voici, Paris, Bernard Grasset, 1933, 289 págs.

Maurras, Charles, L'avenir de l'intelligence. Suivi de Auguste Comte. Le romantisme féminin. Mademoiselle Monk, París, Nouvelle Librairie Nationale, 1917, 318 págs.

Maurras, Charles, La Musique. Intérieure, Paris, Bernard Grasset, 1925, 325 págs.

Meléndez Valdés, Juan, Poesías, edición, prólogo y notas de Pedro Salinas, Madrid, Ediciones La Lectura, 1925, 312 págs. (Colección Clásicos Castellanos, núm. 64)

Méndez Cuesta, Concha, Canciones de mar y tierra, Buenos Aires, Talleres Gráficos Argentinos L. J. Rosso, 1930, 187 págs.

Méndez Cuesta, Concha, El personaje presentido y el ángel cartero. Teatro, Madrid, Imprenta de Galo Sáez, 1931, 141 págs.

Méndez Cuesta, Concha, Surtidor: poesías, Madrid, s.n., 1928, 111 págs.

Menéndez Pidal, Ramón, Antología de prosistas españoles, Madrid, Junta para la Ampliación de Estudios. Centro de Estudios Históricos. Publicaciones de la revista de Filología Española, 1932, 381 págs.

Menéndez Pidal, Ramón, El Romancero. Teorías e investigaciones, Madrid, Editorial Páez, s.a., 229 págs. (Colección Biblioteca de Ensayos, núm. 3)

Menéndez Pidal, Ramón, Un aspecto en la elaboración del "Quijote", s.l., s.n., 1920, 54 págs. [Discurso leído en la inauguración del curso de 1920-1921 el día 1 de diciembre de 1920. Ateneo Científico, Literario y Artístico de Madrid]

Menéndez y Pelayo, Marcelino, Orígenes de la novela. 1. Introducción. Tratado histórico sobre la primitiva novela española, Madrid, Bailly Bailliére, Tomo 1, 1925, 499 págs. (Colección Los clásicos olvidados. Nueva Biblioteca de Autores Españoles, núm. 1)

Menéndez y Pelayo, Marcelino, Orígenes de la novela. 2. I. Novelas de los siglos XV y XVI, con un discurso preliminar de Marcelino Menéndez y Pelayo, Madrid, Bailly Bailliére, Tomo 2, 1931,
302 págs. [Tomo 2. Primera parte] (Colección Los clásicos olvidados. Nueva Biblioteca de Autores Españoles, núm. 7)

Menéndez y Pelayo, Marcelino, Orígenes de la Novela. 2. II. Novelas de los siglos XV y XVI, con un estudio preliminar de Marcelino Menéndez y Pelayo, Madrid, Bailly Bailliére, Tomo 2, 1931, 710 págs. [Tomo 2. Segunda parte] (Colección Los clásicos olvidados. Nueva Biblioteca de Autores Españoles, núm. 7)

Menéndez y Pelayo, Marcelino, Orígenes de la Novela. 4. "El Asno de Oro" de Lucio Apuleyo, "Eurialo e Lucrecia"; "Fabulario" de Sebastián Adey; "Coloquios" de Erasmo, "Coloquio de las damas" de Pedro Azetino, "Diálogos de Amor" de León Hebreo; "El viaje entretenido" de Agustín de Rojas, por Marcelino Menéndez y Pelayo, introducción de A. Bonilla y San Martín, Madrid, Bailly Bailliére, Tomo 4, 1915, 620 págs. (Colección Los clásicos olvidados. Nueva Biblioteca de Autores Españoles, núm. 21)

Merimée, Prosper, Colomba y otros cuentos y novelas, trad. Ángel de la Guardia, Madrid, Librería de los sucesores de Hernando, 1911, 465 págs. (Colección Biblioteca Clásica, núm. 226)

Mesa, Enrique de, Andanzas serranas. Por Somosierra y Guadarrama, Madrid, Biblioteca Renacimiento, 1910, 82 págs.

Mesa, Enrique de, Cancionero castellano, Madrid, Imprenta de P. Fernández, 1911, 124 págs.

Mesa, Enrique de, La posada y el camino. Versos, Madrid, s.n. 1928, 136 págs. (Colección Imprenta Artística)

Meurant, René, Naissance de la Revolte, Bruxelles, Les cahiers du "Journal des Poetes", 1934, 37 págs.

Millares Carlo, Agustín, Documentos pontificios en papiro de Archivos catalanes, Madrid, Imprenta Fortanet, 1918, 274 págs. [Primera parte]

Miró, Gabriel, Años y leguas, Madrid, Biblioteca Nueva, 1928, 310 págs. (Colección Obras completas de Gabriel Miró, núm. 11)

Miró, Gabriel, Del Vivir, Corpus y otros cuentos, Madrid, Biblioteca Nueva, 1927, 271 págs. (Colección Obras completas de Gabriel Miró, núm. 1)

Miró, Gabriel, Las cerezas del cementerio, Madrid, Biblioteca Nueva, 1926, 270 págs. (Colección Obras completas de Gabriel Miró, núm. 3)

Miró, Gabriel, Obras completas. 1. Del Vivir. La Novela del amigo, prolog. Azorín, s.l., Amigos de Gabriel Miró, Vol. 1, 1932, 288 págs.

Miró, Gabriel, Obras completas. 4. El abuelo del rey. Nómada prolog. Pi Suñer, Augusto, s.l., Amigos de Gabriel Miró, Vol. 4, 1933, 267 págs.

Misticos españoles, selección, prólogo y notas biográficas por Luis Santullano, Madrid, Instituto Escuela. Junta para Ampliación

ARBOR CLXXXVI 744 julio-agosto [2010] 739-776 ISSN: 0210-1963

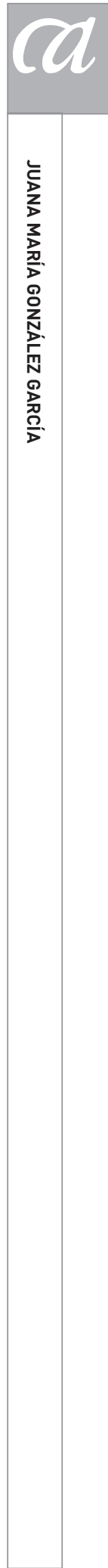


de Estudios, 1934, 214 págs. [Colección dirigida por Ramón Menédez Pidal] (Colección Biblioteca literaria del estudiante, núm. 18)

Mistral, Gabriela, Desolación. Poemas, New York, Instituto de las Españas, 1922, 248 págs.

Molina, Tirso de, Comedias de Tirso de Molina, colección e ilustraciones de Emilio Cotarelo y Mori, Madrid, Bailly Bailliére, Tomo 1, 1906, 675 págs. (Colección Los clásicos olvidados. Nueva Biblioteca de Autores Españoles, núm. 4)

Molina, Tirso de, Comedias de Tirso de Molina, colección e ilustraciones de Emilio Cotarelo y Mori, Madrid, Bailly Bailliére, Tomo 2, 1907, 742 págs. (Colección Los clásicos olvidados. Nueva Biblioteca de Autores Españoles, núm. 9)

Molinari, Ricardo E., Delta, Buenos Aires, s.n., 1932

Molinari, Ricardo E., El pez y la manzana, con un retrato del autor y dibujos por Norah Borges, Buenos Aires, Talleres Gráficos Colón, 1929, 37 págs. (Colección Cuadernos del Plata)

Moncada, Francisco de, Expedición de los catalanes y aragoneses contra turcos y griegos, prólogo y notas de Samuel Gili y Gaya, Madrid, Ediciones La Lectura, 1924, 368 págs. (Colección Clásicos Castellanos, núm. 54)

Montes, Euxenio, Versos a tres cás o neto, A Coruña, Nós, Vol. 37, 1930, 110 págs.

Montherlant, Henry de, Chant funèbre pour les morts de Verdun, Mayenne, Bernard Grasset, 1925, 135 págs.

Montherlant, Henry de, La petite Infante de Castille. Historiette, París, Bernard Grasset, 1929, 241 págs.

Montherlant, Henry de, Les bestiaires, Paris, Bernard Grasset, 1926, 298 págs.

Montoliu, Manuel de, Llenguatge i poesia. Quatre assaigs, BarceIona, Publicaciones de La Revista, 1929, 158 págs.

Montoto, Santiago, Las Delicias Viejas. Poesías, Sevilla, Tipografía Gironés, 1919, 103 págs.

Morales, Tomás, Las rosas de Hércules, Madrid, Imprenta Clásica Española, 1922, 171 págs. [Libro primero]

Morales, Tomás, Las rosas de Hércules, Madrid, Librería de Perlado, Páez y Compañia. Sucesores de Hernando, 1919, 195 págs. [Libro segundo]

Morales, Tomás, Poemas de la Gloria, del Amor y del Mar, con una poesía de Salvador Rueda, Madrid, Imprenta Gutenberg-Castro, 1908, 136 págs.

Moratín, Leandro Fernández de, Teatro, edición, prólogo y notas de F. Ruiz Morcuende, Madrid, Ediciones La Lectura, 1924, 302 págs. (Colección Clásicos Castellanos, núm. 58)

Moreno Villa, José, Colección. Poesías, Madrid, Imprenta de Caro Raggio, 1924, 113 págs.
Moreno Villa, José, El pasajero, con un ensayo de José Ortega y Gasset, Madrid, Imprenta Clásica Española, 1914, 76 págs.

Moreno Villa, José, Jacinta la pelirroja, Málaga, Imprenta Sur, 1929, 71 págs. [2 Suplemento de Litoral]

Moreno Villa, José, Patrañas. Cuentos, Madrid, Rafael Caro Raggio, 1921, 174 págs.

Moreno Villa, José, Pruebas de Nueva-York, Málaga, Imprenta Sur, 1927, 68 págs.

Moreno Villa, José, Puentes que no acaban, Madrid, Imprenta Concha Méndez y Manuel Altolaguirre, 1933, 58 págs.

Moreno-Sánchez, Manuel, Notas desde Abraham Ángel, s.l., Ediciones de Barandal, 1932, 60 págs.

Moreto, Agustín, Comedias escogidas, colección e ilustraciones de Luis Fernández Guerra-Guerra y Orbe, Madrid, M. Rivadeneyra, 1856, 654 págs. (Colección Biblioteca de Autores Españoles, núm. 39)

Morón, Antonio, Sobre la verdadera muerte del capitán araña, s.l., s.n., 1934, 29 págs.

Muñoz Rojas, José Antonio, Versos de retorno (1928), Málaga, Imprenta Sur, 1929, 75 págs.

Muñoz San Román, José, Sevilla la bienamada. Paraíso de ensueño y poesía, Sevilla, Tipografía Gómez Hermanos, 1929, 157 págs.

Musset, Alfred de, Confesión de un hijo del siglo. Novela, trad. Francisco García Ortega, Madrid, Calpe, 1923, 330 págs. (Colección Universal, núm. 841-844)

Musset, Alfred de, Los caprichos de Mariana, s.l., s.n., Tomo 10, s.a., 371 págs.

Musset, Alfred de, Los caprichos de Mariana y otras comedias, trad. Pedro Salinas, Madrid, Alberto Jiménez Fraud, Tomo 11, s.a., 371 págs. (Colección Granada)

Musset, Alfred de, Los caprichos de Mariana y otras comedias, trad. Pedro Salinas, Madrid, Alberto Jiménez Fraud, Tomo 12, s.a., 371 págs. (Colección Granada)

Nandino, Elías, Eco, México, Imprenta Mundial, 1934, 55 págs.

Navarro Tomás, Tomás, Introducción a las obras de Garcilaso, Madrid, Artes de la llustración, 1924, 63 págs. [Prólogo de la segunda edición de las obras de Garcilaso en Clásicos Castellanos, vol. 3]

Navarro Tomás, Tomás, Spanish in the talking films. El idioma español en el cine parlante, trad. Aurelio M. Espinosa, Madrid, Tipografía de Archivos, 1930, 94 págs.

Navarro y Ledesma, Francisco, El ingenioso hidalgo Miguel de Cervantes Saavedra. Sucesos de su vida contados por Francisco Navarro y Ledesma, Madrid, Sucesores de Hernando, 1905, 608 págs. 
Navarro y Ledesma, Francisco, Lecturas literarias. Ensayo de un libro para los alumnos de literatura preceptiva, Madrid, Sáenz de Jubera Hermanos, 1898, 532 págs.

Nervo, Amado, Los jardines interiores en voz baja, Madrid, Biblioteca Nueva, 1920, 237 págs. (Colección Obras completas de Amado Nervo, núm. 7)

Noguera, Vicente, Cancionero silencioso, Madrid, Imprenta Concha Méndez y Manuel Altolaguirre, 1936, 187 págs.

Noguera, Vicente, Yunque de oro, Madrid, Librería Bergua, 1934, 114 págs.

Novelistas anteriores a Cervantes, Madrid, M. Rivadeneyra, 1876, 690 págs. (Colección Biblioteca de Autores Españoles, núm. 3)

Novelistas españoles posteriores a Cervantes, con un Bosquejo histórico sobre la novela española escrito por Eustaquio Fernández de Navarrete, Madrid, M. Rivadeneyra, Tomo 2, 1871, 584 págs. (Colección Biblioteca de Autores Españoles, núm. 33)

Novelistas posteriores a Cervantes, colección revisada y precedida de una noticia critico-bibliográfica de Cayetano Rosell, Madrid, M. Rivadeneyra, Tomo 1, 1851, 586 págs. (Colección Biblioteca de Autores Españoles, núm. 18)

Nóvoa Gil, Virgilio Antonio, Silencio... Poemas, poesía-prólogo de Manuel Machado, Madrid, CIAP, 1932, 200 págs.

Núñez de Arenas, Manuel, "Don Vicente Maria Santiváñez. Un madrileño en la Revolución Francesa", en Tirada aparte de la Revista de la Biblioteca Archivo y Museo del Ayuntamiento de Madrid, Madrid, Imprenta Municipal, 1925, 25 págs.

Obras originales del Conde de Floridablanca y escritos referentes a su persona, colección e ilustraciones de Antonio Ferrer del Río, Madrid, M. Rivadeneyra, 1867, 530 págs. (Colección Biblioteca de Autores Españoles, núm. 59)

Obregón, Antonio de, Efectos navales. Novela, Madrid. Buenos Aires, CIAP. Ediciones Ulises, 1931, 158 págs. (Colección Valores actuales)

Obregón, Antonio de, El campo, la ciudad, el cielo. Poemas. 1. Llegada. Poemas en verso. 2. La vida múltiple. Poemas en prosa (192...-1930), Madrid, s.n., ¿1929?, 141 págs. [Dos decoraciones, retrato y portada de Antonio Walls]

Olagüe, Ignacio, Martín Alegret, el organero. Novela sobre un tema musical, Madrid, Talleres Espasa Calpe, 1928, 139 págs.

Oliver Belmás, Antonio, Mástil. Poesía, 1923-1925, Cartagena, Imprenta de la viuda de M. Carreño, 1925, 118 págs.

Onís, Federico de, Ensayos sobre el sentido de la cultura española, Madrid, Publicaciones de la Residencia de Estudiantes, 1932, 284 págs. [Serie 2. Vol. 18]
Onís, Federico de, Jacinto Benavente. Estudio Literario, New York, Instituto de las Españas, 1923, 72 págs.

Ontañón, Eduardo de, Cuaderno de poemas, Burgos, Ediciones Parábola, 1927, 32 págs.

Ontañón, Eduardo de, Llar. Poemas de la tierra montañesa, Burgos, Ediciones Parábola, 1923, 91 págs. [Grabados de Jaime]

Oribe, Emilio, La transfiguración del cuerpo, Buenos Aires/Montevideo, Palacio del Libro, 1930, 164 págs.

Orozco Muñoz, Francisco, iOh, tú, que comienzas a tener un pasado!... Pequeños poemas, Bruselas, Imprenta Luis DesmetVerteneuil, 1932, 51 págs.

Ortega y Gasset, José, El Espectador. Notas del vago estío, vitalidad, alma, espíritu, fraseología y sinceridad, Madrid, Revista de Occidente, Vol. 5, 1927, 209 págs.

Ortega y Gasset, José, El Espectador, Madrid, Imprenta Renacimiento, Vol. 1, 1916, 224 págs.

Ortega y Gasset, José, El Espectador. Elogio del "murciélago". Pepe Tudela vuelve a la mesta. Apatía artística. Dan Auta, cuento negro. Carta a un joven argentino que estudia filosofía. No ser hombre ejemplar. Esquema de Salomé. Temas de viaje. Las dos grandes metáforas. Conversación en el golf o la idea del dharma, Madrid, Revista de Occidente, Vol. 4, 1925, 204 págs.

Ortega y Gasset, José, El tema de nuestro tiempo. El ocaso de las revoluciones. El sentido histórico de la teoría de Einstein, Madrid, Revista de Occidente, 1928, 247 págs.

Ortega y Gasset, José, España invertebrada. Bosquejo de algunos pensamientos históricos, Madrid, La Lectura. Calpe, 1922, 170 págs.

Ortega y Gasset, José, Espíritu de la letra, Madrid, Revista de Occidente, 1927, 193 págs.

Ortega y Gasset, José, Goethe desde dentro. El punto de vista en las artes. El hombre interesante, prolog. Vela, Fernando, prólogo-conversación de Fernando Vela, Madrid, Revista de Occidente, 1933, 296 págs.

Ortega y Gasset, José, La deshumanización del arte e ideas sobre la novela, Madrid, Revista de Occidente, 1925, 170 págs.

Ortega y Gasset, José, La redención de las provincias y la decencia nacional. Artículos de 1927 y 1930, Madrid, Revista de Occidente, 1931, 217 págs.

Ortega y Gasset, José, Sobre reforma universitaria. Misión de la Universidad, Madrid, Revista de Occidente, 1930, 145 págs.

Ortega y Gasset, José, Tríptico. 1. Mirabeau o el político, Madrid, Revista de Occidente, Tomo 1, 1927, 91 págs.

Ortiz de Montellano, Bernardo, Primero sueño, México, Contemporáneos, 1932

Ortiz de Montellano, Bernardo, Red, México, Contemporáneos, 1928, 83 págs.

ARBOR CLXXXVI 744 julio-agosto [2010] 739-776 ISSN: 0210-1963 
Ortiz de Montellano, Bernardo, Sueños, 1930-1933, México, Contemporáneos, 1933, 75 págs.

Orueta, Ricardo de, Gregorio Hernández, Madrid, Saturnino Calleja, 1920, 68 págs. [Con 35 fotograbados] (Colección Popular de arte)

Ots Capdequi, José María, "El derecho de propiedad en nuestra legislación de Indias", en Anuario de Historia del Derecho español, Madrid, Tipografía de la Revista de Archivos, Tomo 2, 1925, 120 págs.

Ovidio Nasón, Publio, Las Heroidas, trad. Diego de Mexía, Madrid, Librería y Casa editorial Hernando, 1926, 383 págs. (Colección Biblioteca Clásica, núm. 76)

Ovidio Nasón, Publio, Las metamorfosis, trad. Pedro Sánchez de Viana, Madrid, Librería de los sucesores de Hernando, Tomo 2, 1923, 362 págs. (Colección Biblioteca Clásica, núm. 106) Ovidio Nasón, Publio, Obras de Ovidio. 3. Los Fastos. El Ibis. El Nogal. El Peseador, trad. Germán Salinas, Madrid, Librería y Casa editorial Hernando, Tomo 3, 1925, 337 págs. (Colección Biblioteca Clásica, núm. 253)

Owen, Gilberto, Novela como nube, México, Ediciones Ulises, 1928, 98 págs.

Pabst, Walther, "Góngoras Schöpfung in seinen gedichten Polifemo und Soledades", en Revue Hispanique, New York/ París, s.n., Tomo 80, 1930, 229 págs.

Palencia, Benjamín, Niños, con una silueta de B. P. por Juan Ramón Jiménez, Madrid, Rivadeneyra, 1923, 71 págs. (Colección Biblioteca de Índice, núm. 5)

Palma, Angélica, Uno de tantos. Novela, Madrid, Espasa Calpe, 1926, 217 págs.

Parnaso peruano, ordenado por Ventura García Calderón, BarceIona, Casa Editorial Maucci, ¿1915?, 319 págs.

Péguy, Charles, Morceaux Choisis. Poésie, avec un portrait de I'auteur par Pierre Laurens, París, Librairie Gallimard. Éditions de la Nouvelle Revue Française, 1927, 253 págs.

Pellicer, Carlos, Camino, París, Ediciones Estrella, 1929, 75 págs. Pellicer, Carlos, Hora y 20, París, París-América, 1927, 124 págs.

Peña Hinojosa, Baltasar, Miniaturas, Málaga, Imprenta Sur, 1927, 60 págs.

Pereda Valdés, Ildefonso, La guitarra de los negros, Buenos Aires. Montevideo, La Cruz del Sur y Martín Fierro, 1926, 62 págs. [Viñetas de María Clemencia]

Pérez Clotet, Pedro, A la sombra de la vida, Madrid, Literatura, 1935, 106 págs. (Colección P.E.N, núm. 9)

Pérez Clotet, Pedro, Signo del Alba, Málaga, Imprenta Sur, 1929, 82 págs.

Pérez Clotet, Pedro, Trasluz, Cádiz, Imprenta de Salvador Repeto, 1933, 127 págs. (Colección Isla)
Pérez de Ayala, Ramón, El sendero andante. Poemas. Momentos. Modo. Ditirambos. Doctrinal de visa y naturaleza, Madrid, Saturnino Calleja, 1921, 204 págs.

Pérez de Ayala, Ramón, Política y toros. Ensayos, Madrid, Casa Editorial Calleja, 1918, 290 págs.

Pérez de Ayala, Ramón, Prometeo. Luz de domingo. La caída de los limones. Novelas poemáticas de la vida española, Madrid, Imprenta Clásica Española, 1916, 232 págs.

Piéron, Henri, L'année psychologique, París, Librairie Félix Alcan, 1928, 448 págs. [Fondateurs Henry Beaunis et Alfred Binet. Publiée par Henri Piéron. Sécretaire de la Rédaction: Marcel François. Vingt-Huitième Année (1927) I.] (Colección Bibliothèque de Philosophie Contemporaine)

Píndaro, Odas de Píndaro, con carta-prólogo, traducción y notas de Ignacio Montes de Oca, Madrid, Librería de Perlado, Páez y Compañia. Sucesores de Hernando, 1924, 366 págs. (Colección Biblioteca Clásica, núm. 57)

Place, Edwin B., Manual elemental de novelística española. Bosquejo histórico de la novela corta y el cuento durante el siglo de oro. Con tablas cronológicas descriptivas de novelística desde los principios hasta 1700 por Edwin B. Place, Madrid, Libreria Victoriano Suárez, 1926, 133 págs. (Colección Biblioteca española de divulgación científica, núm. 7)

Plana, Alexandre, Antología de poetes catalans moderns, Barcelona, Societat Catalana d'Edicions, 1914, 308 págs.

Platón, La República o coloquios sobre la justicia, trad. José Tomás y García, Madrid, Librería de los sucesores de Hernando, Tomo 2, 1924, 331 págs. (Colección Biblioteca Clásica, núm. 94)

Plomonte, Germán, Árbol y Farola, Madrid, Poesía Nueva, 1934 [Viñetas de Consuelo Calzada]

Poema de Mio Cid, edición y notas de Ramón Menéndez Pidal, Madrid, La Lectura, 1913, 358 págs. (Colección Clásicos Castellanos, núm. 24)

Poema de Mio Cid. Puesto en romance vulgar y lenguaje moderno por Pedro Salinas, ed. Pedro Salinas, Madrid, Revista de Occidente, 1926, 183 págs. (Colección Musas lejanas. Mitos, cuentos, leyendas)

Poemas épicos, colección dispuesta y revisada, con un prólogo y un catálogo de Cayetano Rosell, Madrid, M. Rivadeneyra, Tomo 2, 1854, 518 págs. (Colección Biblioteca de Autores Españoles, núm. 29)

Poemas épicos, colección dispuesta y revisada, con notas biográficas y una advertencia preliminar de Cayetano Rosell, Madrid, M. Rivadeneyra, Tomo 1, 1851, 628 págs. (Colección Biblioteca de Autores Españoles, núm. 17) 
Poetas líricos de los siglos XVI y XVII, colección de Adolfo de Castro, Madrid, M. Rivadeneyra, 1857, 600 págs. (Colección Biblioteca de Autores Españoles, núm. 42)

Poetas líricos del siglo XVIII, colección e ilustraciones de Leopoldo Agusto de Cueto, Madrid, M. Rivadeneyra, Tomo 1, 1869, 488 págs. (Colección Biblioteca de Autores Españoles, núm. 61)

Poetas líricos del siglo XVIII, colección e ilustraciones de Leopoldo Augusto de Cueto, Madrid, M. Rivadeneyra, Tomo 2, 1871, 641 págs. (Colección Biblioteca de Autores Españoles, núm. 63)

Poetas líricos del siglo XVIII, colección e ilustraciones de Leopoldo Augusto de Cueto, Madrid, M. Rivadeneyra, Tomo 3, 1875, 744 págs. (Colección Biblioteca de Autores Españoles, núm. 67)

Polo de Medina, Salvador Jacinto, Obras escogidas de Salvador Jacinto Polo de Medina, estudio, edición y notas de José Maria de Cossío, Madrid, CIAP, 1931, 388 págs. [Colección dirigida por Pedro Sáinz y Rodríguez] (Colección Nueva Biblioteca de Autores Españoles. Los Clásicos olvidados, núm. 10)

Pomès, Mathilde, Absence Comblée, París, Les nourritures terrestres, 1933, 23 págs.

Pomès, Mathilde, Ferveur, París, A la jeune Parque, 1928, 113 págs. [Lettre facsímile de Paul Valéry. Frontispice de J. E. Laboureur]

Pomès, Mathilde, Goût du Matin, París, Les nourritures terrestres, 1934, 33 págs.

Pomès, Mathilde, Saisons, París, Ediciones de Poesía, 1931, 79 págs.

Porlán y Merlo, Rafael, Mundo blanco y negro, Sevilla, Imprenta Manuel Carmona, 1930, 31 págs. [Entregas publicadas por R. Porlán y Merlo. Con dos reproducciones de cuadros de Pablo Sebastián. Mayo 1930]

Porlán y Merlo, Rafael, Pirrón en Tarifa, Sevilla, Imprenta Mejías y Susillo, 1926, 37 págs. (Colección Mediodía)

Porlán y Merlo, Rafael, Primera y segunda parte de Olive Borden, Sevilla, Imprenta Manuel Carmona, 1930, 14 págs.

Prados, Emilio, Canciones del farero, Málaga, Litoral, 1926

Prados, Emilio, Tiempo. Veinte poemas en verso, Málaga, Imprenta Sur, 1925

Prados, Emilio, Vuelta. Seguimientos-Ausencias, Málaga, Imprenta Sur, 1927, 109 págs. [5º suplemento de Litoral]

Prampolini, Giacomo, Cosecha. Antología de la lírica castellana, Milan, Tipografía Pietro Vera, 1934, 115 págs.

Prévost, Marcel, Marie-des-Angoisses. Roman, París, Les Éditions de France, ¿1932?, 282 págs.

Prosistas modernos, selección de Enrique Díez Canedo, Madrid, Instituto Escuela. Junta para Ampliación de Estudios, 1934,
340 págs. [Dibujos de F. Marco] (Colección Biblioteca literaria del estudiante, núm. 4)

Proust, Marcel, A la recherche du temps perdu. 2. A l'ombre des jeunes filles en fleurs, París, Nouvelle Revue Française, Tomo 2, 1920, 250 págs.

Proust, Marcel, A la recherche du temps perdu. 4. I. Le côté de Guermantes. II. Sodome et Gomorrhe, Paris, Nouvelle Revue Française, Tomo 4, 1921, 282 págs.

Proust, Marcel, A la recherche du temps perdu. 6. La prisonnière (Sodome et Gomorrhe), Paris, Nouvelle Revue Française, Tomo 6, 1923, 280 págs.

Proust, Marcel, A la recherche du temps perdu. 7. Albertine Disparue, Paris, Librairie Gallimard. Éditions de la Nouvelle Revue Française, Tomo 7, 1925, 213 págs.

Proust, Marcel, El mundo de Guermantes. Sodoma y Gomorra. 1. Sodoma y Gomorra 2. El mundo de Guermantes, trad. José Maria Quiroga Plá, Madrid. Barcelona, Espasa Calpe, 1932, 372 págs.

Proust, Marcel, Por el camino de Swann, trad. Pedro Salinas, Madrid/Barcelona, Calpe, Vol. 1, 1920, 278 págs. (Colección Contemporánea)

Proust, Marcel, Por el camino de Swann, trad. Pedro Salinas, Madrid/Barcelona, Calpe, Vol. 2, 1920, 356 págs. (Colección Contemporánea)

Pulgar, Fernando del, Claros varones de Castilla, edición y anotación de J. Domínguez Bordona, Madrid, Ediciones La Lectura, 1923, 178 págs. (Colección Clásicos Castellanos, núm. 49)

Pulgar, Fernando del, Letras. Glosa a las coplas de Mingo Revulgo, ed. J. Domínguez Bordona, Madrid, Ediciones La Lectura, Vol. 2, 1929, 252 págs. (Colección Clásicos Castellanos, núm. 99)

Queremel, Ángel Miguel, Trayectoria. Esquema poemático en 33 estancias, Madrid, Librería de Fernando Fe, 1927

Quevedo, Francisco de, El Buscón, ed. Américo Castro, Madrid, Ediciones La Lectura, Vol. 1, 1927, 289 págs. (Colección Clásicos Castellanos, núm. 5)

Quevedo, Francisco de, Obras políticas, históricas y críticas. 1. Marco Bruto. Carta del rey D. Fernando el Católico. Mundo caduco y desvaríos de la edad. Grandes anales de quince días. Lince de Italia u zahorí español. El chitón de las tarabillas, Madrid, Librería de Perlado, Páez y Compañía. Sucesores de Hernando, Tomo 1, 1922, 382 págs. (Colección Biblioteca Clásica, núm. 176)

Quevedo, Francisco de, Obras políticas, históricas y críticas. 2. El rómulo. Carta al rey Luis XIII de Francia. Descifrase el alevoso manifiesto, etc. La rebelión de Barcelona. Memo- 
rial por el patronato de Santiago. Su espada por Santiago. Cuento de cuentos. La culta latinipatria. Perinola. Servicios del Sr. Duque de Lerma. Panegírico del rey D. Felipe IV, Madrid, Librería de Perlado, Páez y Compañía. Sucesores de Hernando, Tomo 2, 1922, 383 págs. (Colección Biblioteca Clásica, núm. 177)

Quevedo, Francisco de, Obras satíricas y festivas, Madrid, Libreria de los sucesores de Hernando, 1924, 566 págs. (Colección Biblioteca Clásica, núm. 33)

Quevedo, Francisco de, Política de Dios y gobierno de Cristo, Madrid, Librería de los sucesores de Hernando, 1919, 396 págs. (Colección Biblioteca Clásica, núm. 189)

Quincey, Tomás de, Del asesinato considerado como una de las Bellas Artes, traducción y prólogo de Diego Ruiz, Barcelona, F. Granada y Cía, 1907, 186 págs.

Quintana, Manuel José, Obras completas, Madrid, M. Rivadeneyra, 1852, 588 págs. (Colección Biblioteca de Autores Españoles, núm. 19)

Quintana, Manuel José, Vidas de los españoles célebres, Madrid, Librería de Perlado, Páez y Compañía. Sucesores de Hernando, Tomo 1, 1914, 503 págs. (Colección Biblioteca Clásica, núm. 12)

Quintana, Manuel José, Vidas de los españoles célebres, Madrid, Librería de Perlado, Páez y Compañía. Sucesores de Hernando, Tomo 2, 1914, 502 págs. (Colección Biblioteca Clásica, núm. 13)

Radiguet, Raymond, Le Bal du comte d'orgel. Roman, París, Bernard Grasset, 1924, 239 págs.

Radiguet, Raymond, Le diable au Corps. Roman, París, Bernard Grasset, 1923, 238 págs. (Colección Le Roman)

Raynal, Maurice, Anthologie de la Peinture en France de 1906 a nos jours, Paris, Éditions Montaigne, 1927, 319 págs.

Regnard, Jean François, Obras de Regnard. Comedias selectas. Viajes. La provenzal, novela. 1. El Jugador. El Regreso Inesperado. Los Menecmos o los Hermanos gemelos. El Heredero, trad. Cecilio Merino Ortiz, Madrid, Librería de los sucesores de Hernando, Tomo 1, 1912, 483 págs. (Colección Biblioteca Clásica, núm. 228)

Regnard, Jean François, Obras de Regnard. Comedias selectas. Viajes. La Provenzal, novela. 3. El Baile. Demócrito. El Distraído. La Serenata. Las Locuras amorosas, trad. Cecilio Merino Ortiz, Madrid, Librería de los sucesores de Hernando, Tomo 2, 1912, 452 págs. (Colección Biblioteca Clásica, núm. 229) Regnard, Jean François, Obras de Regnard. Comedias selectas. Viajes. La provenzal, novela. 3. Las Momias de Egipto. Esperadme sentado. Viaje a Laponia. Viaje a Normandía (carta a Artemisa). La Provenzal, trad. Cecilio Merino Ortiz, Madrid,
Librería de los sucesores de Hernando, Tomo 3, 1913, 345 págs. (Colección Biblioteca Clásica, núm. 230)

Régnier, Henri, La Sandale ailée. 1903-1905, París, Mercure de France, 1911, 211 págs.

Reverdy, Pierre, Les épaves du ciel, París, Nouvelle Revue Française, 1924, 222 págs.

Revista de estudios hispánicos, núm. 1, Río Piedras/Madrid/ Nueva York, Instituto de las Españas en los Estados Unidos, Tomo 1, enero-marzo de 1928, 123 págs. [Departamento de Estudios Hispánicos de la Universidad de Puerto Rico]

Reyes, Alfonso, Discurso por Virgilio, México, Contemporáneos, 1931

Reyes, Alfonso, El plano oblicuo. Cuentos y diálogos, Madrid, Tipografía Europa, Tomo 18, 1920, 128 págs.

Reyes, Alfonso, El suicida. Libro de ensayos, Madrid, Imprenta de M. García y G. Sáez, 1917, 183 págs.

Reyes, Alfonso, Fuga de Navidad, Buenos Aires, Viau y Zona, 1929, 35 págs. [Ilustraciones de Norah Borges de Torre]

Reyes, Alfonso, Pausa, París, s.n., 1926, 79 págs.

Reyes, Alfonso, Romances del río de enero, México, Oficinas Gráficas "Halcyon", 1933, 37 págs.

Reyes, Alfonso, Simpatías y diferencias, Madrid, Imprenta de Sucesores de E. Teodoro, 1921, 196 págs. [Segunda serie. I. Crítica. II. Historia menor]

Reyes, Alfonso, Simpatías y diferencias, Madrid, Imprenta E. Teodoro, 1921, 192 págs. [Primera Serie]

Reyes, Alfonso, Tren de ondas, 1924-1932, Río de Janeiro, Graphicas Villas Boas, 1932, 177 págs.

Reyes, Raimundo de los, Abecedario. Poesías, Murcia, Tipografía San Francisco, 1929, 80 págs.

Reyes, Raimundo de los, Poetas murcianos. Antología, prólogo de Agusto Vivero, epílogo de Mariano Ruiz Fúnes, s.l., Tipografía Patria, 1916, 304 págs.

Riera, Rafael, Pomarada asturiana. Escenas y narraciones, Madrid, Espasa Calpe, 1926, 225 págs.

Rilke, Rainer Maria, Les Cahiers de Malte Laurids Brigge, trad. Maurice Betz, París, Éditions Émile-Paul Fréres, 1926, 366 págs.

Rimbaud, Arthur, Oeuvres. Vers et proses. Revues sur les manuscrits originaux et les premières éditions mises en ordre et annotées par paterne berrichon. Poèmes retrouvés, Paris, Mercure de France, 1912, 401 págs. [Préface de Paul Claudel]

Rivadeneira, Pedro de, Obras escogidas, con una noticia de su vida y juicio crítico de sus escritos por Vicente de la Fuente, Madrid, M. Rivadeneyra, 1868, 609 págs. (Colección Biblioteca de Autores Españoles, núm. 60)

Rivas, Duque de, Romances, Madrid, Ediciones La Lectura, Vol. 1, 1912, 311 págs. (Colección Clásicos Castellanos, núm. 9) 
Rivière, Jacques, Aimée, Paris, Nouvelle Revue Française, 1922, 222 págs.

Rivière, Jacques, Études. Baudelaire, Paul Claudel, André Gide, Rameau, Bach, Franck, Wagner, Moussorgsky, Debussy, Ingres, Cézanne, Gauguin, París, Nouvelle Revue Française, 1911, 261 págs.

Roca de Togores, María Teresa, Romances del sur, Ávila, Tipografía Nicasio Medrano, 1935, 68 págs.

Rochelle, Drieu la, Le Jeune Européen, París, Librairie Gallimard. Éditions de la Nouvelle Revue Française, 1927, 208 págs.

Rochelle, Drieu la, Une Femme a sa fenêtre, París, Librairie Gallimard. Éditions de la Nouvelle Revue Française, 1929, 284 págs.

Rodó, José Enrique, El Mirador de Próspero, Barcelona, Cervantes, ¿1928?, 454 págs.

Rojas Zorrilla, Francisco de, Comedias escogidas de don Francisco de Rojas Zorrilla, colecc. Ramón de Mesonero Romanos, Madrid, M. Rivadeneyra, 1861, 602 págs. (Colección Biblioteca de Autores Españoles, núm. 54)

Rojas Zorrilla, Francisco de, Teatro, ed. F. Ruiz Morcuende, Madrid, Ediciones La Lectura. Espasa Calpe, 1931, 278 págs. (Colección Clásicos Castellanos, núm. 35)

Rojas, Ricardo, Cervantes, Buenos Aires, "La Facultad" J. Roldán y Compañía, 1935, 424 págs.

Romains, Jules, Cromedeyre-le-Vieil, Paris, Nouvelle Revue Française, 1920, 134 págs.

Romains, Jules, Europe, Paris, Nouvelle Revue Française, 1919, 85 págs.

Romancero general o colección de romances castellanos anteriores al siglo XVIII, recogidos, ordenados, clasificados y anotados por don Agustín Durán, Madrid, M. Rivadeneyra, Tomo 1, 1854, 600 págs. (Colección Biblioteca de Autores Españoles, núm. 10)

Romancero general o colección de romances castellanos anteriores al siglo XVIII, recogidos, ordenados, clasificados y anotados por don Agustín Durán, Madrid, M. Rivadeneyra, Tomo 2, 1851, 736 págs. (Colección Biblioteca de Autores Españoles, núm. 16)

Romancero. Colección de Romances Escogidos, Madrid, Imprenta de la Biblioteca Nacional Económica, Tomo 2, 1875, 239 págs. (Colección Biblioteca Nacional Económica)

Romera-Navarro, Miguel, Miguel de Unamuno. Novelista. Poeta. Ensayista. Presented to the Faculty of the graduate school of the University of Pennsylvania in partial fulfillment of the requirements for the degree of doctor of philosophy, Madrid, Sociedad General Española de Librería, 1928, 328 págs.
Romero Mendoza, Pedro, Azorín. Ensayo de crítica literaria, Madrid/Buenos Aires/Barcelona, CIAP, 1933, 202 págs.

Romero y Murube, Joaquín, Prosarios. Prosarios del pueblo y del campo, del prosario de la ciudad, otros prosarios. 1922-1924, Sevilla, Tipografía Gironés, Tomo 22, 1924, 77 págs.

Romero y Murube, Joaquín, Sombra apasionada (Colección, 192527), Sevilla, Mediodía, 1929, 103 págs. [5º suplemento de la colección "Mediodía"]

Ros de Olano, Antonio, El doctor Lañuela. Episodio, sacado de las Memorias inéditas de una tal Joséf, Madrid, Imprenta de Manuel Galiano, 1863, 284 págs.

Ros, Félix, Elogio de Narciso, Madrid, Cruz y Raya, 1934, 79 págs.

Ros, Félix, Una lágrima sobre la gaceta, Madrid, Literatura, Tomo 11, 1935, 136 págs. (Colección P.E.N, núm. 11)

Rosell y Torres, Isidoro, Índices Generales, precede una biografia del editor, escrita por su hijo, Madrid, M. Rivadeneyra, 1880, 349 págs. (Colección Biblioteca de Autores Españoles, núm. 71)

Rosselló Porcel, Bartomeu, Nou Poemes, Barcelona, s.n., 1933, 43 págs.

Rousseau, Jean Jacques, Les Confessions, édition intégrale publiée sur le texte autographe conservé a la bibliothèque de Géneve, acompagnée de variantes extraites du manuscrit de la chambre des députés, de notes et d'un index par Ad. Van Bever et suivie des rêveries du promeneur solitaire. Avec seize héliogravures hors texte, París, Les Éditions G. Crès et Cie, Vol. 2, 1927, 427 págs.

Rousseau, Jean Jacques, Les Confessions, édition intégrale publiée sur le texte autographe conservé a la bibliothèque de Genève, accompagnée de variantes extraites du manuscrit de la chambre des députés, de notes et d'un index par Ad. Van Bever et suivie des rêveries du promeneur solitaire avec seize héliogravures hors texte, París, Les Éditions G. Crès et Cie, Vol. 3, 1927, 300 págs.

Rueda, Lope de, Teatro, Madrid, Espasa Calpe, 1934, 269 págs. (Colección Clásicos Castellanos, núm. 59)

Ruiz de Alarcón y Mendoza, Juan, Comedias de don Juan Ruiz de Alarcón y Mendoza, colección de Juan Eugenio Hartzenbusch, Madrid, M. Rivadeneyra, 1866, 552 págs. (Colección Biblioteca de Autores Españoles, núm. 20)

Ruiz de Alarcón y Mendoza, Juan, La verdad sospechosa, comedia en tres actos, édition précédée d'une notice biographique et littéraire et accompagnée de notes, de variantes et des imitations de Pierre Corneille par Ed. Barry, París, Garnier Frères, 1911, 190 págs. [Collection publiée sous la direction de M. E. Mérimée]

ARBOR CLXXXVI 744 julio-agosto [2010] 739-776 ISSN: 0210-1963 
Ruiz de Alarcón y Mendoza, Juan, Los favores del mundo, ed. Pedro Henríquez Ureña, México, Cultura, 1922, 141 págs.

Ruiz Esparza, Juan Manuel, Caolin. Poemas, México, Cultura, 1931

Ruiz Esparza, Juan Manuel, Lintel. Poemas, México, Cultura, 1934, 61 págs.

Saavedra Fajardo, Diego de, República literaria, Madrid, Librería de Fernando Fe, 1918, 73 págs. (Colección Biblioteca de autores célebres)

Sabat Ercasty, Carlos, Poemas del hombre. Libro del mar, Montevideo, Talleres Gráficos de la Escuela Industrial, 1922, 91 págs.

Salaverría, José María, Retratos. Introducción. Regoyos. Baroja. Unamuno. Ortega y Gasset. Bécher. Epílogo, Madrid, Enciclopedia, 1926, 253 págs.

Salcedo Ruiz, Ángel, La Literatura Española. Resumen de historia. Crítica. 2. El Siglo de Oro, Madrid, Casa Editorial Calleja, Tomo 2, 1916, 400 págs. [Segunda edición refundida y muy aumentada. Ilustrada con profusión de retratos y reproducciones de documentos, monumentos, etc.]

Salinas, Pedro, Amor en vilo, Madrid, La tentativa poética, 1933, 36 págs.

Salinas, Pedro, La voz a ti debida, Madrid, Impresor S. Aguirre, 1933, 186 págs.

Salinas, Pedro, Razón de Amor. Poesía, Madrid, Cruz y Raya, 1936, 236 págs.

Salinas, Pedro, Seguro azar, Madrid, Revista de Occidente, 1929, 129 págs.

Salinas, Pedro, Vispera del gozo, Madrid, Revista de Occidente, 1926, 155 págs. (Colección Nova Novorum)

Salustio Crispo, Cayo, La conjuración de Catilina y la guerra de Jugurta, trad. Infante Gabriel, Madrid, Libreria de los sucesores de Hernando, 1923, 350 págs. [También está "Fragmentos de la grande historia" traducidos por Marcelino Menéndez Pelayo] (Colección Biblioteca Clásica, núm. 15)

Sancha, Justo de, Romancero y cancionero sagrados. Colección de poesías cristianas, morales y divinas sacadas de las obras de los mejores ingenios españoles, Madrid, M. Rivadeneyra, 1855, 568 págs. (Colección Biblioteca de Autores Españoles, núm. 35)

Sánchez Rivero, Ángel, Grabados de Goya, Madrid, Saturnino Calleja, 1920, 78 págs. [Con 28 fotograbados] (Colección Popular de arte)

Sánchez-Juan, Sebastià, Cua de Gall. Poemes, Barcelona, Llibreria Verdaguer, 1929, 45 págs.

Santillana, Marqués de, Canciones y decires, edición y notas de Vicente García de Diego, Madrid, Ediciones La Lectura, 1913, 288 págs. (Colección Clásicos Castellanos, núm. 18)
Sanz y Ruiz de la Peña, Nicomedes, Romancero Carnal (19351936), Barcelona, Apolo, 1936, 135 págs.

Savj-López, Paolo, Cervantes, trad. Antonio G. Solalinde, Madrid, Casa Editorial Calleja, 1917, 263 págs.

Schiller, Johann Christoph Friedrich, Obras dramáticas de Schiller, trad. Eduardo de Mier, Madrid, Libreria de los sucesores de Hernando, Tomo 3, 1914, 496 págs. (Colección Biblioteca Clásica, núm. 62)

Schiller, Johann Christoph Friedrich, Obras dramáticas de Schiller, trad. Eduardo de Mier, Madrid, Librería de Perlado, Páez y Compañía. Sucesores de Hernando, 1913, 468 págs. (Colección Biblioteca Clásica, núm. 43)

Schiller, Johann Christoph Friedrich, Poesías líricas, coleccionadas y en gran parte traducidas por Juan Luis Estelrich, Madrid, Librería de Perlado, Páez y Compañía. Sucesores de Hernando, Tomo 2, 1907, 415 págs. (Colección Biblioteca Clásica, núm. 218)

Schon, Dorothy, Apuntes y documentos nuevos para la biografía de Juan Ruiz de Alarcón y Mendoza, Madrid, Tipografía de Archivos, 1929, 95 págs.

Schwob, René, Profondeurs de l'Espagne, Paris, Bernard Grasset, 1928, 229 págs. (Colección Les cahiers verts, núm. 10)

Ségur, Comtesse de, Les Deux Nigauds, París, Hachette, 1930, 251 págs. [Illustrations de F. Lorioux]

Ségur, Comtesse de, Les malheurs de Sophie, Paris, Hachette, 1929, 248 págs. [Ouvrage illustré de 48 vignettes par $H$. Castelli]

Seignobos, Charles y Métin, Albert, Histoire Moderne 17151815, Paris, Librairie Armand Colin, 1911, 603 págs. [Cours d'histoire]

Selva, Salomón de la, El soldado desconocido, Portada de Diego Rivera, México, Cultura, 1922, 149 págs.

Shakespeare, William, Obras dramáticas de Guillermo Shakespeare, trad. Guillermo Macpherson, con un estudio preliminar de Eduardo Benot, Madrid, Librería de Perlado, Páez y Compañia. Sucesores de Hernando, Tomo 2, 1922, 351 págs. (Colección Biblioteca Clásica, núm. 81)

Shakespeare, William, Obras dramáticas de Guillermo Shakespeare, trad. Guillermo Macpherson, con un estudio preliminar de Eduardo Benot, Madrid, Librería de Perlado, Páez y Compañía. Sucesores de Hernando, Tomo 3, 1915, 416 págs. (Colección Biblioteca Clásica, núm. 85)

Shakespeare, William, Obras dramáticas de Guillermo Shakespeare, trad. Guillermo Macpherson, con un estudio preliminar de Eduardo Benot, Madrid, Librería de Perlado, Páez y Compañia. Sucesores de Hernando, Tomo 4, 1907, 375 págs. (Colección Biblioteca Clásica, núm. 102) 
Shakespeare, William, Obras dramáticas de Guillermo Shakespeare, trad. Guillermo Macpherson, con un estudio preliminar de Eduardo Benot, Madrid, Librería de Perlado, Páez y Compañia. Sucesores de Hernando, Tomo 5, 1914, 434 págs. (Colección Biblioteca Clásica, núm. 166)

Shakespeare, William, Obras dramáticas de Guillermo Shakespeare, trad. Guillermo Macpherson, con un estudio preliminar de Eduardo Benot, Madrid, Librería de Perlado, Páez y Compañia. Sucesores de Hernando, Tomo 6, 1922, 411 págs. (Colección Biblioteca Clásica, núm. 190)

Shakespeare, William, Obras dramáticas de Guillermo Shakespea$r e$, trad. Guillermo Macpherson, con un estudio preliminar de Eduardo Benot, Madrid, Librería de Perlado, Páez y Compañía. Sucesores de Hernando, Tomo 8, 1912, 392 págs. (Colección Biblioteca Clásica, núm. 201)

"Soledad=Saudade", en Nueva edición crítica de "El Ingenioso Hidalgo". Apéndice XXXV del tomo último del "Quijote", anot. Rodríguez Marín, Francisco, Madrid, s.n., 1928, 20 págs.

Sota y Aburto, Manuel de la, Pedro Ignacio, leyenda dramática en tres actos, Bilbao, Editorial Vasca, 1925, 168 págs.

Soto, Fausto, Guía de soñadores, Santiago de Chile, Letras, 1935, 152 págs. (Colección Autores Chilenos)

Souviron, José María, Antología de poetas españoles contemporáneos, 1900-1933, Santiago. Chile, Nascimiento, 1934, 347 págs.

Souviron, José María, Conjunto, Málaga, Imprenta Sur, 1928, 40 págs.

Souviron, José Maria, Fuego a bordo, Santiago. Chile, Nascimiento, 1932, 99 págs.

Starkie, Walter, Jacinto Benavente, London, Humphrey Milford. Oxford University Press, 1924, 218 págs.

Sterne, Laurence, Viaje sentimental, Madrid. Barcelona, Calpe, 1919, 182 págs. (Colección Universal, núm. 76-77)

Strachey, Lytton, Elisabeth et le Comte D'essex, trad. Jacques Heurgon, París, Librairie Gallimard. Éditions de la Nouvelle Revue Française, 1929, 288 págs. (Colección Vies des hommes illustres, núm. 41)

Strindberg, August, Cinco dramas en un acto, ed. Alejandro Rodríguez Álvarez, Madrid, CIAP. Mundo Latino, 1929, 286 págs.

Suárez de Figueroa, Christóbal, El Pasagero. Advertencias utilisimas a la vida humana, ed. Francisco Rodríguez Marín, s.l., Renacimiento, 1913, 366 págs. (Colección Obras maestras de la literatura universal)

Supervielle, Jules, Bosque sin horas (poemas). Con versiones de Pedro Salinas, Guillén, Mariano Brull y M. Altolaguirre, trad. Rafael Alberti, Madrid, Plutarco, Tomo 39, 1932, 129 págs.
Supervielle, Jules, Gravitations. Poèmes, Paris, Librairie Gallimard, 1932, 208 págs.

Synge, John M., Jinetes hacia el mar, edición y traducción de Zenobia Camprubi y Juan Ramón Jiménez, Madrid, Imprenta Fortanet, 1920, 57 págs. (Colección El jirasol y la espada, núm. 1)

Tagore, Rabindranath, La Cosecha. Poemas. Obras de Rabindranath Tagore, trad. Zenobia Camprubí, Madrid, Tipografía de Ángel Alcoy, 1918, 151 págs. [Con un poema de Juan Ramón Jiménez]

Tagore, Rabindranath, La Luna Nueva. Poemas de niños, trad. Zenobia Camprubi, Madrid, s.n., 1915, 107 págs. [Con un poema de Juan Ramón Jiménez]

Taine, Hipólito, Historia de la literatura inglesa. 2. El Renacimiento Jonson, Shakespeare, Milton, Madrid, La España Moderna, Tomo 2, 1900, 374 págs. (Colección Biblioteca de jurisprudencia, filosofía e historia)

Teatro anterior a Lope de Vega, selección de José Ramón Lomba y Pedraja, Madrid, Instituto Escuela. Junta para Ampliación de Estudios, 1924, 188 págs. [Colección dirigida por Ramón Menéndez Pidal. Dibujos de F. Marco] (Colección Biblioteca literaria del estudiante, núm. 15)

Teatro Antiguo español. Textos y Estudios. 2. Francisco de Rojas Zorrilla. Cada cual lo que le toca y la viña de Nabot, publicado por Américo Castro, Madrid, Junta para la Ampliación de Estudios. Centro de Estudios Históricos, Vol. 2, 1917, 267 págs.

Teatro antiguo español. Textos y estudios. 3. Luis Vélez de Guevara. El rey en su imaginación, publicado por J. Gómez Ocerín, Madrid, Junta para la Ampliación de Estudios. Centro de Estudios Históricos, Vol. 3, 1920, 156 págs.

Teatro escandinavo. "La señorita Julia", Augusto Strindberg; "El Balcón", Gunnar Heiberg; "El nuevo sistema", Bjoerson Boerstersen, traducción y prólogo de Cristóbal de Castro, Madrid, M. Aguilar, 1933, 157 págs.

Tenreiro, Ramón María, La esclava del Señor. Novela, Madrid, Biblioteca Nueva, 1927, 267 págs.

Teresa de Jesús, Santa, Camino de perfección. Reproducción fidelísima del autógrafo de El Escorial con las variantes del autógrafo vallisoletano, introducción de José María Aguado, Madrid, Ediciones La Lectura, Vol. 1, 1929, 195 págs. (Colección Clásicos Castellanos, núm. 98)

Teresa de Jesús, Santa, Camino de perfección. Reproducción fidelísima del autógrafo de El Escorial con las variantes del autógrafo vallisoletano. Sobre la oración evangelical del Pater noster, seguido de la relación de la fundación del convento de San José de Ávila, por el presbitero José María Aguado, Ma- 
drid, Ediciones La Lectura, Vol. 2, 1930, 254 págs. (Colección Clásicos Castellanos, núm. 100)

Teresa de Jesús, Santa, Escritos de Santa Teresa, añadidos e ilustrados por Don Vicente de la Fuente, Madrid, M. Rivadeneyra, Tomo 2, 1862, 538 págs. (Colección Biblioteca de Autores Españoles, núm. 55)

Thérive, André, Le Parnasse, París, Les oeuvres représentatives, 1929, 328 págs. [Colección dirigida por René Lalou] (Colección Le XIXe Siècle)

Thérive, André, Le retour d'Amazan ou une histoire de la Littérature Française, París, Le Livre, 1926, 388 págs. (Colección Essais et curiosités littéraires)

Thibaudet, Albert, Le liseur de romans, París, Les Éditions G. Crès et Cie, 1925, 238 págs. (Colección Essais et critiques)

Thomas, Jean, Quelques Aspects du Romantisme Contemporain, núm. 16, París, Société d'Edition "Les Belles Lettres", ¿1928?, 67 págs. [Études Françaises fondées sur l'initiative de la Société des Professeurs français en Amérique]

Toreno, Conde de, Historia del levantamiento, guerra y revolución de España, biografía por Leopoldo Augusto de Cueto, Madrid, M. Rivadeneyra, 1872, 534 págs. (Colección Biblioteca de Autores Españoles, núm. 64)

Torón, Saulo, Canciones de la orilla, prólogo de Enrique Díez Canedo, Madrid, Pueyo, 1932, 156 págs.

Torón, Saulo, El caracol encantado. Verso, 1918-1923, prólogo de Antonio Machado, Madrid, s.n., 1926, 139 págs.

Torón, Saulo, Las monedas de cobre. Con una poesía preliminar de Pedro Salinas (éstos son datos del libro), Portada del poeta Tomás Morales, Madrid, Imprenta Clásica Española, 1919, 145 págs.

Torón, Saulo, Las monedas de cobre. Poemas. Con una poesía preliminar de Pedro Salinas. Portada del poeta Tomás Morales, Madrid, Imprenta Clásica Española, 1912, 145 págs.

Torre, Claudio de la, El canto diverso, prólogo de Enrique Díez Canedo, Madrid, Imprenta Clásica Española, 1918

Torre, Josefina de la, Poemas de la isla, Las Palmas de Gran Canaria, CIAP, 1930, 92 págs.

Torre, Josefina de la, Versos y estampas, prólogo de Pedro Salinas, Málaga, Imprenta Sur, 1927, 67 págs. [Octavo suplemento de Litoral]

Torres Bodet, Jaime, Destierro, Madrid, Espasa Calpe, 1930, 130 págs.

Torres Bodet, Jaime, Estrella del día, Madrid, Espasa Calpe, 1933, 159 págs.

Torres Bodet, Jaime, La educación sentimental, Madrid, Espasa Calpe, s.a., 149 págs.
Toulet, Paul Jean, Les Contrerimes. Poèmes, París, Éditions ÉmilePaul Fréres, 1923, 155 págs.

Tour du pin, Patrice de la, La quête de joie, Paris, La tortue, 1933, 119 págs.

Turina, Joaquín, Enciclopedia abreviada de música, Madrid, Renacimiento, Tomo 2, 1917, 288 págs.

Turpin, François, Contes Inutiles, París, La Coinnaissance, 1921, 207 págs.

Un texto árabe occidental de la leyenda de Alejandro. Según el manuscrito ár. XXVII de la biblioteca de la Junta para Ampliación de Estudios, edición, traducción y estudio preliminar de Emilio García Gómez, Madrid, Instituto de Valencia de don Juan, 1929, 108 págs. [Instituto de Valencia de don Juan.

Unamuno, Miguel de, Cuaderno de la Magdalena, Santander, s.n., 1934, 29 págs.

Unamuno, Miguel de, Ensayos, Madrid, Publicaciones de la Residencia de Estudiantes, Tomo 4, 1917, 218 págs. [Serie 2. Vol. 11.]

Unamuno, Miguel de, Ensayos, Madrid, Publicaciones de la Residencia de Estudiantes, Tomo 5, 1917, 230 págs. [Serie 2. Vol. 13]

Unamuno, Miguel de, Ensayos, Madrid, Publicaciones de la Residencia de Estudiantes, Tomo 6, 1918, 244 págs. [Serie 2. Vol. 14]

Unamuno, Miguel de, Rosario de sonetos líricos, Madrid, Imprenta Española, ¿1911?, 291 págs.

Unamuno, Miguel de, Teresa, rimas de un poeta desconocido, Madrid, Renacimiento, ¿1920?, 227 págs.

Valbuena Prat, Ángel, "La escenografía de una comedia de Calderón", en Archivo Español de Arte y Arqueología, núm. 16, Madrid, s.n., 1930, 16 págs.

Valbuena Prat, Ángel, La poesía española contemporánea, Madrid. Buenos Aires, CIAP, 1930, 130 págs. (Colección Las cien obras educadoras, núm. 1)

Valbuena, Antonio de, Ripios Académicos, Madrid, La España Editorial, 1890, 264 págs.

Valdés, Alfonso de, Diálogo de Mercurio y Carón, edición y anotación de José Fernández Montesinos, Madrid, Ediciones La Lectura, Vol. 2, 1929, 278 págs. (Colección Clásicos Castellanos, núm. 96)

Valdés, Juan de, Diálogo de la lengua, edición y anotación de José Fernández Montesinos, Madrid, Ediciones La Lectura, 1928, 222 págs. (Colección Clásicos Castellanos, núm. 80)

Valera, Juan, Pepita Jiménez, edición y prólogo de Manuel Azaña, Madrid, Ediciones La Lectura, 1927, 255 págs. (Colección Clásicos Castellanos, núm. 80) 
Valerio Marcial, Marco, Epigramas, anotación y prólogo de Víctor Suárez Capalleja, traducidos en parte por Jáuregui, Argensola, Iriarte (Don Juan), Salinas, el P. Morell y otros y el resto por Victor Suárez Capalleja, Madrid, Librería de Perlado, Páez y Compañía. Sucesores de Hernando, Tomo 1, 1919, 379 págs. (Colección Biblioteca Clásica, núm. 140)

Valerio Marcial, Marco, Epigramas, anotación y prólogo de Víctor Suárez Capalleja, traducidos en parte por Jaúregui, Iriarte (Don Juan), Salinas, el P. Morell y otros y el resto por Victor Suárez Capalleja, Madrid, Librería de los sucesores de Hernando, Tomo 2, 1923, 358 págs. (Colección Biblioteca Clásica, núm. 141)

Valerio Marcial, Marco, Epigramas, anotación y prólogo de Victor Suárez Capalleja, traducidos en parte por Jáuregui, Argensola, Iriarte (Don Juan), Salinas, El P. Morell y otros y el resto por Victor Suárez Capalleja, Madrid, Librería de Perlado, Páez y Compañía. Sucesores de Hernando, Tomo 3, 1919, 363 págs. (Colección Biblioteca Clásica, núm. 144)

Valéry, Paul, Literatura, trad. Ricardo de Alcázar, México, s.n., 1933, 56 págs.

Valle-Inclán, Ramón María del, Aromas de leyenda. Versos en loor de un santo ermitaño, Madrid, Sociedad General Española de Librería, 1920, 97 págs.

Valle-Inclán, Ramón María del, La Guerra Carlista. 3. Gerifaltes de Antaño, Madrid, Librería Victoriano Suárez, Vol. 3, 1909, 252 págs.

Vandercammen, Edmond, Le sommeil du laboureur. Poemes 19301931, Bruxelles, Les cahiers du Journal des Poètes, 1932, 59 págs.

Vandercammen, Edmond, Saison du Malheur. Poèmes, Bruxelles, Editions "Les Cahiers du Journal des Poètes", 1935, 60 págs. Vando-Villar, Isaac del, La sombrilla japonesa, Madrid, Tableros, 1924

Vega, Lope de, Colección escogida de obras no dramáticas de Frey Lope Félix de Vega Carpio, por Cayetano Rosell, Madrid, M. Rivadeneyra, 1856, 568 págs. (Colección Biblioteca de Autores Españoles, núm. 38)

Vega, Lope de, Comedias, Madrid, Ediciones La Lectura. Espasa Calpe, Vol. 1, 1931, 272 págs. (Colección Clásicos Castellanos, núm. 39)

Vega, Lope de, Comedias escogidas de Frey Lope de Vega Carpio, coleccionadas por Juan Eugenio Hartzenbusch, Madrid, M. Rivadeneyra, Tomo 1, 1859, 590 págs. (Colección Biblioteca de Autores Españoles, núm. 24)

Vega, Lope de, Comedias escogidas de Frey Lope Félix de Vega Carpio, coleccionadas por Juan Eugenio Hartzenbusch, Ma- drid, M. Rivadeneyra, Tomo 3, 1857, 650 págs. (Colección Biblioteca de Autores Españoles, núm. 41)

Vega, Lope de, Comedias escogidas de Frey Lope Félix de Vega Carpio, coleccionadas por Juan Eugenio Hartzenbusch, Madrid, M. Rivadeneyra, Tomo 4, 1860, 592 págs. (Colección Biblioteca de Autores Españoles, núm. 52)

Vega, Lope de, Comedias escogidas de Frey Lope Félix de Vega Carpio, coleccionadas por Juan Eugenio Hartzenbusch, Madrid, M. Rivadeneyra, Tomo 2, 1855, 592 págs. (Colección Biblioteca de Autores Españoles, núm. 34)

Vega, Lope de, Obras de Lope de Vega. 3. Obras dramáticas, Madrid, Real Academia Española. Tipografía de la Revista de Archivos, Bibliotecas y Museos, Tomo 3, 1917, 689 págs.

Vega, Lope de, Obras de Lope de Vega. 2. Obras dramáticas, Madrid, Real Academia Española. Tipografía de la Revista de Archivos, Bibliotecas y Museos, Tomo 2, 1916, 668 págs.

Vega, Lope de, Obras de Lope de Vega. 5. Obras dramáticas, Madrid, Real Academia Española. Tipografía de la Revista de Archivos, Bibliotecas y Museos, Tomo 5, 1918, 700 págs.

Vega, Lope de, Obras de Lope de Vega. 13. Obras dramáticas, Madrid, Real Academia Española. Imprenta de Galo Saez, Tomo 13, 1930, 675 págs.

Vega, Lope de, Obras de Lope de Vega. 12. Obras dramáticas, Madrid, Real Academia Española. Sucesores de Rivadeneyra, Tomo 12, 1930, 687 págs.

Vega, Lope de, Obras de Lope de Vega. 7. Obras dramáticas, Madrid, Real Academia Española. Tipografía de Archivos, Tomo 7, 1930, 719 págs.

Vega, Lope de, Obras de Lope de Vega. 11. Obras dramáticas, Madrid, Real Academia Española. Imprenta de Galo Saez, Tomo 11, 1929, 745 págs.

Vega, Lope de, Obras de Lope de Vega. 8. Obras dramáticas, Madrid, Real Academia Española. Sucesores de Rivadeneyra, Tomo 8, 1930, 712 págs.

Vega, Lope de, Obras de Lope de Vega. 9. Obras dramáticas, Madrid, Real Academia Española. Tipografía de Archivos, Tomo 9, 1930, 763 págs.

Vega, Lope de, Obras de Lope de Vega. 4. Obras dramáticas, Madrid, Real Academia Española. Tipografía de la Revista de Archivos, Bibliotecas y Museos, Tomo 4, 1917, 730 págs.

Vega, Lope de, Obras de Lope de Vega. 6. Obras dramáticas, Madrid, Real Academia Española. Tipografía de Archivos, Tomo 6, 1928, 685 págs. 
Vega, Lope de, Obras de Lope de Vega. 10. Obras dramáticas, Madrid, Real Academia Española. Imprenta de Galo Saez, Tomo 10, 1930, 738 págs.

Vega, Lope de, Poesías líricas. 1. Primeros romances, letras para cantar, sonetos, edición, prólogo y notas de José Fernández Montesinos, Madrid, Ediciones La Lectura, Vol. 1, 1926, 296 págs. (Colección Clásicos Castellanos, núm. 68)

Vega, Lope de, Poesías líricas. Canciones, epístolas, romances, poemas diversos, edición, prólogo y notas de José Fernández Montesinos, Madrid, Ediciones La Lectura, Vol. 2, 1926, 298 págs. (Colección Clásicos Castellanos, núm. 75)

Vegué y Goldoni, Ángel, Los sonetos "Al itálico modo" de don Íñigo López de Mendoza. Marqués de Santillana. Estudio crítico y nueva edición de los mismos, Madrid, Imprenta de A. Marzo, 1911, 104 págs.

Vegué y Goldoni, Ángel, Temas de Arte y de Literatura, Madrid, Imprenta Iris, 1928, 186 págs.

Venegas, José, Los problemas del libro en lengua castellana, Madrid, Imprenta de Galo Sáez, 1931, 119 págs.

Verdaguer, Jacinto, Obres Completes. 2. Idilis y Cants Mistichs, Barcelona, Publicació de la ilustració catalana, Vol. 2, s.a., 207 págs. [Edició popular]

Verhaeren, Émile, Les Blés mouvants. Poémes, Paris, Mercure de France, 1913, 178 págs.

Verlaine, Paul, Fiestas Galantes. Romanzas sin palabras, trad. Luis Fernández Ardavín, Madrid, Mundo Latino, 1921, 180 págs. (Colección Obras completas de Paul Verlaine, núm. 4)

Verlaine, Paul, Los poetas malditos, trad. Mauricio Bacarisse, Madrid, Ediciones Mundo Latino, 1921, 199 págs. (Colección Obras completas de Paul Verlaine)

Vilallonga, Luis, Seis cuentos y uno más, Bilbao, Imprenta Alemana, 1929, 85 págs. (Colección L.V.M., núm. 2)

Villaespesa, Francisco, Julio Herrera Reissig. Poesías, Madrid, Imprenta Helénica, 1911, 107 págs. [Vida y arte de Francisco Villaespesa] (Colección Vida y arte)

Villaurrutia, Xavier, Reflejos, México, Cultura, Tomo 2, 1926, 114 págs. (Colección Biblioteca Universo, núm. 1)

Villon, François, Oeuvres, avec prèface, notices, notes et glossaire par Paul Lacroix, Paris, Ernest Flammarion, ¿1910?, 364 págs.

Virgilio Marón, Publio, Églogas y Geórgicas, trad. Félix M. Hidalgo y Miguel Antonio Caro, estudio preliminar de Marcelino Menéndez y Pelayo, Madrid, Librería de los sucesores de
Hernando, 1924, 368 págs. (Colección Biblioteca Clásica, núm. 20)

Virgilio Marón, Publio, Eneida, trad. Miguel Antonio Caro, Madrid, Librería de Perlado, Páez y Compañía. Sucesores de Hernando, Tomo 1, 1923, 309 págs. (Colección Biblioteca Clásica, núm. 9)

Virgilio Marón, Publio, Eneida, trad. Miguel Antonio Caro, Madrid, Librería de los sucesores de Hernando, Tomo 2, 1923, 357 págs. (Colección Biblioteca Clásica, núm. 10)

Von Westphalen, Emilio Adolfo, Las ínsulas extrañas, Lima, Compañia de Impresiones y Publicidad Enrique Bustamante y Ballivián, 1933

Voronca, Ilarie, Poèmes parmi les hommes, avec un portrait par Edmond Vandercammen, s.l., Editions des cahiers du "Journal des Poètes", 1934, 76 págs.

Voronca, Ilarie, Ulysse dans la cité, trad. Roger Vailland, París, Éditions du Sagittaire, 1933, 68 págs.

Vossler, Karl, Lope de Vega y su tiempo, trad. Ramón de la Serna, Madrid, Revista de Occidente, 1933, 367 págs.

Werfel, Franz, L'ami du Monde, trad. L. Charles-Baudoin, París, Librairie Stock, 1924, 96 págs.

Whitman, Walt, Poemas, trad. Armando Vasseur, Valencia, F. Sempere y Cía, ¿1909?, 220 págs.

Wilder, Thornton, El puente de San Luis Rey. Novela, traducción y prólogo de Ricardo Baeza, Madrid, España, 1930, 292 págs.

Wurmser, André, Courrier de la solitude, París, Librairie Gallimard. Éditions de la Nouvelle Revue Française, 1930, 232 págs.

Zamacois, Eduardo, El Teatro por dentro. Autores, comediantes, escenas de la vida de bastidores, etc., Barcelona-Buenos Aires, Casa Editorial Maucci, 1911, 189 págs.

Zamiatin, Eugenio, El farol y otros cuentos, trad. Tatiana Enco de Valero, Madrid, Revista de Occidente, 1927, 189 págs.

Zenner, Wally, Moradas de la pena altiva, Buenos Aires, Ediciones "Orión", 1932, 94 págs.

Zola, Émile, Le Roman expérimental. Le roman expérimental, Lettre a la jeunesse, Le naturalisme au théatre, L'argent dans la littérature, Du roman, De la critique, La republique et la littérature, Paris, G. Charpentier, 1881, 369 págs.

Zorrilla, José, Poesías, edición y anotación de Narciso Alonso Cortés, Madrid, Ediciones La Lectura, 1925, 290 págs. (Colección Clásicos Castellanos, núm. 63)

Zweig, Stefan, Casanova, trad. Alzir Hella y Olivier Bournac, París, Éditions Cictor Attinger, 1930, 183 págs. 